Survey Responses from Women Workers in Indonesia's Textile, Garment, and Footwear Industries

\section{Mari Pangestu}

Medelina K. Hendytio
Overattention to the

minimum wage may have led Indonesian firms to lower other costs, including those associated with overtime pay and safe working conditions. Indonesia's workers need to be made more aware of the rights and benefits to which they are entitled.

The World Bank

East Asia and Pacific

Country Department III Indonesia Policy and Operations Division April 1997 
Policy Research Working Paper 1755

\section{Summary findings}

Young, single, women workers dominate the laborintensive textile, clothing, and footwear industries in Indonesia. This survey interviewed 300 such workers to examine three main questions:

(1) Are firms complying with labor regulations?

(2) Are women workers aware of their legal rights with respect to wages and working conditions?

(3) Does the presence of the official labor union (SPSI) in the workplace make a difference in the implementation of labor regulations?

The survey finds that compliance with minimum wages was high -80 percent of the permanent workers earned at least the minimum wage. Compliance was also high for maternity leave and hours worked a week (forced overtime work was not a major issue). Compliance was low for overtime compensation and menstrual leave with compensation. Compliance with labor regulations was higher for large firms, higher based on length of service, and relatively higher in textiles and garments compared with footwear.

The survey finds that workers are most knowledgeable about the minimum wage rate and least knowledgeable about overtime pay. The minimum wage regulation has the highest compliance rate, while overtime pay the lowest compliance rate, by firms.

The survey also found that half the members of the official labor union thought that it had not been effective in improving their wages or working conditions. While fewer workers knew whether a collective labor agreement existed in their workplace, most of the respondents who were aware of one indicated that it resulted in improved working conditions.

This paper - a product of the Indonesia Policy and Operations Division, Country Department III, East Asia and Pacific - was written as part of a broader study of Indonesia's labor market. It was presented at a joint workshop of the Ministry of Manpower and the World Bank, "Indonesian Workers in the 21st Century: Workshop for Economic Reforms and Labor Market Restructuring for Indonesia," Jakarta, April 2-4, 1996. Copies of this paper are available free from the World Bank, 1818 H Street NW, Washington, DC 20433. Please contact Joseph Israel, room MC9-378, telephone 202-458-5117, fax 202-522-1675, Internet address jisrael@worldbank.org. April 1997.(82 pages)

The Policy Research Working Paper Series disseminates the findings of work in progress to encourage the exchange of ideas about development issues. An objective of the series is to get the findings out quickly, even if the presentations are less than fully polished. The papers carry the names of the authors and should be cited accordingly. The findings, interpretations, and conclusions expressed in this paper are entirely those of the authors. They do not necessarily represent the view of the World Bank, its Executive Directors, or the countries they represent. 


\title{
Survey Responses from Women Workers in Indonesia's Textile, Garment and Footwear Industries
}

\author{
Mari Pangestu and Medelina K. Hendytio
}

\section{Center for Strategic and International Studies, Jakarta and Consultants, World Bank}

This paper resulted from a study carried out as a cooperative effort between the World Bank and the Center for Strategic and International Studies, Jakarta. The members of the team are: Medelina K. Hendytio, Sonia Prabowo, and Mari Pangestu. The survey team was made up of members from Padjadjaran University, University of Indonesia, and CSIS. The authors would like to acknowledge the contribution of Peter Gardiner and Mayling Oey-Gardiner, particularly for data processing and input into the questionnaire design. The authors would also like to thank the Ministry of Manpower and the Ministry of Women Affairs for their support and input. Finally, we would also like to thank Listiani Sasmito and Susan Rees Lane for valuable assistance in editing the drafts of this report. 
TABLE OF CONTENTS

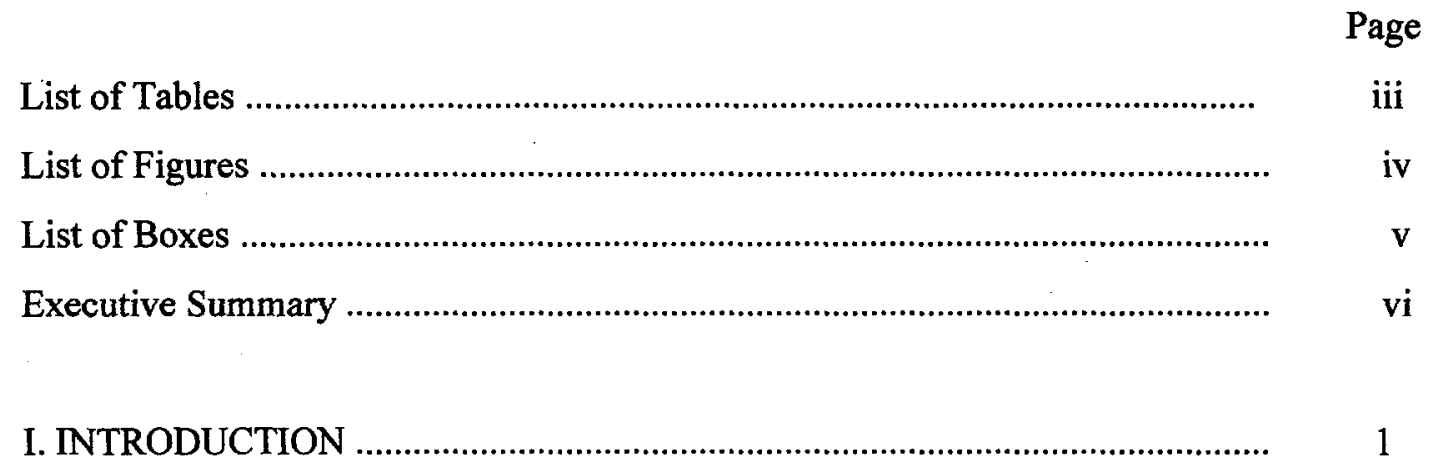

II. WOMEN WORKERS THE MAIN ISSUES ………………………………....

II.1. Characteristics of Women Workers ................................................. $\quad 8$

II.2. The Aspiration of Women Workers …………………………............ 10

II.3. Migration and Job Mobility .......................................................... 11

II.4. Women's Empowerment .................................................................. 13

III. THE GROWTH IN LABOR INTENSIVE INDUSTRIES

AND LABOR LEGISLATION …………………………........................

III.1. The Economic Climate an the Industries ...................................... 14

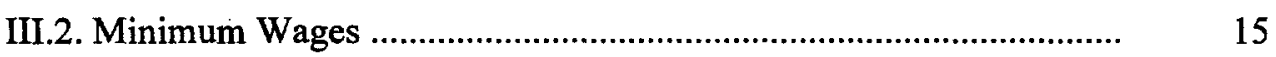

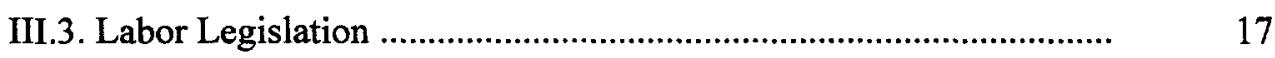

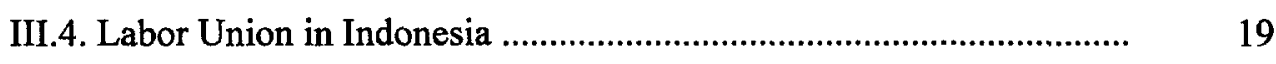

IV. DESCRIPTION OF SURVEY .................................................................

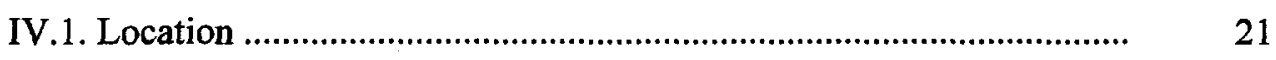

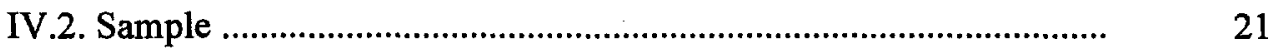

IV.3. Method of Data Gathering ........................................................... 24

V. RESULTS OF THE SURVEY .................................................................... 25

V.1. Characteristics of the Respondent ................................................... 25

V.2. Wages ......................................................................................... 27

V.3. Compliance with Labor Regulations ................................................. 31 
V.4 Health and Safety Provision ....................................................... $\quad 37$

V.5. Knowledge of Standard Working Conditions, Wages, and Benefits .. 41

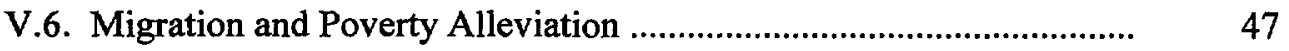

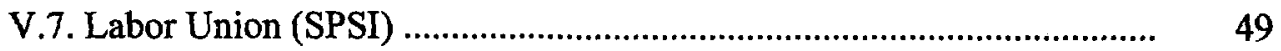

V.8. Workers' Aspirations ............................................................... 50

VI. MAIN FINDINGS AND POLICY RECOMMENDATIONS .......................... 51

VI. 1. Minimum Wages.................................................................................... 51

VI. 2. Compliance With Labor Legislation........................................................ 53

VI. 3. Health and Safety Provisions.......................................................................

VI. 4. Knowledge of Standard Working Conditions, Wages and Benefits.............. 54

VI. 5. Role of Trade Unions and Workers' Aspirations................................... 55

VII. CONCLUDING NOTES.......................................................................... 55

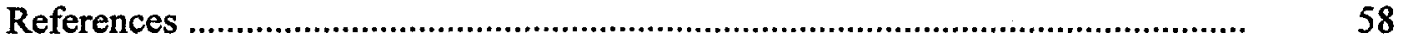

Survey of Women Workers Questionnaire …................................................. $\quad 70$ 


\section{LIST OF TABLES}

\section{Page}

Table 1

Table 2

Table 3

Table 5

Table 6

Table 7

Table 8

Table 9

Table 10

Table 11

Table 12

Table 13

Table 14

Table 15

Table 16

Table 17

Table 18

Table 19

Table 20

Table 21

Table 22

Table 23

Indonesia: Manufactured Export Classified by

Resource Intensity .............................................................. 3

Percent of Women Workers by Labor Intensive Sectors, 1993 . 4

Percent of Women Workers by Labor Intensive Sectors

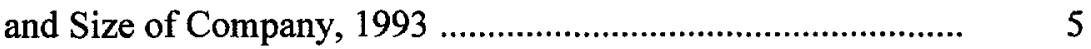

Wage Increase 1989-1994 ....................................................... 6

Sample Design ..................................................................... 23

Firms Sample by Area ...................................................... 24

Characteristics of Respondent .............................................. 25

Receipt of UMR in Relation to Company Size........................... 23

UMR in Relation of Type of Industry ....................... 28

UMR in Relation to Industry Type and Company

Scale Categories ......................... 29

UMR in Relation to length of Employment ............................. $\quad 30$

Respondents Experience of Company Compliance

With Workplace Benefits ....................................................... 33

Receipt of Entitlements in Relation To Company Size ............. 34

Receipt of Entitlements in Relation To Industry Type ............. $\quad 35$

Receipt Benefit of Entitlements in Relation to

Length of Employment ........................................................

Provision Of Facilities in Relation to Company Size Category 37

Access to Health and Safety Provisions ................................. . $\quad 38$

Use of Provided Safety Equipment .......................................... $\quad 39$

Reason For Not Using Safety Equipment ................................. $\quad 40$

Access to Safety Equipment in Relation to Company Size ...... 41

Health Problems Experienced By Respondent .......................... 41

Knowledge of Standard Working Conditions, Wages and Benefits 42

Knowledge of Entitlements in Relation to 
Company Size Category ......................................................... 43

Table $24 \quad$ Knowledge of Entitlements in Relation to Industry Type ......... 44

Table $25 \quad$ Knowledge of Entitlements in Relation to Place of Origin ....... $\quad 45$

Table $26 \quad$ Knowledge of Entitlements in Relation to Age ........................ 45

Table $27 \quad$ Knowledge of Entitlements in Relation to Education level ....... 46

Table $28 \quad$ Knowledge of Entitlements in Relation to

Length of Employment ........................................................ 46

Table 29 Saving Ability in Relation to Educational Level,

Place of Origin, and Living Arrangement ............................... $\quad 48$

Table $30 \quad$ Union Membership ..................................................................... 49

Table $31 \quad$ SPSI Membership in Relation to Company Size ........ 50 


\section{LIST OF FIGURES}

Page

Figure 1 Receipt of Entitlements in Relation to Company Size ............. 63

Figure 2 Access to Health and Safety Provisions ................................ 65

Figure 3 Access to Safety Equipment in Relation to Company Size ..... 66

Figure $4 \quad$ Knowledge of Legal Working Conditions, Wages

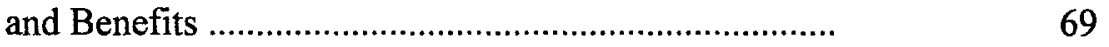

\section{LIST OF BOXES}

Box 1

The Expenses of Women Workers

Page

Box 2

Menstrual Leaves : A Hundred Ways to Get Around It

31

36 
. 


\section{EXECUTIVE SUMMARY}

i. The importance of women in economic activity has increased with their labor force participation rate increasing from 33 per cent to 39 per cent over the 1980 to 1990 period. Furthermore the highest increase, at 9 per cent per annum over the same period, was experienced by female labor force participation in the urban area. The rate of participation is expected to continue to increase reaching 44 per cent by 1998 . The increase in female participation rate can be attributed to increased employment opportunities resulting from economic growth and in particular, the outward oriented strategy followed by Indonesia since the mid 1980s which has led to rapid annual growth of manufactured exports of 29 per cent over the 1985-94 period. Growth of labor intensive exports has been higher at 34 per cent p.a. and the share of labor intensive exports has gone up from 32 per cent to 45 per cent of manufactured exports over the same period. The main labor intensive exports in Indonesia comprise of textiles, garments and footwear which together account for 37 per cent of manufactured exports and an estimated 24 per cent of the labor force in the manufacturing sector (BPS, Statistic Industry 1993). The increase in female participation, has also been due to women workers receiving better education, postponement of marriage, social mobility and changing values about women working outside the home (Manning 1993:65).

ii. Previous studies of women workers in the formal sector indicate that there is a tendency for firms in labor intensive export activities and manufacturing sectors to offer lower wages, minimum safety standards for workers and even violate worker rights. The production in such firms is characterized by mass production, utilization of standard technology, and exports are subject to intense competition. Ensuring workers' welfare and minimizing worker-employer friction, protecting and supporting workers' rights and ensuring that they work in a clean and safe environment is very important in enhancing labor productivity. Weak compliance with regulations and standards could be related to ignorance of workers about their rights, ineffectiveness of labor unions and difficulties in enforcing centrally mandated legislation and standards. Ineffectiveness of labor unions can also be related to government intervention. The latter can be caused by government regulations regarding labor unions or can be due to the effectiveness of the organization itself. Failure to ensure that workers are paid due compensation and that their safety and welfare are safeguarded, can be due to either inadequate legislation or lack of compliance by companies with regard to the labor regulations.

iii. In the Indonesian context, the issues have become increasingly important. Inadequate legislation does not appear to be the reason for poor working conditions, rather it has been due to difficulties in enforcing centrally mandated standards and lack of self regulation due in part to the absence of effective trade unions or representation of workers. The issue is also important for the sustainability and productivity of Indonesia's exports. Furthermore, the minimum wage in Indonesia has more than tripled in the 198995 period. Therefore, it is important to undertake a systematic study to understand whether firms in export oriented and labor intensive sectors are complying with 
protective legislation governing working conditions and safety. Other than the issue of workers' rights, it is also important to understand these issues of labor regulations to examine whether low worker productivity could be linked to this. As Agrawal (1995) points out, the competitiveness of Indonesia's exports is threatened by the trend of rising unit labor costs as a result of rising absolute wages and declining productivity. It is hoped that the results of the study can be used to recommend policy changes, effective implementation of policy, and introducing institutional changes.

iv. Based on the above considerations, the study is concerned with answering five main questions:

1. Are women workers receiving the legal minimum wage?

2. Are firms complying with the Indonesian government's labor legislation, standards and health and safety provisions for the protection of women workers?

3. Are women workers aware of the legal Indonesian standards of working conditions, wages and benefits?

4. Does the presence of the labor union (SPSI) in the work place strengthen the probability of implementation of labor standards, and working conditions, health and safety procedures, wages and benefits to which women workers are entitled?

5. What are the links between labor mobility of women workers in the Jakarta-West Java area and alleviation of poverty in rural and/or urban areas?

v. The survey was conducted on a sample of 300 women workers employed in a sample of firms from the three main export oriented and labor intensive sectors: textiles, garments and footwear. The choice of firms is based on output so that 85 per cent of the workers are employed in large scale and 15 per cent in medium-small enterprises. The focus is on the conditions faced by women workers, rather than all workers since the focus of this study is not on comparing pay and working conditions between female and male workers. The main characteristics of the workers surveyed are summarized in Table 7. The results of the analysis are based just on permanent workers, which make up 85 per cent of respondents.

vi. The main results with regard to compliance with minimum wage laws are as follows (Table 12). Most of the permanent workers ( 80 per cent) receive the minimum wage or higher than the minimum wage. In fact 50 per cent of workers in the large firms receive between 1-2 times the minimum wage and 2.2 per cent receive more than 2 times the minimum wage (Table 8). As expected, the percentage of permanent workers receiving below minimum wages can be found in the small-medium enterprises. In terms of the industry, a higher percentage of workers receiving below minimum wages can be found in footwear (Table 9 and Table 10). The level of basic wage is solely determined 
by the length of time the worker has worked in the factory. There is no relationship between the level of education and the basic wage as the workers surveyed are unskilled workers. Other than basic wage, 60 per cent of permanent workers receive food compensation and 30 per cent receive transportation or compensation for transport.

vii. Based on the responses from respondents, the level of compliance by firms to providing workers' benefits and facilities (Table 12) can be summarized as follows.

\section{Benefits:}

- High compliance with regard to maternity leave (96 per cent), hours worked/week (91 per cent), and maternity leave accompanied by compensation (89 per cent).

- Low compliance was found for the following benefits: breast feeding facilities (six per cent), overtime compensation (31 per cent for wage first hour, 26 per cent for wage subsequent hours) and provision of menstrual leave/compensation (37 per cent / 38 per cent ).

- The level of compliance is higher for the large firms compared with the smallmedium enterprises (SME); higher based on the length of years worked; and relatively higher for textiles and garments compared with footwear.

\section{Provision of Facilities:}

- A low number receive facilities for pregnancy checks and family planning

- A large number of respondents, 70 per cent from large firms, receive insurance and health care. Whereas in SME only 26 per cent receive insurance and 29 per cent receive health care. This is related to the better resources and capability of large firms to provide such facilities compared with SMEs.

Various issues that arise out of the above observations are: whether differentiation should be made with regard to insurance and health care facilities between large and SME; evaluation of the regulation with regard to provision of breast feeding facility since in reality it is difficult to implement; and analyzing the factors behind the low compliance for overtime compensation since 77 per cent of permanent workers work overtime and 40 per cent of respondents work more than 12 hours/week.

viii. The results of the survey with regard to ensuring a safe and healthy work place can be summarized as follows (Table 17 and Figure 3):

- Most workers have access to clean water (97 per cent), first aid (91 per cent), toilet (82 per cent) and worker training regarding the equipment and materials use in work (76 per cent).

- 60 per cent of respondents in large companies are provided with clinic facilities, and have availability doctor and nurse on site; less than 50 per cent of respondents in SME receive such facilities.

- Only 17 per cent of respondents received fire drill training. 
- Safety protection equipment was received by 64 per cent of respondents. However, the utilization rate is low and the reason given is discomfort. This implies that the provision of the equipment is not accompanied by training or awareness raising program with regard to safety in the work place.

- A large number of workers (80 per cent) indicated that they suffered from health ailments out of which 60 per cent indicated that it was due to the working environment. Even though this is the case, the level of absenteeism is low.

ix. An equally important question is with regard to workers' knowledge of their benefits and rights (Table 22 and Figure 5). The regulation that most workers are knowledgeable about is the minimum wage ( 41 per cent). Whereas, the least number of respondents indicated their knowledge with regard to breast feeding facilities and overtime compensation. Interestingly enough, these aspects have low compliance by firms. However, it cannot be concluded that in general low compliance is linked to lack of worker knowledge since there are several aspects with regard to benefits and rights where there is high compliance even though there is low level of worker knowledge. The level of worker knowledge is related to the level of education. Even though there is high compliance for the benefits and rights of workers that they are not aware of, efforts still need to be made to provide information to workers with regard to their rights.

x. In general most workers indicate that the labor union (SPSI) does not appear to be functioning optimally (Table 30). Out of 60 percent of the respondents who indicated that there was an SPSI established at their workplace, 85 per cent that they were members. However, almost half of the SPSI members indicated that their wages and benefits remain the same or unchanged. A lower number of respondents, 56 per cent, indicated that there was a Collective Labor Agreement (KKB- Kesepakatan Kerja Bersama) at their workplace, out of which only 28 per cent indicated that they understood the contents of the KKB. However, most of the respondents where there was a KKB in the work place indicated that it resulted in improvements in the working conditions.

xi. The survey also tries to address the issue of labor mobility and poverty alleviation. A large number of respondents originate from rural areas (78 per cent) and the main motivation for the single workers for migration to the urban areas is economic reasons. A significant proportion (69 per cent) repatriate their earnings to their original province and almost half indicate that they plan to return. Other than the repatriation activity in itself, it is not possible to then draw conclusions with regard to whether this alleviates poverty since the amount sent is not large ( 75 per cent of respondents indicate that they send less than Rp. 50,000 per month) and that the funds sent are used for food consumption rather than for production activity. Perhaps one use of the funds which could potentially reduce poverty is to fund the education of their siblings.

xii. The preliminary recommendations that can be put forth with regard to policy and implementation, as well as future research or studies can be summarized as follows: 
- The main finding is that the success of government stipulated regulations varies in relation to company compliance, workers' knowledge of regulations and the effectiveness of the regulations. The issue of workers' rights and the role of labor unions is also a pertinent issue raised by this research.

- Specifically, the research shows that minimum wages are more likely to be paid by large companies as opposed to small-medium sized companies. Certainly, policy issues in relation to the capacity for smaller companies to comply, whether government should regulate centrally and whether the minimum wage should be applied across all companies are raised for consideration.

- The research shows that workers experience low company compliance in regard to the provision of breast feeding facilities, menstrual leave entitlements and overtime pay rates. Again, it appears the size of the company is a relevant factor with respect to company compliance.

- Issues such as health and safety provisions for workers and workers' knowledge of standards conditions also highlight the need to further consider why larger companies appear to be more likely to comply with standards and why workers do not have adequate knowledge of safety issues and their rights and entitlements.

- The effectiveness of SPSI is highlighted, showing that further studies are required into whether more effective unionization would benefit women workers and protect their rights.

- Policy needs to take into consideration the motivations of companies to not comply with regulations. Some of these policy issues also need to acknowledge the socioeconomic vulnerability of women workers in these industries, and the subsequent likelihood of worker exploitation without effective protection for their needs, rights and entitlements.

Perhaps the strategy to black listing companies which was introduced in 1994 for non compliance regarding wages should be applied in relation to non compliance to all mandated benefits. This would assist in the development of good moral and ethical practices in Indonesian companies. 


\section{Introduction}

The importance of women in economic development has grown, with their labor force participation rate increasing from 32.7 percent to 39.2 per cent over the $1980-90$ period. It is estimated that the growth will continue so that the female participation rate will be 40.8 per cent of the labor force in 1993 and then increase to 44 per cent by 1998. The main reasons for the growth are the heightened awareness of intellectual life, the delay of marriage, increased social mobility, and the changing perception of women working outside the home (Manning 1993:65). Another factor is increased employment opportunities, especially because of growth in the laborintensive industries like textile, garment, and footwear. The growth of the above mentioned three industries has risen to 34 per cent p.a. and the share of labor intensive exports has gone up from 32 per cent to 45 per cent (see Table 1). The total number of workers in these industries (with the majority of them being women) increased sharply from 23 per cent of the total work force in the large- and mid-sized industries in 1985, to 30 per cent in 1990 (Manning 1993:65).

Recent statistics from the Industrial Survey conducted by the Central Bureau of Statistics distinguish between woman and men workers. From Table 2 it can be observed that garments and footwear are export-oriented with a significant percentage of production being exported. While the percentage of export out of production for textiles is only 18 percent, indirect exports are in fact much higher. The three sectors absorb one third of total workers. It is clear that women workers predominate in the three sectors, accounting for 45 percent of total women workers in the manufacturing sector. The three sectors, especially garment and footwear, are also dominated by women workers with three quarters of total workers being women in the garment and footwear sectors and 53 percent of total workers being women in textiles.

It is also interesting to note that most workers are in the large scale companies (Table 3). Of course the industry survey does not include the very small scale and cottage industries (defined as employing less than 20 workers). Thus, in the formal sector most workers are in the medium-large companies.

The growth of women workers in the industrial sector has a number of implications. Firstly, it means the participation of women in paid activities results in an increased strengthening of the women's position in the family and in society due to their increased financial capacity. This in turn contributes to the development of the economy. On the negative side, the participation of women in the work force corresponds with a marked deterioration in working conditions, the emergence of more low-skilled jobs and an inadequate opportunity for 
women to achieve vertical mobility. Joekes (1987) states that the growth of the industrial sector is the result of the willingness of women to work for a very low pay.

The rules and regulations set out by the government to protect the labor force, including women workers, are comprehensive. For example, Law No. 12, 1948, prohibits the use of women workers for night shift, except when the condition and the nature of the job demands otherwise. The Law No. 1, 1951 protects the rights of woman to take menstrual leave, maternity leave and have the chance to breast-feed their babies at work. In 1984, the government of Indonesia rectified the gender discrimination convention which had limited the rights of women to receive adequate medical assistance and pensions entitlements (Triaswati 1996:1). In addition, the government issued an over-time wage guideline in the Ministry decree $72 / \mathrm{Men} / 84$.

Despite the introduction of a regional minimum wage and entitlements there has been numerous cases of violations against women workers. Over the past few years there have been many cases where violators have been exposed by Non Government Organizations (NGOs). The issue of violations are two-fold. Firstly, the fact that violations against women have occurred and will continue to occur is due partly to the limited effectiveness of SPSI (All Indonesian Workers Union) to ensure implementation of labor legislation. For example, SPSI officials have a limited capacity which further prevents effective implementation of legislation (Agrawal,1995: ii). Secondly, implementation can be monitored by government officials, or by the demands of the workers to implement the rules and regulations (i.e. self regulation). In order for workers to make demands they need to have knowledge of the rules and regulations and in turn a mechanism to redress any violations. 
TABLE 1

\section{INDONESIA: MANUFACTURED EXPORTS CLASSIFIED BY RESOURCE INTENSITY}

\begin{tabular}{|c|c|c|c|c|c|c|c|c|}
\hline \multirow{3}{*}{$\begin{array}{c}\text { SITC } \\
5-8 \\
\text { (minus 68) }\end{array}$} & & & & & & 1985 & 1990 & 1994 \\
\hline & MANUFACTURING & 2,044 & 9,041 & 20,686 & 29 & 100.0 & 100.0 & 100.0 \\
\hline & $\begin{array}{l}\text { NATURAL RESOURCE } \\
\text { INTENSIVE }\end{array}$ & 993 & 3,311 & 5,073 & 20 & 48.6 & 36.6 & 24.5 \\
\hline \multirow{3}{*}{$\begin{array}{c}63 \\
66-(664- \\
666)\end{array}$} & Wood and cork manuf. & 952 & 3,065 & 4,833 & 20 & 46.6 & 33.9 & 23.4 \\
\hline & Non metalik manuf. minerals & 27 & 147 & 137 & 20 & 1.3 & 1.6 & 0.7 \\
\hline & $\begin{array}{l}\text { UNSKILLED LABOR } \\
\text { INTENSIVE }\end{array}$ & 649 & 4,092 & 9,291 & 34 & 31.8 & 45.3 & 44.9 \\
\hline 65 & Textiles, yam, fabric and prod. & 240 & 1,241 & 2,498 & 30 & 11.7 & 13.7 & 12.1 \\
\hline 84 & Garments & 339 & 1,646 & 3,206 & 28 & 16.6 & 18.2 & 15.5 \\
\hline \multirow[t]{2}{*}{85} & Footwear & 8 & 570 & 1,888 & 84 & 0.4 & 6.3 & 9.1 \\
\hline & $\begin{array}{l}\text { PHYSICAL CAPITAL } \\
\text { INTENSIVE }\end{array}$ & 102 & 405 & 1.006 & 29 & 5.0 & 4.5 & 4.9 \\
\hline 51 & Organic chemicals & 18 & 84 & 335 & 38 & 0.9 & 0.9 & 1.6 \\
\hline \multirow[t]{2}{*}{67} & Iron and Steel & 34 & 237 & 309 & 28 & 1.7 & 2.6 & 1.5 \\
\hline & HUMAN CAPITAL INTENSIVE & 99 & 666 & 2,454 & 43 & 4.8 & 7.4 & 11.9 \\
\hline 51 & Organic chemicals & 18 & 84 & 135 & 25 & 0.9 & 0.9 & 0.7 \\
\hline 64 & $\begin{array}{l}\text { Paper, paperboard and manuf. } \\
\text { thereof }\end{array}$ & 21 & 154 & 594 & 45 & 1.0 & 1.7 & 2.9 \\
\hline 69 & Manuf. of metals, nes & 1 & 112 & 328 & 95 & 0.0 & 1.2 & 1.6 \\
\hline 78 & Motor vehicles and Parts & 1 & 39 & 314 & 92 & 0.0 & 0.4 & 1.5 \\
\hline $781-783$ & Motor vehicles & 0 & 8 & 18 & 58 & 0.0 & 0.1 & 0.1 \\
\hline 784 & Motor vehicles and components & 0 & 6 & 34 & 79 & 0.0 & 0.1 & 0.2 \\
\hline \multirow[t]{2}{*}{785} & Two wheel vehicle & 0 & 25 & 243 & 103 & 0.0 & 0.3 & 1.2 \\
\hline & TECHNOLOGY INTENSIVE & 201 & 567 & 2,863 & 34 & 9.9 & 6.3 & 13.8 \\
\hline 56 & Fertilizers & 15 & 18 & 35 & 10 & 0.8 & 0.2 & 0.2 \\
\hline 752 & $\begin{array}{l}\text { Automatic data proc mach and } \\
\text { units }\end{array}$ & 0 & 0 & 96 & 154 & 0.0 & 0.0 & 0.5 \\
\hline 759 & $\begin{array}{l}\text { Parts, nes of data proc. and } \\
\text { office }\end{array}$ & 0 & 0 & 136 & 133 & 0.0 & 0.0 & 0.7 \\
\hline 76 & $\begin{array}{l}\text { Telecommunications, Video and } \\
\text { Audio }\end{array}$ & 8 & 105 & 1,472 & 79 & 0.4 & 1.2 & 7.1 \\
\hline 761 & Picture Receiver (include. radio) & 0 & 6 & 183 & 111 & 0.0 & 0.1 & 0.9 \\
\hline 762 & Sound Receiver & 0 & 37 & 269 & 136 & 0.0 & 0.4 & 1.3 \\
\hline 763 & Sound and picture recorder & 0 & 2 & 620 & - & 0.0 & 0.0 & 3.0 \\
\hline 764 & Telecomm, eq. and parts & 7 & 60 & 400 & 56 & 0.4 & 0.7 & 1.9 \\
\hline $77-775$ & $\begin{array}{l}\text { Electrical machine and app } \\
\text { (minus hhold app., elec. and non. }\end{array}$ & 73 & 97 & 579 & 26 & 3.6 & 1.1 & 2.8 \\
\hline
\end{tabular}

Source: Central Bureau of Statistics 
TABLE 2

PERCENT OF WOMEN WORKERS BY LABOR INTENSIVE SECTORS, 1993

\begin{tabular}{lrrrrrrr}
\hline & & $\begin{array}{c}\text { Export } \\
\text { Production }\end{array}$ & \multicolumn{2}{c}{ Total Works } & \multicolumn{3}{c}{ Total Women Workers } \\
\cline { 3 - 8 } & & & $\begin{array}{c}\text { No of } \\
\text { Workers }\end{array}$ & \% Dist. & $\begin{array}{c}\text { No of } \\
\text { Women } \\
\text { Workers }\end{array}$ & \% Dist. & $\begin{array}{c}\text { Women } \\
\text { Workers } \\
\text { Participati } \\
\text { on }\end{array}$ \\
\hline 1. Textile & 18.0 & 582,197 & 16.3 & 309,145 & 18.4 & 53.1 \\
2. Garment & 44.7 & 351,959 & 9.8 & 268,652 & 16.0 & 76.3 \\
3. Footwear & 75.6 & 231,135 & 6.5 & 170,918 & 10.2 & 73.9 \\
Subtotal (1-3) & 35.1 & $1,165,291$ & 32.6 & 748,715 & 44.6 & 64.3 \\
4. Food & 12.0 & 516,740 & 14.5 & 201,739 & 12.0 & 39.0 \\
$5 . \quad$ Cigarettes & 6.4 & 185,612 & 5.2 & 147,201 & 8.8 & 79.3 \\
6. Electronics & 34.9 & 107,260 & 3.0 & 55,626 & 3.3 & 51.9 \\
Subtotal (1-6) & 22.4 & $1,974,903$ & 55.3 & $1,153,281$ & 69.0 & 58.4 \\
Manufacturing & 21.6 & $3,574,809$ & 100.0 & $1,678,878$ & 100.0 & 47.0 \\
\hline
\end{tabular}

Source: BPS, Industrial Statistics, 1993 
Tabel 3

Percent of Women Workers by Labor Intensive Sectors and Size of Company, 1993

\begin{tabular}{|c|c|c|c|c|c|c|c|c|c|c|c|c|c|c|c|c|c|c|c|}
\hline & \multirow[b]{3}{*}{ - } & \multirow{2}{*}{\multicolumn{3}{|c|}{ Export Production }} & \multicolumn{6}{|c|}{$\begin{aligned} \text { Total Workers } \\
\text { No of Workers }\end{aligned}$} & \multicolumn{9}{|c|}{ Total Women Workers } \\
\hline & & & & & & o of Work & & & Distributic & & No of & Women $W$ & orkers & \multicolumn{3}{|c|}{ \% Distribution } & \multicolumn{3}{|c|}{ Women Workers } \\
\hline & & Small & Medium & Large & Small & Medium & Large & Smail & Medium & Large & Small & Medium & Large & Small & Medium & Large & Small & Medium & Large \\
\hline 1 & Textile & 6.2 & 15.3 & 19.1 & 46,314 & 125,905 & 409,978 & 9.4 & 13.4 & 19.2 & $23.95 !$ & 61,920 & 223,274 & 12.5 & 15.9 & 20.3 & 51.7 & 49.2 & 54.5 \\
\hline 2 & Garment & 17.6 & 52.1 & 45.3 & 48.907 & 91.350 & 211,702 & 9.9 & 9.7 & 9.9 & 27,722 & 66,889 & 174,041 & 14.5 & 17.2 & 15.8 & 56.7 & 73.2 & 82.2 \\
\hline \multirow[t]{2}{*}{3} & Footwear & 24.6 & 33.4 & 79.7 & 6,233 & 19,336 & 205,566 & 1.3 & 2.1 & 9.6 & 2,384 & 12,930 & 155,604 & 1.2 & 3.3 & 14.2 & 38.2 & 66.9 & 75.7 \\
\hline & Subtotal $(1-3)$ & 12.3 & 28.0 & 37.7 & 101,454 & 236,591 & 827,246 & 20.5 & 25.2 & 38.6 & 54,057 & 141,739 & 552,919 & 28.3 & 36.4 & 50.3 & 53.3 & 59.9 & 66.8 \\
\hline 4 & Food & 11.5 & 24.2 & 7.5 & 110,544 & 114,941 & 291,255 & 22.4 & 12.2 & 13.6 & 48.269 & 48,368 & 105.102 & 25.3 & 12.4 & 9.6 & 43.7 & 42.1 & 36.1 \\
\hline 5 & Clgarettes & 8.1 & 5.2 & 6.5 & 26,115 & 27,633 & 131,864 & 5.3 & 2.9 & 6.2 & 18,528 & 22,115 & 106,558 & 9.7 & 5.7 & 9.7 & 70.9 & 80.0 & 80.8 \\
\hline \multirow[t]{3}{*}{6} & Electronics & 13.0 & 27.5 & 38.3 & 8,436 & 29,582 & 69,242 & 1.7 & 3.1 & 3.2 & 2,821 & 13,820 & 38,985 & 1.5 & 3.5 & 3.5 & 33.4 & 46,7 & 56.3 \\
\hline & Subtotal (1-6) & 13.0 & 27.5 & 22.5 & 246,549 & 408,747 & $1,319,607$ & 49.9 & 43.5 & 61.7 & 123,675 & 226,042 & 803,564 & 64.7 & 58.0 & 73.2 & 50.2 & 55.3 & 60.9 \\
\hline & Manufacturing & 10.9 & 21.1 & 23.0 & 493,906 & 940,453 & $2,140,450$ & 100.0 & 100.0 & 100.0 & 191,086 & 389,534 & $1,098,258$ & 100.0 & 100.0 & 100.0 & 38.7 & 41.4 & 51.3 \\
\hline
\end{tabular}

Sourco: BPS, Industral Statistlcs, 1993 
The direct result of these frequent violations is wide-spread dissatisfaction in the work place which commonly results in worker initiated strikes. There has been an increase in the number of strikes in recent years with 1992 and 1993 being the most frequent. In 1987 there were 40 cases of strikes compared to 177 cases in 1992 and 323 in 1993. The reasons for the strikes are usually about wages and working conditions (Rinakit, 1995). Further, the mass media has reported an increase in the number of complaints made by women workers. These developments could affect the competitiveness of Indonesia's industries in the world market. Even with low-cost labor, strikes produce a reduction in working hours and therefore a decrease in productivity.

The advantage Indonesia has with one of the lowest labor-cost in Southeast Asia is reduced with a decline in labor productivity. Until the beginning of 1991, compared with other ASEAN countries, Indonesia still had a competitive edge over the other countries. However, by the end of 1992, the level of competitiveness in the manufacturing sector declined with the increase in wages and the decrease in productivity. The increase in wages was partly due to the establishment of the minimum wage standard in 1989 which increased the wage rate three-fold between 1989-1994 (Agrawal,1995).

\section{TABLE 4}

INCREASED WAGE 1989 - 1996

\begin{tabular}{|c|c|c|c|c|}
\hline Sy & 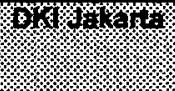 & KK & Worky & W110\% \\
\hline 1989 & 1600 & - & 1400 & - \\
\hline 1990 & 2100 & 31.25 & 1600 & 14.28 \\
\hline 1991 & 2500 & 19.04 & 2100 & 31.25 \\
\hline 1992 & 2500 & 0 & 2600 & 23.80 \\
\hline 1993 & 3000 & 20 & 2600 & $\overline{0}$ \\
\hline 1994 & 3800 & 26.66 & 3800 & 46.15 \\
\hline 1995 & 4600 & 21.05 & 4600 & 21.05 \\
\hline 1996 & 5200 & 10.63 & 5200 & 10.63 \\
\hline
\end{tabular}

Besides the impact on the competitiveness of the manufacturing industry, the deterioration of the relationship between labor and management can distort the business climate of the economy as a whole. More generally, it might discourage foreign investment, since 
foreign investment is determined not only by the cost of labor, but also by a combination of factors including the investment climate of the country, favorable exchange rates, stable macroeconomic conditions, sound infrastructure, a sophisticated banking system and a healthy relationship between workers and management.

A thorough and comprehensive understanding of women workers in Indonesia is limited by the paucity and limitations of research in this area. This study undertaken by CSIS, in cooperation with the Department of Labor and the World Bank, attempts to rectify the situation by undertaking a study with a relatively large sample, and including a broad perspective of the situation. The survey was done between August 1995 and March 1996 and the purpose of the survey was to identify the problems faced by women workers and to indicate where attention should be focused to rectify identified problems. It is important to get an accurate picture in order to recommend policy changes, ensure effective implementation of policy and to introduce broader institutional changes.

This study was undertaken based on a survey of women workers who were asked to respond to questions revolving around the following general themes:

1. Are women workers receiving the legal minimum wage?

2. Are firms complying with Government of Indonesia labor legislation, standards and health and safety provisions for the protection of women workers?

3. Are women workers aware of the legal Indonesian standards of working conditions, wages and benefits?

4. Does the presence of the official labor union (SPSI) in a workplace make a difference in the implementation of the labor standards, working conditions, health and safety procedures, wages and benefits, to which women workers are entitled?

5. What are the links between women's labor market mobility in the Jakarta-West Java region, and poverty alleviation in rural and/or urban areas?

The remainder of the paper is divided into five sections. The next two sections analyze the issues faced by women workers, the growth of labor intensive industries and the labor legislation and institutional situation for women. In the fourth section a description of the survey used in this study is provided. The findings and recommendations are then discussed in the final section. 


\section{Women Workers : The Main Issues}

Before an analysis can be undertaken, one must understand the characteristics and aspirations of the respondent group. Furthermore, it is important to understand the issue of labor mobility. Finally the concept of empowerment and how it is important for ensuring worker rights needs to be discussed.

\section{II.1 Characteristics of Women Workers}

Social characteristics as well as individual characteristics influence the level of participation of women in the work force. Individual characteristics include level of education, age, and marital status (Bukit and Bakir, 1994). The above factors not only determine the participation of women in the sectors relevant to this research but also in the informal sectors. White (1991) explains that the purpose of such information is to determine who works in these sectors, where they are from, why they work in a factory, and why they are recruited as good employees.

The combination of age, education and marital status, according to a study on gender marginalization and rural industries done by Grijns (1992), determines the stage of their life cycle that women are in, which in turn affects their labor participation and social mobility. The different and distinct phases of women's lives are: young and single women; married, divorced or widowed with young children; women with adult children (married, divorced or widowed); and older women without husband and children. Women in the first and the two last categories are more likely to join the work force since their domestic condition allows them to work outside the home without taking too much time away from their housework. Nevertheless, a divorced or widowed woman even with small children will have to work to support the family. This can only be done if the woman receives some help from other members of the family to take care of the children.

The women workers surveyed in textile, garment, and footwear industries in previous studies have the following characteristics: $75-85$ per cent of the women workers are between the ages of 15-43 years old and are single (Lok 1993, Indraswari 1995, Singarimbun 1995). Women in this age group are typically in good physical condition and will therefore have higher productivity. In terms of compensation, an unmarried woman will incur less cost to the company 
than a married woman since the companies do not have to give maternity benefits. In practice however, the savings in maternity benefits is not a major incentive in the hiring of single women. More generally, the major incentive in hiring women is that they receive lower wages compared with men. The cost of hiring women workers is only 5-8 per cent of the total cost of production compared with 10-15 per cent for men workers (Indrasari, 1991). There is also an apparent difference in the hiring pattern of married women in the textile industry and the footwear and garment industries, with 50 per cent more married women in the textile industry compared to the other two industries (Indraswari, 1995).

The level of education of women working in the footwear and textile industries is found to be higher compared to the garment industry (Indraswari, 1995). According to White (1993), the majority of women in the textile and footwear industries are high school graduates whilst in the garment industry they are mostly grade school or junior high school graduates. These findings are consistent with Lok (1993) who finds that 82 per cent of women working in the garment industry only have grade school education. These studies, however, do not offer an explanation for the discrepancy between industries. Furthermore, the minimum level of education of workers required by companies has changed. Some employers are now demanding a minimum level of junior high school education for their workers since better educated workers are seen to be more disciplined. Companies can afford to be selective since there is a labor surplus at the unskilled level.

The higher level of education among women in the footwear industry indicates that they do not come from the poorest segment of the population in the poor villages. They come from families that at least can afford to put their children through school beyond the compulsory level. With higher level education it is hoped that the daughter will get a better job than in the agricultural sector, which is considered hard manual labor (White 1993). It is time to change our views that women workers in Indonesia have a low level of education. Oey-Gardiner (1993) also points out that the better level of education among women workers implies that it will be easier to improve their skills though training. The increase in the level of education creates an opportunity for them to adapt to changing technology. Therefore, it is valuable for companies hiring women workers, in light of the changing education level, to invest in training. Better trained workers lead to increased productivity and the increase will raise the level of labor productivity in Indonesia compared to other countries. 


\section{II.2 The Aspirations of Women Workers}

An understanding of the aspirations and motivation of women workers is important because it is linked to what inspires them to act and create or be productive. This in turn affects their attitudes toward work in the industrial sector and in the workplace generally.

Aspiration is determined by social factors including cultural influences, education, and the norms adopted by the community. The value, position and role of women accepted by the community will influence women's aspirations within that community. This aspiration is in turn reflected by the kind of job chosen, perception of the job, and the woman's attitude towards the job. Grijn (1992) agrees by adding that the opportunity for women to work in the rural areas of West Java is influenced by the culture and religion. The change in views about women working outside the home makes it possible for women to have aspirations for self-improvement and financial independence. From Poerwandani's analysis (1995), the aspiration or motivation for women to work is to be independent financially as well as to personally better themselves. She found that the aspirations of young women concludes that work and independence are the strongest goals. In that survey, work and career are differentiated. For some of the respondents, their aspiration is simply to work and get economic compensation without further aspirations of getting a better position or realizing their full potential. According to Danzinger (1983) this is because women perceive barriers for advancement in line with their limited education. Aswatini (1986) also points out that women realize their limited education and minimal opportunity to work anywhere else, and thereby see work in factories as a good alternative. They do not see working in the factories as low-level-manual-labor. In fact 82 per cent of the workers surveyed state that working in the factory provides them with a better status than being a housewife. A wider implication is that as the aspirations of these women are met, they may not complain about their work conditions, nor be as aware of violations against their rights as workers. Young women fresh out of school are happy simply getting paid, however small, and overlook that they may have to work long hours to receive it. With their earnings they become more independent and less reliant on their parents. Handayani's (1995) in-depth study of two women in the textile industry concludes that the women are happy working since they develop many friendships and communicate freely among themselves. Further, the women are happy because work means they do not have to get married at a very young age. In recent times, moving out of rural areas to the cities is considered something to be proud of and a statement of a way of life. 
Since the aspirations of the women workers is simply to get paid and be independent they can also become passive in facing classic problems of labor, such as low pay, bad working conditions and not receiving their rights such as maternity leave, menstrual leave and so on. These women typically do not make the effort to find out about their rights, let alone to fight for their rights. In research conducted in Central Java, Wolf (1982:6) finds that women workers are often unaware of labor legislation and their rights and are reluctant to create conflicts. The situation is made worse by a lower level of education and lack of adequate mechanisms to provide necessary information. The passive attitude of women workers continues to contribute to their general reluctance to form a union (United Nation 1995). According to Scott (1986) the observation that women are at the bottom of the job structure indicates a marginalization process. In a broad context, marginalization is defined as a shift in power away from a party until it loses access to land, water, investment, work, education etc. to another party which will have a monopoly of these resources. Women are more likely to experience marginalization even though it is not exclusively a female phenomenon (Grijn, 1993). For women workers marginalization ensures them less chance to work, and less than adequate job related services, including health benefits. According to Scott (1986), lack of ambition is only one of the contributing factors to marginalization, and the main factor is the whole process of supply side industrial capitalism.

\section{II.3 Migration and Job Mobility}

Migration is an important indicator of the availability of work in an area. In general, the steady move of people from the rural areas to the city is an indication of economic growth (Boserup 1970:174). A survey of migration in Indonesia has concluded that migration has been dominated by men and that women are either following their husband or are avoiding economic hardship in their home town (Khoo, 1986:6). However, it has also been noted that there is an inclination for women to move to another place, especially to Jakarta, by themselves. Hugo (1989:215) finds that there are more women moving to Jakarta than men, whereas the traditional pattern of more men than women migration prevails in Lampung.

Several studies indicate that the majority of migrants are young, between the ages of 15 25 years old (Todaro 1976). This general trend probably holds true for Indonesia as indicated by a survey on the pattern of migration to Pasar Rebo district in Jakarta, 28 per cent of the people are 15-19 years old (Aswatini 1986). People who are not married are also more inclined to move 
since they have no family responsibility, and their move will be inexpensive since they do not have many belongings to transport. DeYong (1981:18), using the concept of gravitation, indicates that the place of origin, the intended place, and the distance between them are important factors in determining the level of migration. They are especially true for the workers who are categorized as nglaju or nginep. Nglaju means they work outside their area for 6-24 hours and go back to their homes, while nginep means they work away from their home town for more than one day but not for the long haul. Besides the distance, the cost is another important consideration for a migrant candidate. However, Stoufer (1960), as cited by Aswatini (1986) believes that distance has nothing to do with the volume of migration. Migration is a function of the opportunities, and the wage rates of a certain area. The irrelevance of distance can be seen in the close ties still prevailing between the migrant worker and the members of his/her family. The individuals who move far still write letters, send money home, and even visit their home town. The continued family relation has become the standard pattern seen in migration, in fact, for some communities, migration is recommended but visiting home is mandatory. Mantra (1981) gives an example of the Javanese who are reluctant to leave their birthplace even during hard economic times. Several reports point out the pull and push factors of migration for women. McGee (1971) and Boserup (1970) identify that push factors, such as limited employment opportunities and lower wages, are generally stronger for women in rural areas. Thadani and Todaro (1978:16) point out that in developing countries, the migration pattern for women is determined both by economic circumstances and cultural disapproval. Furthermore, they observe that the decision to move is also determined by the woman's views on marriage and her aspiration to find a husband. The motivation to assist with improving the family economic situation is the reason most migrants send money home. In Indonesia's case, Hugo found 81.1 per cent send some money back for their family (1989:241). Furthermore, Indrasari (1991) concludes that almost all of the respondents sent money home as a token of appreciation and respect. The spread of wealth is a positive aspect of migration and of urbanization. Migration is placing people from abundant labor, low productivity areas (agriculture) in to high productivity areas in modern cities (Woods 1982:303). The standard of living and the well being of the people in the rural areas can be increased from the money sent home by the family member who migrated. 
As a result, however, the flow of people from low productive areas to high productive areas is seen as a burden on the high productive areas. The areas have to provide living space and facilities for the migrant workers, often resulting in the growth of shanty towns.

For investors, the migration of women to the cities is very profitable. Indrasari (1991) explains that employers prefer workers from rural areas because they are not demanding, can be easily controlled, and are not distracted by family responsibilities. Women workers in this situation rarely take days off since they do not have any social obligations like religious ceremonies, family gatherings, funerals, etc.

\section{II.4. Women's Empowerment}

The fact that there is an increasing number of women workers does not alter the perception that they face poor working conditions. The level of women's education compared to their male counterparts, lower wages, and the lack of skills needed to advance, are further evidence that the condition for women in the work place is worsening. Friedmann (1996:110) believes that it is a structural issue. For instance, patriarchal culture, gender identity and women's reproductive system have all contributed to placing them in a dependent position in the home, as well as in the work place. Oakley and Marsden (1984) point out that to overcome such a situation, empowerment is needed. The empowerment process gives strength to individuals and thus provide the ability to develop skills and independence. The inability of women workers to place more effective demands on employers to comply with labor legislation is one of the reasons for inadequate working conditions. In some cases, however, no matter how empowered workers are, their demands for better working conditions are ignored. In these situations workers who make demands are often retrenched. This serves as a disincentive for other workers to make demands for change. Union representation could assist workers to address problems in the workplace, even though the existence of a union is not a guarantee that the worker can be protected and supported.

Freire (1972), on the other hand, looks at the process of empowerment as a method of changing perception, in order to allow the individual to adapt to or change the environment. In other words, in order to change the situation faced by women, the realization has to come from the women themselves. Their realization and capability is closely related to their level of education, skills, and accessibility to information. Friedmann (1996:113) disagrees, citing the 
importance of social and political empowerment along with psychological empowerment. Women have to work together to evaluate their strength and improve their conditions. Getting involved in a workers' organization is a way of empowering women psychologically, socially and politically. Self-empowerment is a less important factor in the empowerment process, because personally empowered women already realize what it takes to improve their lives. These women need a political process to assist them to make changes. The empowerment process can be recognized and reflected in policies. Molyneux (1985) views the approach as a strategic endeavor. The improvement can only be rectified by changing the social institutions that do not benefit women. Policies that guarantee equal rights and abolish discrimination against women workers will contribute to the improvement of their working conditions. This is in line with the long-term structural transformation that ensures further involvement of women in the economy, which in turn will improve the well being of the society in general.

\section{The Growth in Labor Intensive Industries and Labor Legislation}

\section{III.1. The Economic Climate and the Industries}

The increase in the number of women workers in the manufacturing industry started with efforts by government to deregulate and reform the economy in the mid 1980's as oil prices declined. The reforms were aimed at restructuring the economy by increasing the export of nonoil and gas industries. The decline in protection, relaxation of restrictions on foreign investment, especially export oriented ones, and the devaluation of the Rupiah in 1986, substantially improved the investment climate in Indonesia. As a result, there was an influx of foreign investment to Indonesia with the NIEs of Asia (Hong Kong, Singapore, Taiwan, China and South Korea) as the dominant investors. For example, in 1990, from 432 approved foreign investment projects for non-oil and gas industries, 58 per cent originated from these countries. The majority of the products were export oriented and produced with low technology, and were labor intensive. Out of 102 of the approved projects from South Korea, 99 of them were labor intensive, and 94 out of 97 projects from Taiwan were labor intensive. As is well known, the outward flows of investment from Japan and subsequently Taiwan and Korea in the late 1980's 
were undertaken in response to appreciation in their currencies and rising labor costs (as well as labor unrest in the case of Korea).

Wie (1991:58) identifies the determining factors regarding foreign investment in Indonesia. Beyond the incentives and benefits put forward by the government, low wage rates are a determining factor for investing in Indonesia

The attitude of foreign companies toward their (female) employees are said to differ from the way a local company would treat their workers. Pearson and Elson (in Minj 1995:10) state that the revenue of multi-nationals are usually higher than national companies, but generally quite unstable. Furthermore, in many of the foot loose industries such as garments and footwear, where the motivation for investment is solely low labor cost, they could move out of Indonesia at any time. Hill (1991:94) also points out that usually foreign companies have the reputation of giving their workers sub-standard living and working conditions and limited career advancement. However, these conditions are tolerated, since they are relatively better for workers than employment in the informal and agricultural sectors, where the demand for work exceeds supply. According to Hayzer (1988:10) the correlation between circumstances faced by workers in industries, and the government's strategy in the industrial sectors cannot be overlooked. Thus, there is a need to consider not just the quantity, but the quality of jobs. The improvement in working conditions is just as important as the creation of jobs. Furthermore, the nature of the jobs created by these industries is manual and repetitive work requiring minimal skills. This makes the employee more replaceable and therefore with little bargaining power.

Increasingly the industry will need to undertake work that requires skilled workers, and in turn productivity will depend on the quality of the work pool and their training. With this changing economic situation, adopting a job creation strategy which does not consider the quality of work and skills of workers will become irrelevant. To ensure the continuation of foreign investment, Indonesia has to improve its technological capability, the quality of workers, physical infrastructure and the supporting industries.

\section{III.2 Minimum Wages}

An important concept which needs to be considered when analyzing working conditions is the issue of pay. Wages are the most effective motivational instrument for women workers participating in paid activities. The relevance of pay as an important element of work conditions 
can be illustrated in the frequency of pay-related strikes. From all the recorded strikes in 1987, 32 per cent were pay related. In 1994, 61 per cent were pay related. The difference in perception between workers and management of 'fairness' and 'equity' is usually the cause of conflicts.

The market for labor is determined by the supply and demand for labor. This in turn determines wage rates, macroeconomic conditions and affects other related industries. The difference in wages is not only seen between the different sectors of the industries, but in all aspects of society. For example, the wage rates of women in industrial sectors and agricultural sectors are on average much lower compared to men's wages (Triaswati. 1996:7). For the same work, children receive less pay than adults.

Policies on regional minimum wage (Upah Minimum Regional--UMR) introduced in 1989 aim to increase minimum pay gradually. UMR is the minimum basic pay allowed for a specific area or province and is intended as a 'safety net' for workers to ensure they do not receive an extremely low pay. The 'safety net' amount is set without distinguishing between the type of job or the sector. In 1995 the UMR was above Kebutuhan Fisik Minimum (KFM) or basic physical needs. Nevertheless UMR is only 90.7 per cent of Kebutuhan Hidup Minimum (KHM) or minimum basic needs. An increase of UMR by 10.63 percent on 1 April 1996 meant that UMR is now 92.42 per cent of the minimum basic needs value. The Minister of Manpower announces that UMR will be increased every year to reach 100 per cent of KHM by 1998 . Friedman (1991) states that the objective of the UMR is the redistribution of resources in an attempt to improve the standard of living. Other motives are to increase purchasing power, to reduce poverty, to prevent worker's dissatisfaction and to improve growth and stability.

Any adjustment to the UMR should be considered carefully, since it is related to the demand for labor. It is important to consider its impact on the institutional factors and the economic climate, to ensure that a linear relationship between the labor market and the economy achieves greater efficiency and complimentary benefits. Furthermore, the changes in UMR should be preceded by an analysis on how it would impact future job creation, as well as on the informal sector.

The implication of UMR in economic terms is that there will be an increase in the costper-unit measures and eventually decrease the competitiveness of Indonesian companies (Agrawal, 1995;18-19). Secondly, UMR determined for the industrial sector will have an impact on the overall wage rate. Further, there will be concerns regarding increases in unemployment and inflation. The increase in the cost of labor might lead to down sizing of companies, or to a 
situation where workers are replaced with machinery. If there is an increase in the cost of production, the profit of the companies will be reduced. Profit is an incentive for new producers to invest in the economy. With the reduction of new producers, there will be a decrease in job creation (Starr, 1981:156). The UMR strategy is usually seen as necessary to increase pay to a substantial level, however, the informal sectors have not been considered. As for being an instrument to reduce poverty, it is not necessarily an effective one. Furthermore, it creates a division between the cities (which have a high concentration of formal sectors, and the rural areas with a high concentration of informal sectors and the agricultural sector). Despite the above considerations, the Indonesian government continues to pursue a minimum wage policy which has led to substantial increases in the last few years. It has been at the forefront of discussion about labor.

UMR in Indonesia is for all sectors in the economy regardless of type or scale of industry. It is also necessary to remember minimum wage rate must be implemented by all companies and as can be expected the large-scale companies are more likely to comply. However the standard of living can not be measured merely by salary. Other benefits such as health insurance, and pension funds, need to be considered. The amount and type of benefits given are some indication of the ability of the companies to comply with requirements (ILO, 1992:24). It is important to view the total package of salary and benefits in order to evaluate what has been received. Large companies usually comply with the regulations but are unlikely to add anything else above the regularized amount set by the government. Small sized companies are usually unable to comply with the regulation but would add to the basic salary informally.

\section{III.3. Labor Legislation}

Labor legislation establishes workers' basic rights, the reality of which has significant influence on workers' bargaining power. Generous statutory rights in Indonesia have been established since the early 1950s. They include a 40 -hour working week, rest period of $1 / 2$ hour after working 4 successive hours, annual leave with pay, and overtime payment for work above 40 hours a week. The Indonesian government has also enacted a number of standards to improve conditions faced by women workers. Labor law no.12, 1948 has specific regulation for women workers. This law states : 
* Women workers will be entitled to paid leave of 1.5 months before giving birth or if they have a miscarriage.

* Women workers shall not be obliged to work on first and second day of menstrual period.

* Women workers have the chance to breast feed their babies.

Another act specifically for women is Act no. 1/1951 which states that women workers will not do night work except in cases in which the type, place and situation of the work are such that it is required to be done by women.

The problem raised with regard to the preferential statutory legislation for women is that this increases the associated costs of hiring women. Employers now have to provide a lot of benefits for women workers. As a result legislation aimed at protecting women, could result in depressing their wages or discouraging their employment (Agrawal, 1996). However, most cases show that employers often fail to meet the government-legislated standards.

One aspect of the above legislation, Article 10 Act no. 14/1969, states that the government shall promote labor protection including: safety standards, standards of health and hygiene, labor standards, and compensation for medical care and rehabilitation in the case of industrial injury. In 1981 government enacted legislation providing Lebaran bonus benefits and special leave. Further, in 1992 Jamsostek or Social Insurance Program was introduced for workers to provide life insurance, retirement benefits, free health care for workers, their spouses and up to three children and workers' compensation insurance for work related accidents and illness.

Although the Indonesian economy grew substantially after the deregulation process, international agencies including ILO have voiced concern that workers have not shared sufficiently in the benefits of growth. Moreover they criticized Indonesia for violations of labor standards. The government has reacted by increasing statutory rights and establishing minimum wage policy.

Although the centrally mandated benefits through legislation are generous, the welfare of the workers will not change unless means of enforcement of these benefits are revised. As indicated earlier, the difficulties in enforcing standards designed to protect workers are partly due to the lack of effective labor unions to represent workers. 


\section{III.4. Labor Union in Indonesia}

The objective to form unions is to mobilize power in which the union becomes an independent force to determine members' collective goals (Dufty, 1984). This objective can be achieved only if the workers are empowered or they are free to elect representatives (unions or other organizations) to bargain for higher wages and better working conditions with employers. Effective labor unions could play an important role in preventing labor abuses by helping to enforce existing labor legislation. In other words, voluntary negotiations between freely elected representatives and employers is an important factor in ensuring the application of the workers' statutory rights. In this case the role of government is essential in providing the framework for the representation of workers in collective bargaining.

The right of Indonesian workers to organize and to engage in collective bargaining is guaranteed in the 1945 Constitution article 28 . There are two laws that clearly guarantee the right to form a union. The first is law No.18 of 1956, which made ILO convention No 98, on the Right to Organize and Bargain collectively. Secondly, Basic Law No 14 of 1969, which states : 'the right to set up and become a member of a manpower union'. Nevertheless, it is difficult for unions to achieve a legally recognized status. In the New Order Era, only one labor organization has been able to meet the requirements for recognition as a union. That organization is the government-backed Indonesian Labor Federation which was originally a federation and became a unitary organization or Serikat Pekerja Seluruh Indonesia (All Indonesian Workers Union or SPSI). SPSI currently named to FSPI (Indonesian Labor Federation) is the only recognized union. At present there is no chance that the Government will recognize a new labor union outside the FSPI structure, since the most recent pronouncement of the Minister of Manpower affirmed that what is understood to be a workers' union is in fact the FSPI/SPSI. Since then the labor policy in Indonesia has focused on preserving stability and creating jobs while avoiding labor unrest (Cox Edwards, 1996). Dispute resolution which is regulated in 1957 indicates the big intervention of the government. According to Nusantara (1995:31) this situation reflects that workers' fundamental political rights, including the right to freedom of assembly and freedom of association, are denied. Indonesia has to pay attention to the issue of these democratic freedoms

particularly due to increased international pressure. Currently America is applying GSP as a sanction against perceived non democratic practices related to the labor industry in Indonesia. 
FSPI has been viewed as a government tool and as very weak in representing workers' aspirations. Consequently, workers do not have a say in the control of working conditions imposed upon them by their employers. The ineffectiveness of SPSI can be initially reflected by increasing labor unrest. Strikes can be attributed in part to the inability of workers to engage in productive negotiations with employers because of lack of confidence in union support for their cause. Second, the unionization rates in Indonesia are amongst the lowest in the world (Freeman, 1993). Of the 47,000 companies that employ 25 workers or more, only 40 percent of them have signed collective labor agreements with their workers (Cox-Edward, 1996).

An added problem hindering the effectiveness of unions is surplus labor. Strikes as a potent weapon for unions will not be effective if replacement workers can be easily found, even at a lower wage rate.

The government has recently brought out new regulations in an attempt to remove obstacles to having a voice and representation. Ministry of Manpower legalized a new form of representation at the level of the company (Serikat Pekerja Tingkat Perusahaan or SPTP). These can be formed within companies that do not have union representation and have a minimum of 25 employees. However, the fact that these new organizations do not have legal protection as union representatives and that the SPTP are required to unite with the Labor union of the corresponding business sector after 12 months, puts to question their independence and effectiveness to represent workers.

In considering future policy, voluntary agreements between freely elected representatives and employers is a basic requirement for establishing a modern and effective system of industrial relations. This means that legislation which is aimed at easing restrictions on unions and encouraging effective, democratic, plant level worker organizations by providing "voice" at the work place are needed. This will lead to an increase in worker productivity which is needed to preserve economic stability and growth.

\section{Descriptions of Survey}

The survey is focused on women working in the labor intensive textile, garment and the footwear industry. Women workers in this paper are defined as women who are working for other people or legal entities and are compensated in financial terms or payment in kind. The 
reason for choosing these industries is the abundance of women workers employed in these industries, as well as the similarity of the industries in terms of export orientation. In line with the characteristics of investment in Indonesia, these industries are characterized by low technology and labor intensity. The respondents of the study are women who work on the production line including those employed as supervisors. It does not include women working in administrative positions, personnel, treasury department, and other non manual work. It is assumed that the production division has the most cases of violations of the law and regulations.

\section{IV.1. Location}

The survey was administered in 5 locations: Jakarta, Bogor, Tangerang, Bekasi and Bandung. These areas are chosen for their concentration of textile, garment and footwear companies producing for export as well as for domestic use. The concentration in the location is in turn due to the adequate infrastructure and the close proximity to industrial activities.

\section{IV.2. Sample}

Since the focus of the study is on women workers in the export oriented, labor intensive and formal sector, the three sectors chosen were textile, garments and footwear which as indicated earlier (see Table 2) are export oriented and these sectors absorb nearly half of all women workers.

It was decided that the survey be conducted in Jakarta and West Java where these three industries are concentrated. The division of respondents was based on the relative number of women working in the three industries and located in Jakarta and West Java. Using such a basis the breakdown is: 19.67 per cent of women are in the textile industry, 51.42 per cent in garment, and 28.91 per cent in the footwear industry ${ }^{*}$. In number of respondents, 19.67 per cent $X 300=$ 60 respondents in the textile industry, 51.42 per cent $X 300=155$ in garment, and $28.91 \times 300=$ 85 in the footwear industry.

\footnotetext{
* If the division would be based on relative number of women workers in the three industries for all of Indonesia, the breakdown would have been (for medium and large scale companies only) : textiles $\mathbf{4 1 . 2}$ percent, garment 36 percent and footwear 23 percent.
} 
The respondents are then divided by the scale of company which is determined by the number of workers. Small scale company 5-19 workers, medium-scale 20-100 workers and large-scale company 100 or more workers. Based on scale the respondents are spread according to the percentage of companies in each output : 85 per cent in large-scale companies, 10 per cent in medium and 5 per cent in the small-scale companies. For the purpose of better analysis, small and medium scale companies have been grouped together. This was particularly necessary given the small sample size of the small scale enterprises.

The spread of respondents according to the type of industry and the scale, can be seen on Table 3. There are 50 respondents in large-sized textile companies, 5 in the medium, and 5 in the small-scale companies. In the garment industry, 130 in large, 15 in medium and 10 in small. In the footwear industry, 70 in the large-sized companies, 10 and 5 in the medium and small-sized respectively. The locations of companies are obtained from Central Bureau Statistics (BPS). A maximum of 5 respondents were interviewed from each company. The respondents usually live around their place of work. Once a respondent is found from a company and has been interviewed, she is asked to give a name and address of a friend from the same company who may in turn be the next respondent. This was the technique used in gathering 300 respondents.

This method has flaws since in practice there are respondents that need to be interviewed even though they are not from the specific randomly-chosen companies of each scale. As a result the respondents are not gathered by random sampling but more by "quota". Secondly, there might be some bias since friends are likely to work in the same section. Thirdly, by dividing the number of respondents according to the scale of the company, the number, especially for the small-scale industry is too small to be critically analyzed. However, allocating more respondents for the small-scale industry would not solve the problem, especially in the textile and footwear industries. This is because there are not many small-scale textile companies and there are hardly any women workers in the small-scale footwear companies (see Table 3).

Out of the 300 respondents, 84.6 percent are permanent and 15.4 percent have some other status. The analysis below is based on the 254 permanent workers interviewed for the survey. It is assumed that differences in wage rates and benefits are due to whether the worker is permanent or not, and the distinction in the 'terms of employment' from based on their status, can influence their awareness level of the work regulations. Therefore, narrowly focusing on the permanent workers (daily or monthly workers) eliminates 'noise' of the data. Furthermore, the identification of factors relevant to the variables can easily be identified. 
To ensure the absence of association between the variables analyzed, the 'Pearson chisquare probability' is used with 95 per cent accuracy.

TABLE 5

SAMPLE DESIGN

\begin{tabular}{|c|c|c|c|}
\hline BY OUTPUT & $\begin{array}{c}\text { TEXTILE } \\
\text { 32114, 32115, 32116, } \\
\text { 32121 }\end{array}$ & $\begin{array}{c}\text { GARMENT } \\
32210\end{array}$ & $\begin{array}{c}\text { FOOTWEAR } \\
32412,32411\end{array}$ \\
\hline $\begin{array}{c}\text { LARGE } \\
85 \%\end{array}$ & $\begin{array}{l}\% \text { of Workers } 19.67 \% \text {. } \\
\text { Sample: } 19.67 \% \mathrm{x} \\
0.85 \times 300 \text { respondents } \\
=50 \text { respondents } \\
\text { Required } 10 \text { firms }\end{array}$ & $\begin{array}{l}\% \text { of Workers } 51.42 \% \text {. } \\
\text { Sample: } 51.42 \% \mathrm{x} \\
0.85 \times 300 \text { respondents } \\
=130 \text { respondents } \\
\text { Required } 26 \text { firms }\end{array}$ & $\begin{array}{l}\% \text { of Workers } 28.91 \% \text {. } \\
\text { Sample: } 28.91 \% \times \\
0.85 \times 300 \text { respondents } \\
=70 \text { respondents } \\
\text { Required } 14 \text { firms }\end{array}$ \\
\hline $\begin{array}{c}\text { MEDIUM } \\
10 \%\end{array}$ & $\begin{array}{l}\% \text { of Workers } 19.67 \% \text {. } \\
\text { Sample: } 19.67 \% \mathrm{x} \\
0.1 \times 300 \text { respondents } \\
=5 \text { respondents } \\
\text { Required } 1 \text { firm }\end{array}$ & $\begin{array}{l}\% \text { of Workers } 51.42 \% \text {. } \\
\text { Sample: } 51.42 \% \mathrm{x} \\
0.1 \times 300 \text { respondents } \\
=15 \text { respondents } \\
\text { Required } 3 \text { firms }\end{array}$ & $\begin{array}{l}\% \text { of Workers } 28.91 \% \text {. } \\
\text { Sample: } 28.91 \% \mathrm{x} \\
0.1 \times 300 \text { respondents } \\
=10 \text { respondents } \\
\text { Required } 2 \text { firms }\end{array}$ \\
\hline $\begin{array}{c}\text { SMALL } \\
5 \%\end{array}$ & $\begin{array}{l}\% \text { of Workers } 19.67 \% \text {. } \\
\text { Sample: } 19.67 \% \text { x } \\
0.05 \times 300 \text { respondents } \\
=5 \text { respondents } \\
\text { Required } 1 \text { firm }\end{array}$ & $\begin{array}{l}\% \text { of Workers } 51.42 \% \text {. } \\
\text { Sample: } 51.42 \% \mathrm{x} \\
0.05 \times 300 \text { respondents } \\
=10 \text { respondents } \\
\text { Required } 2 \text { firms }\end{array}$ & $\begin{array}{l}\text { \% of Workers } 28.91 \% \text {. } \\
\text { Sample: } 28.91 \% \times \\
0.05 \times 300 \text { respondents } \\
=5 \text { respondents } \\
\text { Required } 1 \text { firm }\end{array}$ \\
\hline TOTAL & 12 & 31 & 17 \\
\hline
\end{tabular}

Source : BPS, Industrial Statistics 1993. For the first time workers in industrial sector distinguished according to gender.

Note:

1. Survey population: Women Workers in West Java and DKI Jakarta on Textile, Garment and Footwear Industries

2. Research area: Jakarta, Bogor, Tangerang, Bekasi, and Bandung

3. Total Respondents: 300

4. Maximum 5 Respondents are taken from each firm. 
TABLE 6

FIRMS SAMPLE BY AREA

\begin{tabular}{|c|c|c|c|}
\hline$\overline{\text { AREA }}$ & TEXTILE & GARMENT & FOOTWEAR \\
\hline JAKARTA & $\begin{array}{ll}\text { Large: } & 2 \\
\text { Medium: } & 0 \\
\text { Small: } & 0\end{array}$ & $\begin{array}{ll}\text { Large: } & 6 \\
\text { Medium: } & 0 \\
\text { Small: } & 0\end{array}$ & $\begin{array}{ll}\text { Large: } & 3 \\
\text { Medium: } & 0 \\
\text { Small: } & 0\end{array}$ \\
\hline BOGOR & $\begin{array}{ll}\text { Large: } & 2 \\
\text { Medium: } & 0 \\
\text { Small: } & 0\end{array}$ & $\begin{array}{ll}\text { Large: } & 5 \\
\text { Medium: } & 0 \\
\text { Small: } & 0\end{array}$ & $\begin{array}{ll}\text { Large: } & 4 \\
\text { Medium: } & 0 \\
\text { Small: } & 0\end{array}$ \\
\hline TANGERANG & $\begin{array}{ll}\text { Large: } & 2 \\
\text { Medium: } & 0 \\
\text { Small: } & 0\end{array}$ & $\begin{array}{ll}\text { Large: } & 5 \\
\text { Medium: } & 1 \\
\text { Small: } & 0\end{array}$ & $\begin{array}{ll}\text { Large: } & 3 \\
\text { Medium: } & 1 \\
\text { Small: } & 0\end{array}$ \\
\hline BEKASI & $\begin{array}{ll}\text { Large: } & 1 \\
\text { Medium: } & 0 \\
\text { Small: } & 0\end{array}$ & $\begin{array}{ll}\text { Large: } & 4 \\
\text { Medium: } & 1 \\
\text { Small: } & 0\end{array}$ & $\begin{array}{ll}\text { Large: } & 1 \\
\text { Medium: } & 0 \\
\text { Small: } & 0\end{array}$ \\
\hline BANDUNG & $\begin{array}{ll}\text { Large: } & 3 \\
\text { Medium: } & 1 \\
\text { Small: } & 1\end{array}$ & $\begin{array}{ll}\text { Large: } & 6 \\
\text { Medium: } & 1 \\
\text { Small: } & 2\end{array}$ & $\begin{array}{ll}\text { Large: } & 3 \\
\text { Medium: } & 1 \\
\text { Small: } & 1\end{array}$ \\
\hline TOTAL & 12 & 31 & 17 \\
\hline
\end{tabular}

\section{IV.3. Method of Data Gathering}

The data was gathered through interviews conducted with the respondents administered between October and December of 1995. The interviews were conducted at the respondent's home to better ensure honest responses and to provide a safer environment for the interviewers. The questionnaire used can be found in the Appendix. 


\section{Results of the Survey}

\section{V.1. Characteristics of the Respondent}

The 300 respondents interviewed from 13 companies in the textile, garment and footwear sectors are mostly young women, single, with junior high school education and come from villages.

TABLE 7

\section{CHARACTERISTICS OF RESPONDENTS}

$$
\mathbf{N}=\mathbf{3 0 0}
$$

\begin{tabular}{|c|c|c|c|c|c|c|c|}
\hline $\mathrm{AGE}$ & $\%$ & EDUCATION LEVEL & $\%$ & Living Arrangement & $\%$ & $\begin{array}{l}\text { EMPLOYNEWT } \\
\text { STATUS }\end{array}$ & 0 \\
\hline 15-19 Years & 27.0 & Primary School & 37.3 & Company's dormitory & 5.7 & Training & 3.7 \\
\hline 20-24 Years & 43.7 & Junior High & 32.4 & Parent's home & 20.0 & Permanent (daily) & 82.3 \\
\hline 25-29 Years & 16.3 & High School & 15.7 & With husband & 13.3 & Temporary & 0.3 \\
\hline $30-34$ Years & 5.7 & Vocational & 14.0 & Rental & 48.7 & Contract & 2.3 \\
\hline \multirow[t]{3}{*}{$>35$ Years } & 7.3 & $>$ High School & 0.7 & With family & 7.3 & Permanent (monthly) & 2.3 \\
\hline & & & & With employee & 2.3 & Pieces Based & 8.7 \\
\hline & & & & Others & 2.7 & Others & 0.3 \\
\hline $\begin{array}{l}\text { Place of } \\
\text { origin }\end{array}$ & $\%$ & $\begin{array}{l}\text { NUMBER OF YEARS } \\
\text { WORKMG WTHE } \\
\text { COMPANY }\end{array}$ & $\%$ & Marital status & $\%$ & $\begin{array}{l}\text { Total\% of } \\
\text { respondents } \\
\text { employed according } \\
\text { to industry type }\end{array}$ & $\%$ \\
\hline Provinces & 11 & $<1$ Year & 26.3 & Single & 70.7 & Textile & 20 \\
\hline District & 55 & 1.3 Years & 42.3 & Married & 25.7 & Garment & 51.7 \\
\hline From villages & 77.1 & 4-7 Years & 23.0 & Divorced/widowed & 3.7 & Footwear & 28.3 \\
\hline From cities & 22.9 & $>7$ Years & 8.3 & & & & \\
\hline
\end{tabular}

As can be seen from Table 7, the respondents comprise of 20 percent from textile, 52 percent from garment, and 28 percent from footwear companies. In terms of age breakdown, 70 percent of the women are below 24 years old, six percent are between the ages of $30-35$, and only seven percent are above 35 years old. Most of the women (71 percent) are single. Most companies do not have restrictions about hiring married women, however there is an informal restriction against pregnancy.

26 percent of the women are married, and four percent are widowed or divorced. The correlation between the ages and the marital status as indicated in Table 7 illustrate the great 
opportunity for women to enter the labor market at this phase of their lives. They are not burdened by family responsibilities and they are still in good physical health.

The majority of the respondents have only up to junior high school education, distributed as follows: 70 percent of the respondents are junior high school graduates, 30 percent are with vocational training and less than one percent of them have more than a high school education.

In terms of work experience, 69 percent of the women have less than 3 years working experience in the company; 23 percent have worked for $4-7$ years and eight percent of the respondents have worked for more than 7 years. Based on these statistics, one cannot conclude that the relatively short working period among young women signifies a high turn over of workers in the industry. The short working period more likely reflects their relatively young age, and thus the fact that they only started work recently. The short period of working in the company can also be attributed to changes in marital status among women. The nature of the work and the supply of labor also means that workers are easily replaced.

The type of work performed by the women workers is highly specialized, repetitive and does not require special skills. This type of work occurs in large scale companies with a large capacity to hire many workers. On the other hand, in a small-scale company, for example in the footwear industry, the work is mostly carried out by male employees undertaking more than one task in the production line. In this type of industry the company needs to hire less workers with a correspondingly reduced labor cost of production.

The status of workers is as follows: 82 percent of the respondents are daily workers, two percent are monthly workers and the rest are trainees, temporary workers, contracted, and on perpiece basis. The per-piece basis are usually found in the garment industry.

Almost half of the respondents (49 percent) live in rented rooms and the rest in the company's dormitory, their parent's home, with their husband, or other company accommodation. Workers in small companies often live in their own since the factories are usually in close proximity to their homes. Usually, the living conditions for female workers are better in their parent's or husband's home, than in a rented room. For independent women with only one source of income, the rental accommodation place they can afford is sub-standard. Living in their own home indicates marriage and normally a double income.

In general the rented accommodation is a barracks style dwelling divided into four or five rooms. Two or three residents rent one room at a cost ranging from $\mathrm{Rp}$. 10,000 up to $\mathrm{Rp}$ 60,000 (including electricity), per person per month. A small number of the dwellings have a 
bath room, however in most cases residents share public facilities. There is no kitchen and food is brought ready made from outside the accommodation. Drinking water is boiled in the bedroom. There is no furniture in the rooms, except for a plastic cupboard to store belongings and hang clothes. The plastic cupboard also serves to divide the "bedrooms" and to provide space where residents can receive friends and other guests. Workers sleep on a tiny mattress on the floor.

Respondents come from 11 provinces and 55 districts. The furthest province is Nusa Tenggara. The respondents' parents live mostly in the rural area ( $77 \%$ ) compared to only $23 \%$ in the urban area.

\section{V.2 Wages}

From the 300 respondents interviewed the data shows that they obtain a basic daily wage ranging from $\operatorname{Rp} 1,000$ to $R p 12,000$. On top of the daily wage, 20 percent of the respondents get a lunch and 40 percent get lunch allowance which amounts to $\operatorname{Rp} 100$ - Rp 3,300 per day. Furthermore 11 percent say they get transportation facilities and 19 percent get transportation allowance, with an allowance ranging between $\mathrm{Rp} 100$ to $\mathrm{Rp} 1,500$ per day. The total amount of income received are between $\mathrm{Rp} 2,800$ to $\mathrm{Rp} 12,820$ per day. There are respondents who are not aware of the breakdown of their wages and this implies the potential for the employer to misrepresent the compensation due to the worker.

For permanent workers (daily or monthly) 20 percent receive less than the Regional Minimum Wage (UMR), and 80 percent receive the required amount or more.

TABLE 8

\section{RECEIPT OF UMR IN RELATION TO COMPANY SIZE}

(\%)

\begin{tabular}{|c|c|c|c|c|}
\hline 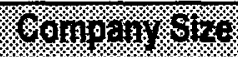 & Why & $\sqrt[3]{14}$ & W. & $2 \% 41411$ \\
\hline$<20-100$ & 57.14 & 8.57 & 25.71 & 8.57 \\
\hline$>100$ & 14.61 & 32.87 & 50.22 & 2.28 \\
\hline
\end{tabular}


Differences in the wage rate can be related to the size of the company, the type of product, and the period of work in the company. The level of education, age, or marital status do not influence the wage rate because of the menial nature of the job. 57 percent of the women working in the small and medium-scale companies receive less than UMR or Rp 4,600 per day (Table 8). Only 15 percent of the women in large-scale companies receive less than UMR. In fact, 53 percent of women working in the large companies receive more than UMR. If the allowances are considered, the rates will be much higher. The total take-home pay (basic pay + allowances) in the small and medium-scale companies is equal or more than UMR for 71 percent of the workers, or 14 percent more than for basic pay calculation. In the large-scale companies, for 85 percent of workers, their basic wage was greater than the UMR, and this rose to 95 percent, if allowances were included. Overall, this demonstrates that company compliance on UMR as expected depends on capability of the company to pay. Respondents working for large companies are more likely to receive wages in line with UMR compared to respondents from small/medium companies. The large companies, especially multinational corporations, tend to comply with government regulations on minimum wages as they tend to be more securitized.

\section{TABLE 9}

\section{UMR IN RELATION TO TYPE OF INDUSTRY}

\section{(\%)}

\begin{tabular}{|c|c|c|c|c|c|c|c|c|c|}
\hline 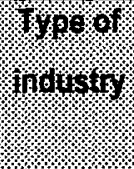 & 8 & 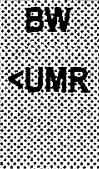 & . & $=40$ & $\frac{10}{61019}$ & 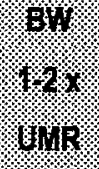 & $\sqrt{10}$ & \% & $\sqrt{4}$ \\
\hline Textile & 51 & 9.8 & 5.88 & 33.3 & 1.96 & 52.94 & 84.31 & 3.92 & 7.84 \\
\hline Garment & 127 & 14.96 & 3.93 & 32.28 & 8.66 & 48.03 & 81.10 & 4.72 & 6.29 \\
\hline Footwear & 76 & 36.84 & 25.0 & 22.36 & 3.94 & 40.78 & 71.05 & - & - \\
\hline
\end{tabular}

\section{Note :}

$\mathrm{BW}=$ Basic Wage

Total = Basic Wage + Meal Allowance + Transport Allowance + Other Allowance 
TABLE 10

\section{UMR IN RELATION TO INDUSTRY TYPE AND COMPANY SCALE CATEGORIES}

(\%)

\begin{tabular}{|c|c|c|c|c|c|c|c|c|c|}
\hline & \multicolumn{3}{|c|}{ Ff } & \multicolumn{3}{|c|}{$61 n n=1 \%$} & \multicolumn{3}{|c|}{$1304 \%$} \\
\hline & \% & $401 \%$ & 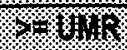 & $\sqrt{1}$ & 40 & (4) & \% & WIIK & 1 अ \\
\hline$<20-100$ & 5 & 60.0 & 40.0 & 15 & 26.7 & 73.3 & 15 & 86.7 & 13.3 \\
\hline$>100$ & 46 & 4.3 & 95.7 & 112 & 13.4 & 86.6 & 61 & 24.6 & 75.4 \\
\hline
\end{tabular}

Tables 9 and 10 illustrate that a higher percentage of workers, 37 percent, in the footwear industry (small, medium or large scale) do not receive wages equal to UMR. The percentage receiving less than UMR is only 10 percent in textiles and 15 percent in garments. Furthermore, more than 50 percent of workers in the textile industry receive one or two times the UMR (which is the highest portion of the workers). In the garment industry, 48 percent receive 1-2 times more than UMR and in the footwear industry this falls to 40 percent.

Even in the large-scale industry, the percentage of workers receiving less than UMR is largest in the footwear industry. As can be seen from Table 10, four percent of the workers in the large-scale textile companies receive below UMR, 13 percent in the garment industry, and 25 percent in the footwear industry.

The analysis indicates that years spent in a company is a factor in determining the amount of wages. Table 11 shows the relationship between length of employment and wage rates. The longer the period of work, the lower the percentage of workers getting below UMR and the higher the percentage of workers getting twice the UMR. Among the respondents who have worked in the same company for more than 7 years, 13 percent receive less than UMR, which is a higher percentage compared with 11 percent receiving less than UMR for those who have worked for 4-7 years. It is possible that some of the older workers are less educated than the younger ones and are less aware of their legal rights. 
TABLE 11

\section{UMR IN RELATION TO LENGTH OF EMPLOYMENT}

(\%)

\begin{tabular}{|c|c|c|c|c|c|c|c|c|c|}
\hline & \% & 4 & 8 & 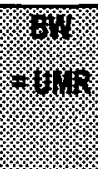 & 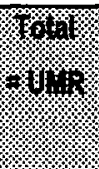 & $\frac{1}{4}$ & $\frac{1}{4}$ & $\sqrt[4]{1 / 2}$ & 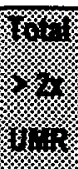 \\
\hline$<1$ year & 62 & 30.6 & 25.8 & 33.9 & 9.7 & 35.5 & 64.5 & - & - \\
\hline $1-3$ year & 113 & 21.2 & 8.0 & 38.1 & 7.1 & 38.9 & 81.4 & 1.8 & 3.5 \\
\hline $4-7$ year & 55 & 10.9 & 1.8 & 7.3 & 1.8 & 78.2 & 89.1 & 3.6 & 7.3 \\
\hline$>7$ year & 24 & 12.8 & 4.2 & 29.2 & - & 41.7 & 79.2 & 16.7 & 16.7 \\
\hline
\end{tabular}

Note :

$\mathrm{BW}=$ Basic Wage

Total = Basic Wage + Meal Allowance + Transport Allowance + Other Allowance 


\section{BOX I : THE EXPENSES OF WOMEN WORKERS}

On average, women workers earn Rp 115,000 - Rp 150,000 (U\$ 50 - U\$ 70) per month based on earning $R p 4,600$ as a daily wage, plus overtime payments and other bonuses. Most of the respondents said that they did not receive any financial support from their parents. They stated they would be embarrassed to ask for financial assistance since being employed is equated with being independent. Because of this, earning such a small income means being very thrifty in an attempt to pay necessary expenses without any further financial assistance.

In order to save money workers share accommodation in a rented room with one or two friends. Sharing costs can assist workers to save, each person in a shared situation usually pays $R p$ 15,000 , including electricity, per month. They spend around $R p 30,000-\operatorname{Rp~} 40,000$ per month for meals. Other basic living expenses are spent on buying sugar, dried tea, soap, shampoo, powder and mosquito repellent coils. Another substantial expense is sending money to their parents. The amount of money workers send home varies from around $\mathrm{Rp} 2,000$ - Rp 50,000 per month. Respondents stated that sending money to their parents is a kind of obligation and a token of appreciation or respect. One young women looked very embarrassed when she said that she was not able to send any money home because her income was not sufficient to cover all of her basic living expenses. She also admitted that she is less shrewd with her finances, a practice which is viewed negatively by others.

In the event of sickness if it is not serious, the women cure themselves by buying medicine from the stall. Extra expenses occur when engaging in social activities such as buying gift or visiting relatives. Nevertheless, most of the workers save some money. The most popular saving method among the women workers is "arisan" or the rotating lottery. These savings will be spent on the 'lebaran' celebration, when workers travel to their original hometown or village.

The need for workers to increase their income can be seen from their enthusiasm in taking on overtime work. Although the overtime payment is very low, with long hours of overtime it increased their income substantiaily. Another sign of the need for workers to receive their full pay is their low absenteeism rate. Workers will lose their wage if they are absent from work. Generally it can be seen that workers depend on receiving their small wage in order to enable them to acquire their basic necessities.

\section{V.3 Compliance With Labor Regulations}

This section presents the answers given by the respondents on wage matters, benefits and their rights. Workplace benefits received are then compared with the regulations. From the comparison, the percentages of compliance with each of the regulations can be shown, and the types of benefits complied with least can also be identified.

From the response as indicated in Table 12, maternity leave has the highest compliance with 96 percent of the permanent worker respondents responding to having received maternity leave, which is $1 \frac{1}{2}$ months before and after the birth. A large majority of the respondents (91 
percent) also indicated that the companies comply to the work hour regulation which is 40 hours per week ( 42 hours to be exact since the workers work on average 7 hours 6 days a week).

The majority of the companies also comply by providing maternity pay benefits, with 89 percent of them giving 3 months pay during the leave. On the other hand there is a low level of compliance in providing breast-feeding facilities, menstrual leave, menstrual benefits and overtime pay rates.

To comply with the breast-feeding facilities regulations, companies must provide daycare to house the children so that the mothers do not have to go home to feed babies. Some of the companies allow mothers two hours off to breastfeed their baby in their own home. This is difficult in practice, since the distance between the work place and home is often far and will often take longer than 2 hours.

Only 30 percent of the respondents receive over time rates according to the government regulation ( 31 percent for the first hour rate, and 26 percent for the subsequent hour rate). This is somewhat of concern, since 77 percent of the 300 respondents say that they work overtime and 31 percent of them work more than 12 hours overtime a week. Workers will take any opportunity to work overtime even if the pay is small. Since the additional pay will still add substantially to their earnings.

In the case of menstrual leave, the companies usually "buy the leave" by paying the women 2 days extra wages per month to encourage women workers to work on the 2 days of identified menstrual leave. However, if the workers are absent because of menstrual reasons, they don't get any pay at all. There are also some cases where the leave is given to men for reasons of "equality"!

In the case of Indonesia two main reasons can be postulated for non-compliance. First, firms that are unable to financially offer the legislated benefits or minimum wage, this situation is usually faced by the small companies. The second is the lack of enforcement capabilities. The government does not implement effective sanctions for those who do not comply. As a result there is always an incentive for a firm to ignore the rules. Economic sanctions must have a noticeable effect on the company, for example in terms of minimum wages, transgressors of minimum wage laws incur a fine of approximately $\$ U S 50.00$ which is a low sum for large companies.

The company's compliance depends on the scale of the company. A worker from a large-scale company is more likely to receive benefits according to the regulations than a worker 
from the smaller-scale companies, (Table 13 and Figure 1 in Appendix). There are insignificant differences in the breast-feeding facilities provided by the large-scale and the small and mediumscale companies. Generally however, they do not provide adequate facilities.

TABLE 12

RESPONDENTS EXPERIENCE OF COMPANY COMPLIANCE WITH WORKPLACE BENEFITS

$(\%)$

\begin{tabular}{|c|c|c|c|c|}
\hline & \multirow[t]{2}{*}{ \% } & \multirow[t]{2}{*}{ 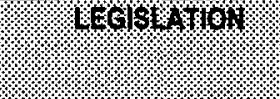 } & \multicolumn{2}{|c|}{$0.7 \%$} \\
\hline & & & ShEG & 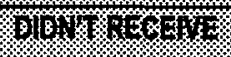 \\
\hline $\begin{array}{l}\text { Maternity leave ent. } \\
\text { (days) }\end{array}$ & 27 & 1.5 months befor\&after & 96.3 & 0.7 \\
\hline Working hours & 254 & $\max .40 \mathrm{hr} /$ week & 90.9 & 9.1 \\
\hline $\begin{array}{l}\text { Maternity leave ent. } \\
\text { (wages) }\end{array}$ & 27 & 3 months wage & 88.9 & 11.1 \\
\hline Wage per day & 254 & Rp 4600 per day & 79.5 & 20.5 \\
\hline Annual leave ent. (days) & 254 & 12 days/year & 73.2 & 26.8 \\
\hline $\begin{array}{l}\text { Annual leave ent. } \\
\text { (wages) }\end{array}$ & 254 & 12 days wages & 70.5 & 29.5 \\
\hline Overtime & 196 & $\max .12$ days & 60.2 & 39.8 \\
\hline Lebaran Bonus (Rp) & 214 & 1 month wage & 44.4 & 55.6 \\
\hline $\begin{array}{l}\text { Menstrual leave ent. } \\
\text { (wages) }\end{array}$ & 254 & 2 days wages & 37.8 & 62.2 \\
\hline $\begin{array}{l}\text { Menstrual leave ent. } \\
\text { (days) }\end{array}$ & 254 & 2 days/month & 37.4 & 62.6 \\
\hline Wages \&benefits for & & & & \\
\hline OT: Meal & 160 & meal & 63.0 & 37.0 \\
\hline Transportation & 158 & transportation & 62.2 & 37.8 \\
\hline First hour & 145 & $1.5 \times$ hourly wage & 31.0 & 69.0 \\
\hline Subsequent hours & 123 & $2 x$ hourly wage & 26.0 & 74.0 \\
\hline Breastfeeding facilities & 254 & 2 hours breastfeeding & 6.3 & 93.7 \\
\hline
\end{tabular}


TABLE 13

\section{RECEIPT OF ENTITLEMENTS IN RELATION TO COMPANY SIZE}

(\%)

\begin{tabular}{|c|c|c|c|c|c|c|}
\hline & 11. & 4. & $4 \%$ & \%. & \% & . \\
\hline Menstrual leave ent. (days) & 35 & 2.9 & 97.1 & 219 & 42.9 & 57.1 \\
\hline Maternity leave ent. (wages) & 35 & 5.7 & 94.3 & 219 & 42.9 & 57.1 \\
\hline Annual leave ent. (wages) & 16 & 28.6 & 71.4 & 219 & 77.2 & 22.8 \\
\hline Lebaran bonus & 28 & 17.9 & 82.1 & 186 & 48.4 & 51.6 \\
\hline OT first hour & 16 & - & 100 & 129 & 34.9 & 65.1 \\
\hline OT subsequent hour & 14 & - & 100 & 109 & 29.3 & 70.7 \\
\hline
\end{tabular}

ent $=$ entitlements.

The types of industry and length of employment also determines the level of company compliance to workers' benefit and labor regulations. The responses are illustrated in Table 14. The footwear industry has the lowest level of compliance, including with regard to maternity benefits, holiday pay, and overtime pay. 
TABLE 14

\section{RECEIPT OF ENTITLEMENTS IN RELATION TO INDUSTRY TYPE}

(\%)

\begin{tabular}{|c|c|c|c|c|c|c|c|c|c|}
\hline 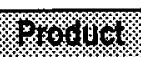 & \multicolumn{3}{|c|}{ 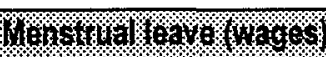 } & \multicolumn{3}{|c|}{ 6) 6rata } & \multicolumn{3}{|c|}{ 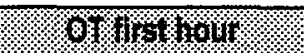 } \\
\hline & 10. & \%rs & 180 & \% & Wer & 110 & W & \%w. & \% \\
\hline Textile & 51 & 52.9 & 41.1 & 46 & 53.4 & 46.6 & 20 & 40.0 & 60.0 \\
\hline Garment & 127 & 37.8 & 62.2 & 109 & 44.0 & 56.0 & 75 & 32.0 & 68.0 \\
\hline Footwear & 76 & 27.6 & 72.4 & 59 & 37.3 & 62.6 & 50 & 26.0 & 74.0 \\
\hline
\end{tabular}

Table 15 provides the breakdown with regard to compliance by the length of employment. It shows that, on average, workers who have been with a company longer tend to receive more of the benefits. In addition it should be noted that the respondents who work in the larger companies are more likely to enjoy other benefits, for example, health insurance, prenatal care, as well as family planning facilities.

TABLE 15

\section{RECEIPT OF ENTITLEMENTS IN RELATION TO LENGTH OF EMPLOYMENT}

(\%)

\begin{tabular}{|c|c|c|c|c|c|c|c|c|c|}
\hline \multirow[t]{2}{*}{ 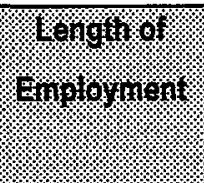 } & \multirow[t]{2}{*}{ \% } & \multicolumn{2}{|c|}{ 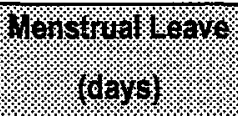 } & \multicolumn{2}{|c|}{ 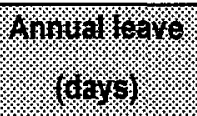 } & \multicolumn{2}{|c|}{ / } & \multicolumn{2}{|c|}{ Honsurvar. } \\
\hline & & W/ & 16 & Wrs. & 11. & W/ & 110 & W6. & $1 \%$ \\
\hline$<1$ year & 62 & 17.7 & 82.3 & 59.7 & 40.3 & 45.4 & 54.6 & 16.1 & 83.9 \\
\hline $1-3$ years & 113 & $\overline{34.5}$ & 65.5 & 67.3 & 32.7 & 27.4 & 72.6 & 41.6 & 58.4 \\
\hline $4-7$ years & 55 & 58.2 & 41.7 & 74.6 & 25.4 & 54.6 & 45.4 & 49.1 & 50.9 \\
\hline$>7$ years & 24 & 54.2 & 45.8 & 83.3 & 16.6 & 62.5 & 37.5 & 50 & 50 \\
\hline
\end{tabular}




\section{BOX 2. MENSTRUAL LEAVES : A HUNDRED WAYS TO GET AROUND IT}

Up until now the reasons for unsatisfactory compliance to certain benefits such as menstrual leave have not been clear. Is it because the company is unable to provide the benefits ? Is it because of the lack of government control? Or is it because benefits are generally viewed as unnecessary, especially in relation to the special treatment of women workers. What is clear is that companies are unwilling to provide these benefits either by not providing them at all, or by trying to get around the requirement. In the case of menstrual leave, the regulation states that female employees shall not be obliged to work on first and second day of the menstrual period. There are several practices that have been taken by companies in order to evade any incurred costs or reduced productivity because of the menstrual leave requirement.

As mentioned in this report, the companies usually 'buy the leave' by paying the women two days extra wages per month to encourage them to work on the two days of identified menstrual leave. However, if the workers are absent because of menstrual reasons, they don't get any pay at all. One respondent mentioned that in her company the workers are only allowed to take menstrual leave every two months. This means the company only provides for half of the overall cost that they should pay. Another case shows menstrual leave is given to both men and women workers. According to the respondents the reason behind this practice is that menstruation is viewed as a sickness, therefore the male workers also deserve to get leave.

There are some companies that asked women workers to show a letter from the doctor in order to get menstrual leave with pay. This survey also found that in a certain company, the guard checked the women workers to prove whether they were menstruating or not. The company's effort to get around providing legislated menstrual leave also can be seen where, if workers took two days menstrual leave, they are paid only for the first day and on the second day they did not get paid at all. In other cases respondents said that the company only paid $75 \%$ of the daily wage if the workers took menstrual leave. The last case was that menstrual leave is given on a rotating basis among workers.

The above cases indicate that companies do not believe that women workers should get special treatment when they menstruate. This can be seen from the fact that companies try very hard to avoid paying the full costs associated with menstrual leave. Compared to other countries such as Malaysia, Mexico, Australia, United States and Chile, who do not provide menstrual leaves, Indonesia is very generous. Another country that provides menstrual leave is Korea. It gives one day leave with pay for menstruation every month.

The question arises as to whether menstrual leave burdens companies so much so that the regulation on menstrual leave should be changed, and a more suitable regulation found. Or is this a morale issue, where companies are not complying merely because they do not believe that women workers should receive special entitlements? There is a need to clearly establish why menstrual leave entitlements are not being met by companies and, if the entitlement remains, we need to find a better mechanism to enforce company compliance with the legislation. 
TABLE 16

PROVISION OF FACILITIES IN RELATION TO COMPANY SIZE CATEGORY

(\%)

\begin{tabular}{|c|c|c|c|c|c|c|c|c|c|}
\hline \multirow[t]{2}{*}{ GoMf. } & \multirow[b]{2}{*}{19} & \multicolumn{2}{|c|}{ 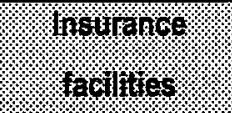 } & \multicolumn{2}{|c|}{ 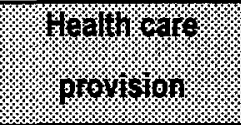 } & \multicolumn{2}{|c|}{ 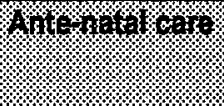 } & \multicolumn{2}{|c|}{ 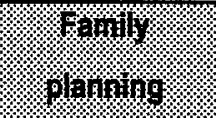 } \\
\hline & & Wro & 18 & (6) & 10\% & $\%$ & 68 & Y8. & $6 \%$ \\
\hline$<20-100$ & 35 & 25.71 & 74.29 & 28.57 & 71.43 & 2.85 & 97.15 & 0.28 & 99.72 \\
\hline$>100$ & 219 & 77.16 & 22.84 & 77.62 & 22.38 & 37.44 & 62.56 & 31.5 & 68.5 \\
\hline
\end{tabular}

In 1992, the Indonesian government issued a health, life and pension insurance regulation (Jaminan Sosial-JAMSOSTEK) which is intended to compensate for loss of wages due to work-related accidents, illness, pregnancy, giving birth, pension, and death. Jamsostek is intended to care and improve the well being of the workers. Out of the permanent workers, 62 percent of the respondents say that they participate in such a program, 31 percent do not participate and seven percent do not know about it. However, whether or not they will eventually enjoy the benefits needs further study.

\section{V.4. Health and Safety Provision}

Alongside the wages and benefits issue, this survey incorporated a study on the provision and the implementation of health and safety precautions. The study includes the facilities and the provision of occupational health and safety equipment, and the availability of clean drinking water, first aid, toilets, heath clinic, doctor, nurse, and instructions on how to use equipment and materials safely. Fire drills and the availability of protective equipment (gloves, masks, footwear, hair covering) are included in the study.

Table 17 provides the responses regarding the provision of fresh drinking water $(97$ percent provided), first aid ( 91 per cent), toilets ( 82 percent) and training on how to use the safety equipment ( 76 percent). In contrast to these statistics, only 17 percent have received fire drills. 
From the 254 permanent workers surveyed, 64 percent say they are provided with protective equipment, 80 percent of them have received a mask, six percent have received goggles, 36 percent have received gloves and 24 percent have received footwear. The frequency of use of the equipment is shown in Table 18 with 90 per cent of the respondents wearing their goggles, 72 per cent wearing their footwear (most wear their own), 46 per cent wearing their mask, and 66 percent wearing hair covering.

\section{TABLE 17}

\section{ACCESS TO HEALTH AND SAFETY PROVISIONS}

(\%)

\begin{tabular}{|c|c|c|}
\hline & (6) & 10 \\
\hline Drinking water & 96.5 & 3.5 \\
\hline First aid & 91.3 & 8.7 \\
\hline Toilet & 81.9 & 10.1 \\
\hline Training & 76.4 & 23.6 \\
\hline Clinic & 55.1 & 44.9 \\
\hline Doctor & 53.9 & 46.1 \\
\hline Nurse & 48 & 52 \\
\hline Fire safety & 16.9 & 83.1 \\
\hline Safety Equipment & 63.8 & 36.2 \\
\hline Mask & 80.2 & 19.8 \\
\hline Hair coverings & 43.8 & 56.2 \\
\hline Gloves & 35.8 & 64.2 \\
\hline Others & 31.5 & 68.5 \\
\hline Footwear & 24.1 & 75.9 \\
\hline Hearing protection & 11.1 & 88.9 \\
\hline Goggles & 6.2 & 93.7 \\
\hline
\end{tabular}


TABLE 18

USE OF PROVIDED SAFETY EQUIPMENT

(\%)

\begin{tabular}{|c|c|c|c|c|}
\hline EOUPMENH & $1 \%$ & 18 & Mo. & 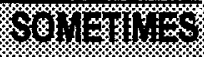 \\
\hline Goggles & 10 & 90.0 & 10.0 & - \\
\hline Footwear & 39 & 71.8 & 20.5 & 7.7 \\
\hline Hair covering & 71 & 66.2 & 23.9 & 9.9 \\
\hline Gloves & 58 & 48.3 & 31.0 & 20.7 \\
\hline Mask & 130 & 46.2 & 18.5 & 35.4 \\
\hline Hearing protection & 18 & 22.2 & 72.2 & 5.6 \\
\hline
\end{tabular}

Reasons for not using their protective equipment are as follows: 36 percent say that they are not comfortable, 17 percent say they do not like them and nine percent say they are not effective (Table 19).

TABLE 19

REASON FOR NOT USING SAFETY EQUIPMENT $(\%)$

\begin{tabular}{|c|c|}
\hline WOOH & orowory \\
\hline Uncomfortable & 36.4 \\
\hline Prefer not using & 16.9 \\
\hline Not effective & 8.6 \\
\hline
\end{tabular}

$$
N=162
$$

From the response to the questionnaire, the provision of safety equipment is dependent upon the scale of the establishment. The large-scale companies are more likely to provide health and safety equipment and facilities compared to the small and medium-sized companies (Table 
20 ), with 62 percent of the respondents from large-scale companies indicating that there is a polyclinic at the premises compared to only 11 percent from the small and medium-scale companies. Furthermore, 71 percent of the respondents from large-scale companies receive protective gear compared to only 20 percent from the smaller companies. However, there is no identifiable difference in the frequency of conducting fire drills: both respondents from largescale and the small-medium sized companies, stated that fire drills were very rare.

The difference suggests a mere correlation between scale and provision. Clearly, it might not be cost effective for a small company, which has a maximum of 100 workers, to provide a polyclinic or have a doctor or nurse on staff. It might be more efficient to send a sick worker to a health facility outside the company.

\section{TABLE 20}

\section{ACCESS TO SAFETY EQUIPMENT IN RELATION TO COMPANY SIZE}

\section{(\%)}

\begin{tabular}{|c|c|c|c|c|}
\hline & \multicolumn{2}{|c|}{$(20100 \%$} & \multicolumn{2}{|c|}{86160} \\
\hline & \multicolumn{2}{|c|}{$15 \% 6$} & \multicolumn{2}{|c|}{ 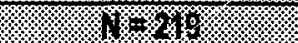 } \\
\hline & 16 & $1 \%$ & TES & $\%$ \\
\hline toilet & 65.7 & 34.3 & 84.5 & 15.5 \\
\hline first aid & 65.7 & 34.3 & 95.4 & 4.6 \\
\hline training equipment & 54.3 & 45.7 & 79.9 & 20.1 \\
\hline health and safety eq. & 20 & 80 & 70.8 & 29.2 \\
\hline clinic & 11.1 & 88.6 & 62.1 & 37.9 \\
\hline nurse & 2.9 & 97.1 & 55.3 & 44.7 \\
\hline doctor & 14.3 & 85.7 & 60.3 & 39.7 \\
\hline
\end{tabular}

More than 80 percent of the respondents state that they are experiencing a health related problem and 60 percent of them say the problem is caused by the work environment. The work related illnesses are presented in Table 21. 
TABLE 21

\section{HEALTH PROBLEMS EXPERIENCED BY RESPONDENT}

(\%)

\begin{tabular}{|c|c|c|}
\hline 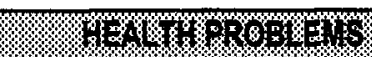 & 4 & YROL1) \\
\hline Frequent headaches & 211 & 50.2 \\
\hline Tired & 211 & 45.0 \\
\hline Back pain & 211 & 44.1 \\
\hline Skin condition & 211 & 17.1 \\
\hline Respiratory problems & 211 & 17.1 \\
\hline Others & 69 & $27 \ldots ?$ \\
\hline
\end{tabular}

The most frequent complaints are headaches, backaches, and fatigue, with half of the permanent workers suffering from a chronic headache, 45 percent suffering from fatigue, and 44 percent from a backache. However, absenteeism is very low. A third of the respondents have never been absent from work and 40 percent have been absent for less than five days during the whole year.

From the respondents who reported an illness, 38 per cent go the company's clinic and usually receive free medication, 13 per cent go to a Puskesmas, 30 per cent go to a private doctor and the rest go to a public or private hospital.

\section{V.5. Knowledge of Standard Working Conditions, Wages and Benefits}

Collectively, the awareness of workers with regard to the rules and regulations is low. As seen in Table 22, most workers are aware about the minimum pay regulation and even then only 41 percent of the respondents responded that they knew that the UMR (regional minimum wage) is $R p 4,600$. With regard to the other regulations, only 37 per cent are aware of the length of maternity leave, only 35 per cent know that the legal annual leave is 12 days, and only two percent know the over-time wage rates. In general, the workers are indifferent towards the wage rates alone, and care only about the overall financial compensation received each week. Only 12 percent are aware of the law regulating companies to provide facilities for mothers to breast-feed 
their babies. In addition, only 26 percent of the respondents know that the "Lebaran bonus" is one month's salary.

TABLE 22

\section{KNOWLEDGE OF STANDARD WORKING CONDITIONS, WAGES, AND BENEFITS}

\begin{tabular}{|c|c|c|c|}
\hline 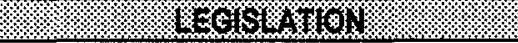 & 0 & mox & 600121409 \\
\hline UMR entitlements & 254 & 40.6 & 59.4 \\
\hline Maternity leave entitlements (days) & 27 & 37.0 & 63.0 \\
\hline Annual leave entitlements (days) & 254 & 35.0 & 65.0 \\
\hline Menstrual leave entitlements (days) & 254 & 31.9 & 68.1 \\
\hline Maternity leave ent. (wages) & 254 & 30.3 & 69.7 \\
\hline Lebaran Bonus & 254 & 26.0 & 74.0 \\
\hline Annual leave entitlements (wages) & 254 & 26.8 & 73.2 \\
\hline Menstrual leave entitlements (wages) & 254 & 26.8 & 73.2 \\
\hline Breastfeeding entitlements and facilities & 254 & 11.8 & 88.2 \\
\hline $\begin{array}{l}\text { Wages and benefits for OT: } \\
\text { First hour; } \\
\text { Subsequent hour; } \\
\text { meal \& transportation }\end{array}$ & 254 & $\begin{array}{l}2.4 \\
2.8 \\
2.0\end{array}$ & $\begin{array}{l}97.6 \\
97.2 \\
98.0\end{array}$ \\
\hline
\end{tabular}

A comparison of workers' awareness and the level of compliance to labor regulations by companies shows that those regulations that the workers know least about (over-time pay and breast-feeding facilities) are also those with which there is low compliance by companies. On the other hand, benefits with a high compliance level are also those which are known to larger numbers of respondents. These observations indicate that these is a positive relationship between knowledge and compliance with regard to wage and benefits related issues. Keeping in mind that wage regulations are amongst the most well-known regulations, the most common conflict is also wage related. It should also be made clear, however, that lack of knowledge of the regulations cannot be used as a single determinant to be linked with compliance by companies.

Tables 23 and 24 further clarify the relationship. Table 23 points to the relationship between the level of knowledge of benefits and regulations and the size of the companies, and Table 24 points to the relationship between the level of awareness and the type of industries. The respondents from the footwear industry have a lower level of awareness compared to the garment 
and textile industries. At the same time, the level of compliance by the footwear company is also the lowest among the industries surveyed.

TABLE 23

\section{KNOWLEDGE OF ENTITLEMENTS IN RELATION TO COMPANY SIZE CATEGORY}

(\%)

\begin{tabular}{|c|c|c|c|c|c|c|c|c|c|c|c|}
\hline \multirow{2}{*}{ 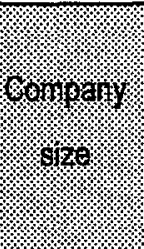 } & \multirow[t]{2}{*}{1} & \multicolumn{2}{|c|}{ U. } & \multicolumn{2}{|c|}{ Mensturaterater } & \multicolumn{2}{|c|}{ (1) } & \multicolumn{2}{|c|}{ (114) } & \multicolumn{2}{|c|}{ 46.4. } \\
\hline & & $\sqrt{610 \%}$ & 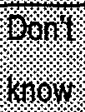 & Krovy & Born?: & (Knour? & $\sqrt{6} 6.6 \%$ & \% & 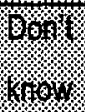 & \%on & \% \\
\hline$<20-100$ & 35 & 20 & 80 & 11.4 & 88.6 & 5.7 & 94.3 & - & 100 & 5.7 & 94.3 \\
\hline$>100$ & 219 & 43.8 & 56.2 & 35.2 & 64.8 & 30.1 & 69.9 & 31.1 & 68.9 & 29.2 & 70.8 \\
\hline
\end{tabular}

Despite the low awareness level, the percentage of respondents who receive benefits are in fact quite high. For example, the percentage of respondents who are aware about the level of the UMR is 41 percent while the percentage of the respondents who receive at least the UMR is 80 percent. Similarly with maternity leave and yearly holiday entitlements: only 30 percent are aware of maternity leave entitlements; while 90 percent of those eligible receive it; and while only 27 percent of respondents are aware of the length of the yearly holiday, 71 percent receive it. The high level of compliance could be attributed to the strict inspection from government officials, keeping in mind that most of the respondents work in the highly concentrated industrial zone where lack of compliance by companies will be quickly noticed with adverse consequences.

Although compliance is observed by companies inspite of low levels of awareness, it is still important that workers know the rules and regulations that protect them. Firstly, women workers have to know their rights to ensure fair treatment. Secondly, even if the worker is getting the minimum wage, and the company is complying, the worker might still feel dissatisfied. Conflict might arise due to worker dissatisfaction. If the workers are knowledgeable about the rules and regulations, violations can be reported to SPSI (now FSPI United Federation of Indonesian Workers). 
TABLE 24

KNOWLEDGE OF ENTITLEMENTS IN RELATION TO INDUSTRY TYPE

(\%)

\begin{tabular}{|c|c|c|c|c|c|c|c|c|c|c|c|}
\hline \multirow[t]{2}{*}{$10 \%$} & \multirow[b]{2}{*}{$11 \%$} & \multicolumn{2}{|c|}{ U19? } & \multicolumn{2}{|c|}{ 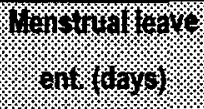 } & \multicolumn{2}{|c|}{ Wenthor } & \multicolumn{2}{|c|}{ (1910) } & \multicolumn{2}{|c|}{ 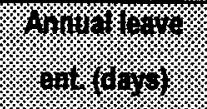 } \\
\hline & & (rino & 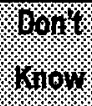 & Srrov & rong & Know & 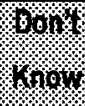 & (Tirom & 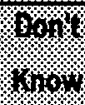 & 6ro & 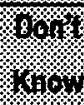 \\
\hline Textile & 51 & 41.2 & 58.8 & 41.2 & 58.8 & 39.2 & 60.8 & 52.9 & $\overline{477.1}$ & 33.3 & 66.7 \\
\hline Garment & 127 & 47.2 & 52.8 & 33.9 & 66.1 & 27.6 & 72.4 & 37.0 & 63.0 & 30.7 & 69.3 \\
\hline Footwear & 76 & 28.9 & 71.1 & 22.4 & 77.6 & 17.1 & 82.9 & 19.7 & 80.3 & 15.8 & 84.2 \\
\hline
\end{tabular}

\begin{tabular}{|c|c|c|c|c|c|c|c|}
\hline \multirow[t]{2}{*}{00010} & \multirow[b]{2}{*}{6} & \multicolumn{2}{|c|}{ 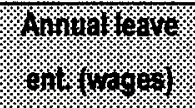 } & \multicolumn{2}{|c|}{ 16\% } & \multicolumn{2}{|c|}{ \%oinsountir } \\
\hline & & (1) & (16, & Wom & . & Ko\% & \% \\
\hline Textile & 60 & 28.3 & 71.7 & 5.0 & 95.0 & 5.0 & 995.0 \\
\hline Garment & 155 & 28.4 & 71.6 & 1.9 & 98.1 & 1.9 & 98.1 \\
\hline Footwear & 85 & 16.5 & 83.5 & 1.2 & 98.8 & 1.2 & 98.8 \\
\hline
\end{tabular}

Note: UMR = Minimum Regional Wage

The level of awareness is further determined by other characteristics such as where workers are from, their age, level of education and work experience. Respondents from Java have a higher level of awareness of the rules and regulations compared to respondents from other places (Table 25). An explanation for this difference is that most of the respondents are from Java and that there is the spread of information through communication between workers. From the 300 respondents interviewed, 43 percent are from Central Java and East Java. People from the same area usually live in the same proximity, and this adds to the sharing of information. 
TABLE 25

KNOWLEDGE OF ENTITLEMENTS IN RELATION TO PLACE OF ORIGIN

(\%)

\begin{tabular}{|c|c|c|c|c|c|c|c|}
\hline \multirow[t]{2}{*}{ Whe orom } & \multirow[b]{2}{*}{ o } & \multicolumn{2}{|c|}{ 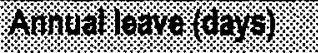 } & \multicolumn{2}{|c|}{ 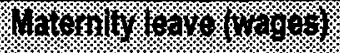 } & \multicolumn{2}{|c|}{ 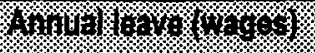 } \\
\hline & & $1010 \%$ & 1961\%. & Kinor. & 3.1919. & $4010 \%$ & 8. \\
\hline Factory & 78 & 20.5 & 79.5 & 21.8 & 78.2 & 11.8 & 88.2 \\
\hline west Java & 33 & 30.3 & 69.7 & 12.1 & 87.9 & 15.2 & 84.8 \\
\hline Other Java & 116 & 49.7 & 54.3 & 39.7 & 60.3 & 39.7 & $\overline{60.3}$ \\
\hline Other islands & 27 & 37 & 63 & 37 & 63 & 29.6 & 70.4 \\
\hline
\end{tabular}

In Table 26, except for the age group of 30-34 years old, the level of awareness increases with age. Table 27 illustrates the relationship between the level of education of the respondents and their awareness of the rules and regulations, especially regarding UMR, yearly holiday entitlements and holiday pay. It shows that by and large, the level of awareness of rules and regulations increases with a worker's educational level. Finally, it can be observed that the level of awareness also increases with the length of employment (Table 28).

TABLE 26

\section{KNOWLEDGE OF ENTITLEMENTS IN RELATION TO AGE}

(\%)

\begin{tabular}{|c|c|c|c|c|c|c|c|c|c|}
\hline \multirow[b]{2}{*}{ 48E. } & \multirow[b]{2}{*}{ \% } & \multicolumn{2}{|c|}{ Hong } & \multicolumn{2}{|c|}{ (1) } & \multicolumn{2}{|c|}{ 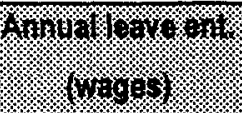 } & \multicolumn{2}{|c|}{ 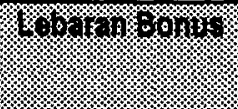 } \\
\hline & & $1190 \%$ & 8\%orit: & $4 \%$ & $890 \%$. & 19\% & 4801\% & 6 & $\frac{8}{8.10}$ \\
\hline $15-19$ & 65 & 16.9 & 83.1 & 18.5 & 81.5 & 7.7 & 92.3 & 10.8 & 89.2 \\
\hline $20-24$ & 109 & 37.6 & 62.4 & 41.3 & 58.7 & 34.9 & 65.1 & 32.1 & 67.9 \\
\hline $25-29$ & 47 & 34.0 & 66.0 & 42.6 & 57.4 & 34.8 & 66.0 & 31.9 & 68.1 \\
\hline $30-34$ & 15 & 33.3 & 66.7 & 26.7 & 73.3 & 13.3 & 86.7 & 20.0 & 80.0 \\
\hline$>35$ & 18 & 44.4 & 55.6 & 44.4 & 55.6 & 38.9 & 61.1 & 33.3 & 66.7 \\
\hline
\end{tabular}


TABLE 27

\section{KNOWLEDGE OF ENTITLEMENTS IN RELATION TO EDUCATIONAL LEVEL}

$(\%)$

\begin{tabular}{|c|c|c|c|c|c|c|c|}
\hline \multirow[t]{2}{*}{ 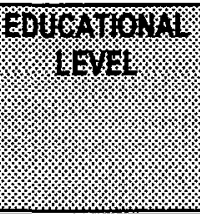 } & \multirow[t]{2}{*}{$\%$} & \multicolumn{2}{|c|}{$8 \%$} & \multicolumn{2}{|c|}{ 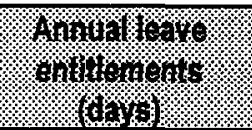 } & \multicolumn{2}{|c|}{ 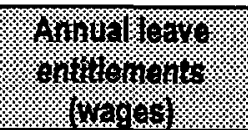 } \\
\hline & & $164 \%$ & 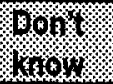 & $41110 \%$ & 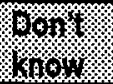 & $11101 \%$ & Bront \\
\hline SD & 92 & 30.43 & 69.57 & 17.4 & 82.6 & 13.0 & 87.0 \\
\hline SMPU & 83 & 37.34 & 62.66 & 34.9 & 65.1 & 26.5 & 73.5 \\
\hline SMAU & 39 & 53.84 & 46.16 & 51.3 & 48.7 & 30.8 & 69.2 \\
\hline SMAK & 38 & 55.26 & 44.74 & 63.2 & 36.8 & 55.3 & 44.7 \\
\hline$>$ SMA & 2 & 100.0 & 0 & - & 100.0 & 50.0 & 50.0 \\
\hline
\end{tabular}

TABLE 28

\section{KNOWLEDGE OF ENTITLEMENTS IN RELATION TO \\ LENGTH OF EMPLOYMENT}

(\%)

\begin{tabular}{|c|c|c|c|c|c|c|c|c|c|}
\hline \multirow[t]{2}{*}{ /. } & \multirow[t]{2}{*}{ 获 } & \multicolumn{2}{|c|}{ / } & \multicolumn{2}{|c|}{ 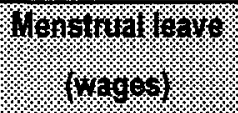 } & \multicolumn{2}{|c|}{ lon } & \multicolumn{2}{|c|}{ finnugloury. } \\
\hline & & 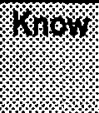 & $\sqrt{160100}$ & mion & \%or & (1, & 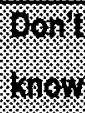 & $4810 \%$ & 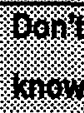 \\
\hline$<1$ year & 62 & 19.4 & 80.6 & 17.7 & 82.3 & 14.5 & 88.5 & 16.1 & 83.9 \\
\hline $1-3$ years & 113 & 31.9 & 68.1 & 23 & 77 & 28.3 & 71.7 & 30.1 & 69.9 \\
\hline $4-7$ years & 55 & 36.4 & 63.6 & 34.5 & 65.5 & 38.2 & 61.8 & 23.6 & 76.4 \\
\hline$>7$ years & 24 & 54.2 & 45.8 & 50 & 50 & 62.5 & 37.5 & 45.8 & 54.2 \\
\hline
\end{tabular}




\section{V.6. Migration and Poverty Alleviation}

Most of the permanent workers (78 percent) say that their parents live in a village. These respondents thus form part of the flow of workers from the rural areas to the cities, and the substitution of agricultural occupation in favor of the industrial sector. Both the lack of opportunity to work and the relatively lower wages in rural areas "push" women to look for work in the urban area. The respondents are mostly from West Java, Central Java, East Java and some provinces in Sumatra and Nusa Tenggara. Distance does not seem to be a hindrance to migration. Workers are willing to move long distances to go to areas where wages are higher. Economic motives are the strongest 'push' factor for women to migrate. These women workers contribute to sustaining their families back in their hometown: 69 percent of them indicate that they help their families financially. According to 75 percent of the respondents, they sent less than Rp 50,000 in the month prior to being interviewed. These financial contributions are being used by their parents to buy food ( 23 percent), household essentials (19 percent) and to pay for sibling's education (12 percent). The remaining money is used to maintain their plot of agriculture land. Almost all the respondents pay debts. Most (94 percent) do not receive any financial support from their family as they are generally embarrassed to ask for help since working is perceived as meaning being independent.

The results indicate that even out of their small salaries, industrial workers support their families' needs by augmenting their consumption as well as by financing their investments (both in human capital and other forms of capital, such as land, housing). Thus, it would not be surprising to find that for these respondents, migrating to cities and finding work in the industrial sector is a means of alleviating poverty, both of existing and future generations. The investment in education might yield some hope for economic improvement for the family, since education opens the door to better paying jobs.

The most popular savings method among the respondents is 'arisan' or the rotating lottery. The amount put aside for savings is between $\operatorname{Rp} 1,500$ to $\operatorname{Rp} 150,000$, with the actual amount being determined by their education, their hometown, and their type of accommodation. Table 29 illustrates the increase in the ability to save with the increase in education. The respondents from outside Java, due to their distance, save more than their counterparts from Java. Their ability to save declines for the women when they are living with their parents. This is because their earnings are then used to help with household needs. 
TABLE 29

\section{SAVING ABILITY IN RELATION TO EDUCATIONAL LEVEL, PLACE OF ORIGIN, AND LIVING ARRANGEMENT}

$(\%)$

\begin{tabular}{|l|c|c|c|}
\hline $\begin{array}{l}\text { 1.Educational } \\
\text { Level }\end{array}$ & & & \\
\hline SD & 92 & 58.7 & 41.3 \\
\hline SMPU & 83 & 68.7 & 31.3 \\
\hline SMAU & 39 & 82.1 & 17.9 \\
\hline SMAK & 38 & 81.6 & 10.4 \\
\hline$>$ SMA & 2 & 100.0 & - \\
\hline & & & \\
\hline 2. Place of Origin & & & 43.6 \\
\hline factory & 78 & 56.4 & 30.3 \\
\hline West Java & 33 & 69.7 & 25.0 \\
\hline Other Java & 116 & 75.0 & 18.5 \\
\hline Other Island & 27 & 81.5 & \\
\hline & & & \\
\hline 3. Living \\
Arrangement & & & 33.3 \\
\hline Dormitory & 15 & 66.7 & 51.1 \\
\hline With parents & 47 & 48.9 & 37.5 \\
\hline Husband & 32 & 62.5 & 22.4 \\
\hline Rent & 125 & 77.6 & 20.0 \\
\hline Relatives & 20 & 80.0 & 42.9 \\
\hline With owners & 7 & 57.1 & \\
\hline
\end{tabular}

The pattern of migration suggests the mere fulfillment of basic needs is the main purpose for migration: 49 percent of the respondents who are permanent workers say they would prefer to be home since the only reason for moving away was to earn money. Only 30 percent of the respondents plan to stay to where they migrated and 21 percent have not decided if they will stay or return home. Many also still go home for visits with 90 percent saying they have visited their hometown with various frequencies: 79 percent visit at least once a year. A further relationship between workers and their origin is shown by the fact that workers from the same place tend to live in the same area. 


\section{V.7. Labor Union (SPSI)}

In 1985, the Ministry of Labor ruled that the 21 existing trade unions be merged into 9 departments under SPSI. The structural change amounts to a change from a federation to a unitary model. The consequence of this change is that SPSI is the only organization approved by the government, and the formation of other workers' organizations is not authorized. Thus, it is clear why 83 percent of the respondents indicate that they do not belong to other organizations besides SPSI, 60 percent say there is a SPSI chapter in their work place, whereas 30 percent say there is no SPSI and 10 percent do not know. Out of the respondents who are aware of SPSI, 85 percent say they are a member. However, only 53 percent of them say their working conditions have improved due to SPSI's presence whereas the other 47 percent do not think SPSI has improved their wages nor their benefits (Table 30).

The SPSI membership differs with the size of the company. The relationship is illustrated in Table 31, with the workers from large-scale companies more likely to join than those from the small and medium-sized companies. Only nine percent of the workers from small and medium-sized companies are members of the SPSI compared to 69 percent in the large-scale companies.

TABLE 30

\section{UNION MEMBERSHIP}

$(\%)$

\begin{tabular}{|l|l|l|l|l|}
\hline & I. \\
\hline $\begin{array}{l}\text { Membership with workers organizations other } \\
\text { than SPSI }\end{array}$ & 254 & 16.9 & 83.1 & - \\
\hline SPSI in the workplace & 254 & 60.2 & 30.3 & 9.4 \\
\hline SPSI membership & 153 & 85.0 & 15.0 & - \\
\hline SPSI role in relation wages and benefits & 153 & 52.9 & 47.1 & - \\
\hline Collective Labor Agreement & 254 & 55.9 & 26.0 & 18.1 \\
\hline
\end{tabular}


TABLE 31

SPSI MEMBERSHIP IN RELATION TO COMPANY SIZE

(\%)

\begin{tabular}{|c|c|c|c|c|}
\hline \multirow[t]{2}{*}{ 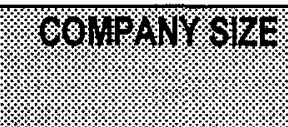 } & \multirow[t]{2}{*}{ \% } & \multicolumn{3}{|c|}{$5 \%$} \\
\hline & & $1 / 18$ & $1 \%$ & $304 \% 4181$ \\
\hline$<20-100$ & 35 & 8.6 & 82.9 & 8.6 \\
\hline$>100$ & 219 & 68.5 & 21.9 & 9.6 \\
\hline
\end{tabular}

Out of the women workers with a permanent status, 56 percent know that there is a collective labor agreement or Kesepakatan Kerja Bersama (KKB), while 26 percent say there is no agreement and 18 percent are not aware of it. However, only 28 percent of them understand the content fully, 44 percent understand partly, and 28 percent do not understand the content at all.

In terms of the effectiveness of $\mathrm{KKB}, 44$ percent of the respondents believe that $\mathrm{KKB}$ has some influence on their work condition, 19 percent say it does not influence the conditions, 16 percent say it somewhat influences the conditions and 21 percent do not know.

\section{V.8. Workers' Aspirations}

Even though this survey does not elaborate on workers' aspirations, it reflects the workers' hopes and expectations to some extent. For instance, 53 percent state that their general situation is comparable to the situation in other places; 37 percent say their situation is better, and 10 percent say their situation is worse. However, the majority, or 63 percent, feel that their situation now has improved compared to two years ago, 29 percent feel it is the same and eight percent say their situation has deteriorated. The workers attribute the improvement in conditions to the UMR (regional minimum wage) which is reasonably higher than the previous years. This data reflects the positive attitude of young women towards their current jobs. The ability to earn a living, and the independence which that brings with it, are the main reasons for their perceived improvement in their livelihood compared to two years ago. 
In terms of hopes for improvement, 90 percent of the respondents hoped for improved benefits and supporting services such as health insurance and health services. In addition, 70 percent hoped for prenatal care and birth-control programs, and 50 percent would like day-care for their children. Other facilities desired are for dental and eye case services.

\section{Main Findings and Policy Recommendation}

The main findings of this survey can be summarized as follows. As with other studies, the main characteristics of the women workers surveyed are that they are mainly young, with 70 percent in the 15-24 age group, single and have less than three years work experience. This phenomenon does not necessarily mean that there is a high turnover of women workers. It simply reflects the reality that after marriage and having children, these women often do not go back to industrial work. Further, due to an abundant supply of labor, their positions are easily filled by others. It should be noted that the main difference between this study and others is the number of respondents (300), and that it is contemporary research which has the advantage of being undertaken after changes have occurred, in particular with regard to the minimum wage.

The main finding is that these is a mixed record with regard to the success of government stipulated regulations in terms of compliance, workers' knowledge, and effectiveness. This implies that government regulations and the government approach to policy need to be reevaluated, including consideration of workers' awareness of their rights, particularly to enable "self regulation" and thereby for companies to improve compliance to labor legislation. Clearly, in line with Agrawal (1995) the role of the labor union needs to be reviewed .

More specifically, if we go back to the five main questions raised by this study, the main findings and their policy implications are as follows.

\section{VI.1 Minimum Wages}

The minimum wage legislation which has received a great deal of attention since 1993 appears to have a high compliance rate ( 80 per cent) among the respondents, especially with large companies and in two of the sectors, namely textiles and garments. As expected, a lower percentage of women workers in large scale companies (15 per cent) receive lower than the 
official minimum wage, compared with small-medium sized companies ( 54 per cent). The numbers of course fall when one expands the definition of minimum wage to include all allowances other than the basic wage. However, even with this broader definition, 43 per cent of small-medium sized companies still pay the women workers below minimum wage. Given that minimum wage issues have received a high profile in recent years, it is not surprising that it is also the legislation that most of the women workers are aware of.

This finding combined with observations made by Agrawal (1995) raises several policy implications regarding minimum wages. As Agrawal points out (1995), the recent increases in minimum wages have set the minimum wage at unrealistically high levels as evidenced by the fact that the minimum wage is half of the average manufacturing wage (a much higher ratio than other countries), and set at an average of four times higher than the poverty line. The finding of this study is that payment of minimum wages is related to capacity and resources of company. Thus, the question arises as to whether the government should regulate in a centrally determined manner the minimum wage and whether the minimum wage should apply as broadly as it does now.

If minimum wage legislation is to be maintained, then it should be ensured that the increases are realistic. There has been increased concern and evidence that the rise in minimum wages have substantially raised the labor cost for companies in the labor intensive sectors in an unexpected manner. This has led to closures of smaller firms, substitution away from labor intensive production to using more automation, and reduction of non-wage compensation not defined as part of minimum wages. The higher wage costs could lead to higher unemployment. It also needs to be kept in mind that minimum wages are likely only to benefit the existing workers in the formal and industrial sector. Thus the minimum wage legislation is not effective in dealing with the poverty issue, especially in the informal and rural sectors. Other policies rather than minimum wages will be needed.

An equally important implication is whether the minimum wage should be applied as broadly as it does now, for all sectors and for all types of workers. The alternative is to have differential minimum wage rates between size of company, type of industry, type of workers, and location of the industry. Other countries that have legislated minimum wages, do not have comprehensive coverage but allow exclusions based on size and location (e.g. in bonded zone), and also allow a greater number of non wage benefits as part of the minimum wage (Agrawal, 1995). In the U.S. the legislated minimum wage is applicable only to large businesses and 
certain types of employees who are likely to be discriminated against (students, trainees or handicapped workers) are exempted. The U.S. also allows the cost of boarding as part of the minimum wage. Thus, consideration should be given as to whether minimum wage legislation should only be implemented by large companies and to permanent workers. One should also be aware of the limitations of administrative capacity in implementing the minimum wage policy, so that such a selective policy will need to be based on a very clear and transparent criteria.

\section{VI.2 Compliance With Labor Legislation}

Secondly the level of company compliance found in this research indicates that companies are complying with legislation regarding maternity leave and hours worked. Low compliance is found with regard to breast feeding facilities, menstrual leave and overtime pay rates. Differences in compliance can be found based on the size of the company.

In the case of menstrual leave, companies generally "buy" the two days leave entitlement by paying for the two days leave and the two days worked. Companies will often also not pay for the two days that women workers do not come in, pushing the incentive system to force women to work on the two days. Thus the policy does not achieve its objective and could in fact be seen as increasing the cost of women workers compared to men. A better policy is to allow all workers two days paid sick leave.

A matter of great concern is the non compliance to overtime rates since the bulk of respondents work over time ( 77 per cent), but only 30 per cent receive the regulated over time rates. In this case the bargaining power lies more with the company as workers will take every opportunity to increase their earnings, even if the overtime pay is small or less than regulated. One can also raise the following questions: whether the unrealistic increase in minimum wages and thus in costs to companies, has also led to companies trying to lower costs elsewhere, such as non compliance on over time rates? Has there been too much attention to minimum wages, including by the government authorities who monitor the enforcement of labor legislation, so that companies, especially the more vulnerable and visible big companies ensure that they comply to this and less to the other policies?

A large percentage of women workers (63 per cent) also indicate that they participate in the social security program JAMSOSTEK. However, it is certainly too early to tell whether they will in fact enjoy these benefits when most of them only work for three years in the company. 


\section{3 Health and Safety Provisions}

A similar trend can be found in the provision of health and safety precautions. Provision of basic health facilities and protective gear vary by size of company, with a lower percentage of provision by smaller and medium sized companies. Once again this is related to the capacity of the company. However, an important finding is that all companies, irrespective of size, do not take some basic safety precautions, such as having a fire drill. Furthermore, a high percentage of all workers ( 60 per cent) indicate that they experience health problems related to work, yet a low percentage use the health facilities provided and there is low absenteeism.

The gap between the health and safety provisions and what is implemented needs to be evaluated. Is it due to ineffective implementation of the government policies? Is it due to workers' lack of knowledge and lack of a mechanism to voice their demands for what is rightfully due to them? Furthermore, companies' violation of basic safety provisions such as a fire drill could also imply not just ineffectiveness of the monitoring of the policy, but also the lack of sanctions in the case of violation. Fire drills and protective gear are a necessary preventive step; one should not wait for the fire or accident to happen before steps are taken.

\section{V1.4 Knowledge of Standard Working Conditions, Wages and Benefits}

The finding is that in general workers have a poor knowledge of the standard working conditions, wages and benefits that they should receive. The knowledge level is highest for the workers who have longer work experience and higher education attainment. Not surprisingly, given the attention it has been given in the last few years, the highest awareness is found with regard to the minimum wage. The benefits such as breast feeding facilities and overtime wage rates which have low compliance rates are also the ones where workers have a minimum of knowledge. However, it is not possible to conclude that the lack of knowledge is the cause of lack of compliance since there are other benefits where there is high compliance and relatively lower knowledge of workers such as maternity leave, yearly holidays and bonus, and so on. Thus, it would appear that the reason for the high compliance is not due to the workers' knowledge, but more to do with the focus by officials that implement or monitor the policy. A clear example is minimum wage policy due to the high profile it has received. This points to a 
concern that the compliance is more related to issues that are identified as priority by the government officials, for whatever reason, rather than by the workers.

There needs to be more attention paid to raising the awareness and the knowledge of workers of their rightful working conditions, benefits and rights. Agrawal (1995) calls this avenue the "self-regulation" of companies. However, awareness alone is not sufficient--there has to be a mechanism for grievances to be addressed in a balanced and transparent way so that incidents such as labor unrest do not also become prevalent. One sound avenue is reevaluating the role of trade unions.

\section{VI.5 Role of Trade Unions and Workers' Aspirations}

The survey finds, not surprisingly, that 60 per cent of the women workers indicate that there is an SPSI chapter and that most ( 85 per cent) are members. However, only 53 per cent say that their working conditions (including wages and benefits) have improved with the presence of SPSI. Membership is also much more prevalent in the large sized companies. Only 9 per cent of workers from small and medium sized companies are members of SPSI compared with 69 per cent in the large sized companies. Thus, to the extent that SPSI is effective in ensuring better working conditions and benefits, the interests of women workers in small and medium sized companies are under represented. Further analysis is needed as to whether the lower than desired unionized rate is due to the present government sanctioned one labor union policy. One needs to analyze what will happen if this sanction is lifted and whether a freer setting up of labor unions will represent workers' interests better and whether the interests of workers in small and medium enterprises will be protected.

\section{Concluding Notes}

This study can be considered as a preliminary one that has provided some important insights into the effectiveness of laws and regulations in ensuring adequate compensation and conditions for women working in the formal industrial sector in Indonesia. In particular, the study focused on three export oriented sectors where 45 percent of women workers can be found out of the total number of women working in the manufacturing industry (1993 Survey Industry), mainly in medium and large scale companies (i.e. formal sector). 
One of the main conclusions is that there maybe too much emphasis on minimum wage legislation at the expense of the implementation of more important aspects of labor legislation and regulations. Some of the important aspects raised in this study include adequate compensation for overtime and the regularity and security of income. On safety and health, the emphasis has been on provision rather than, for example, on training and nutrition.

In order to improve the study so that there is more confidence that the results represent the conditions faced by women workers, the sample size should be chosen based on the sectors where there is a greater number of women employed. For instance, we could expand the sample to include electronics which while only absorbing 3.3 percent of total women workers has a predominantly female workforce ( 52 percent of workers are women) and is a potentially important labor intensive export oriented sector. Furthermore, it should be investigated whether there is a large representation of women workers in small and cottage industries. This will enrich the study by not only capturing the possibility of a greater representation of women in the smaller companies, but also enabling better comparisons with regard to differences in analysis relating to the scale of the company.

From the outset, this study was not intended to answer the gender issue of whether there are differences in compensation and conditions facing women workers compared with men workers. Nevertheless, many of the inputs regarding this study highlighted the lack of focus on gender. This study was only able to make some inferences with regard to the different legislation affecting women and its impact - namely that this legislation tended to make it more costly to hire women rather than protecting women. In the near future, it will be important to address the gender issue as a follow up to the Women's Conference in Beijing last year. Furthermore, whilst studies at the aggregate level indicate that differences in earnings between men and women workers are declining, there is still a difference that cannot be explained by variation in education alone (Agrawal, 1996). Ultimately, the equality of treatment for women and the advancement of women is not just an important human rights issue, but also that of economic efficiency.

Thus, it is recommended that future research involving collection of primary data such as this one be conducted to attempt to answer the gender and job segregation issue. With regard to addressing the gender issue, the challenge will be in finding comparable equal work between women and men. Of course one way to get around the problem is to find ways to evaluate equal pay for 'work of equal value' and this will be one issue challenging future research. 
Another unanswered issue is job segregation between men and women workers. It is true that women workers end up doing the menial and unskilled tasks or the least pay work, while men do the more skilled tasks or higher pay work. A close analysis of job segregation will necessitate data on occupation by gender and sector.

The study was inconclusive in finding the relationship between migration of women workers and alleviation of poverty. This mainly related to the way the questions were asked and also the small sample size. Therefore improving the results will necessitate reframing the questions and enlarging the sample size.

A final point can be made with regard to improving the conduct of such studies in future. First is to obtain as much input as possible from the various non-governmental organizations and institutions that work on issues related to women workers early on in the stage of research and questionnaire design. Second is to devote more effort and pilot testing of the questionnaire. 


\section{References}

Agrawal, N. (1995), Indonesia: Labor Market Policies and International Competitiveness, World Bank Policy Research Working Paper, No. 1515, Washington D.C.

Agrawal, N. (1996), "The Benefits of Growth for Indonesian Workers", World Bank Policy Research Working Paper, No. 1637, Washington D.C.

Anaf, A. (1986), Female Migration and Employment: A Case Study in Kecamatan Pasar Rebo, Jakarta. National Institute of Economic and Social Research, Jakarta.

Booth, A. (1994), "Repelita VI and the Second Long-Term Development Plan". Bulletin of Indonesian Economic Studies, Vol. 30 No. 3, December 1994.

Bukit, D \& Z. Bakir (1984), Partisipasi Angkatan Kerja Indonesia: Partisipasi, Kesempatan, dan Pengangguran (Indonesia's Labor Force, Participation, Opportunity and Unemployment). Jakarta, CV Rajawali.

Cox Edwards, A., (1996), "Labor Regulations and Industrial Relations in Indonesia", World Bank Policy Research Working Paper, Number 1640, Washington D.C.

Dufty, N.F (1984), Industrial Relations in the Pilbara Iron Ore Industry. Social Science Research Centre, Western Australia Institute of Technology, Perth.

Danzinger, N (1983), "Sex-related Differences I the Aspirations of High School Students". In Sex Role, Vol. 9 No. 6.

De Yong, G. and Robert W. Gardner (ed.) (1981), Migration Decision Making; Multidisiplinary Approach to Microlevel Studies in Developed and Developing Countries. Pergamon Press, New York.

Freeman, Richards (1993), "Does Suppression of Labor Contribute to Economic Success? Labor Relation and Markets in East Asia". Unpublished Monograph. 
Freidmann, J. (1996), Empowerment: The Politics of Alternative Development, USA.

Freire, P. (1990), Pedagogy of the Oppressed. Penguin.

Gardiner, M.O. (1993), “A Gender Perspective on Indonesia's Labour Market Transformation”. In Chris Manning and Joan Hardjono (edit.), Indonesia Assessment 1993: Labour Sharing in the Benefits of Growth, Political and Social Change, Monograph No. 20, Research School of Pacific Studies, ANU, Canberra.

Grijns, M. et. al. (ed.) (1992), Gender, Marginalisation and Rural Industries, West Java Rural Nonfarm Sector Research Project. Project Research Report Series No. RB-7, Akatiga Foundation, Bandung.

Grijns, M. and Van Velzen (1993), "Working Women: Differentiation and Marginalisation". In Chris Manning and Joan Hardjono (edit.), Indonesia Assessment 1993: Labour Sharing in the Benefits of Growth, Political and Social Change, Monograph No. 20, Research School of Pacific Studies, ANU, Canberra.

Handayani, S. (1995), "Sri Rejeki: Buruh Pabrik Utama Tex" ( Sri Rejeki: Women Worker in Utama Tex Factory), in M. Singarimbun and S. Sairin (ed.), Lika-liku Kehidupan Buruh Perempuan (The History of Women Worker's life), Yayasan Annisa Swasti, Yogyakarta.

Heyzer, N. (1988), Daughters of Industry: Work, Skills and Consciousness of Women Workers in Asia. Kuala Lumpur, APDC.

Hill, H. (1991), "The Emperor's Clothes Can Now Be Made in Indonesia". Bulletin of Indonesian Economic Studies, Vol. 27 No. 3, Research School of Pacific Studies, Australian National University, p. 89-128.

Hugo, G.J. et. al. (1990), The Demographic Dimension in Indonesian Development. Oxford University Press Pte. Ltd., Singapore. 
ILO (1992), Wage Policy. ILO Office, Geneva.

Indraswari (1995), “The Impact of Industrial Restructuring on Women Workers in Indonesia", in Sister Helene O' Sullivan, M.M. (ed.), Silk and Steel: Asia Woman Workers Confront Challenges of Industrial Restructuring, Committee for Asian Women, Hong Kong.

Joekes, S. (1987), Women in the Third World Economy. In STRAW, Oxford, Oxford University Press.

Khoo, S.E. (1982), "Urbanward Migration and Employment of Women in Southeast and East Asian Cities: Pattern and Policy Issues". A Seminar Paper on Women in the Urban and Industrial Workforce, Southeast and East Asia, Manila.

Lok, H.P. (1993), "Labour in the Garment Industry: An Employer's Perspective", in Chris Manning, and Joan Hardjono (ed.), Indonesia Assessment 1993: Labour Sharing in the Benefits of Growth, Political and Social Change, Monograph No. 20, Research School of Pacific Studies, ANU, Canberra.

Manning, C. (1993), "Examining Both Sides of the Ledger: Economic Growth and Labor Welfare Under Soeharto", in Chris Manning, and Joan Hardjono (ed.), Indonesia Assessment 1993: Labour Sharing in the Benefits of Growth, Political and Social Change, Monograph No. 20, Research School of Pacific Studies, ANU, Canberra.

Manning, C. (1994), "What Happened to Wages in the New Order?" Bulletin of Indonesian Economic Studies, Vol. 30 No. 3, December 1994.

Mantra, I.B. (1981), Population Movement in Central Java, Gadjah Mada University Press, Yogyakarta.

Mc. Gee, T.G. (1971), The Urbanization Process in The Third World. G. Bell and sons, London. 
Molyneux, M. (1985), "Mobilization Without Emancipation? Women's Interests, The State, and Revolution in Nicaragua". Feminist Studies, 11 No. 2.

Nusantara, A.H.G., (1995), "Law and the Right to Organize" In Harris, D.R. (Edit) Prisoners of Progress: A Review of the Currents Indonesian Labor Situation, INDOC - FNV INFID, Amsterdam.

Poerwandari, K. (1995), "Aspirasi Perempuan Bekerja dan Aktualisasinya" (Aspiration of Women Workers and its Actualization). In Ihroni, T.O. (ed.) Kajian Wanita Dalam Pembangunan (The Assessment of Women in Development), Yayasan Obor Indonesia, Jakarta.

Rinakit, S.(1995), "Trade Union Problems and Labour Unrest in the New Order Era", forthcoming.

Scott, A. Mc Ewen (1986), "Women and Industrialization: Examining the Female Marginalisation". Thesis in The Journal of Development Studies 22 (4). pp 649-680.

Starr, G. (1981), “Minimum Wage Fixing”. ILO, Geneva.

Stoffer, S.A., (1960), "Intervening Opportunities and Completing Migrants". In Journal of Regional Science, 2 (1): 1-26.

Thadani, V. and M. Todaro (1978), "Towards A Theory of Female Migration in Developing Countries", A Population Council Working Paper, Centre For Policy Studies, New York.

Tjandraningsih, I. (1991), "Tenaga Kerja Pedesaan pada Industri Besar Sepatu Olah Raga untuk Ekspor" (Rural Workforce in Sports Shoes Industry), A Project Working Paper Series No. B-20, West Java Rural Nonfarm Sector Research Project (Proyek Penelitian Sektor Non Pertanian Pedesaan Jawa Barat), PSP-IPB ISS PPLH-ITB, Bandung. 
Triaswati, N. (1996), Women and Children Labor Force in Indonesia. Paper presented in Third ASEAN ISIS Colloquium: Human Rights, Labor and Refugees in ASEAN, Manila, February 1996.

Todaro, M.P. (1976), Internal Migration in Developing Countries. International Labour Office, Geneva.

United Nations (1986), "Report of the World Conference to Review and Appraise the Achievements of the United Nations Decade for Women: Equality, Development and Peace", New York.

United Nation (1989), "1989 World Survey on the Role of Women in Development", New York.

White, B. (1991), Studying Women and Rural Nonfarm Sector Development in West Java, A Project Working Paper Series No. B-12, West Java Rural Nonfarm Sector Research Project. PSP-IPB ISS PPLH-ITB, Bandung.

Wie, T.K. (1991), "The Surge of Asian NIC Investment into Indonesia". Bulletin of Indonesian Economic Studies, Vol. 27 No. 3, Research School of Pacific Studies, Australian National University, p. 55-88

Wolf, D. (1982), "Rural Females to The Factory: Household and Village Perspective From Central Java". A Seminar Paper on Women in the Urban and Industrial Workforce, Southeast and East Asia, Manila.

Wood, C.H. (1982), "Equilibrium and Historical-structural Perspectives on Migration". International Migration Review, 16.2, p. 298-319.

(1996), "Indonesian Women Workers: Problems and Issues", Working Group of Indonesian NGOs on the Women Workers Right, Bandung. 
FIGURE 1

RECEIPT OF ENTITLEMENTS IN RELATION TO COMPANY SIZE

(\%)

MATERNITY LEAVE ENT. (DAYS)
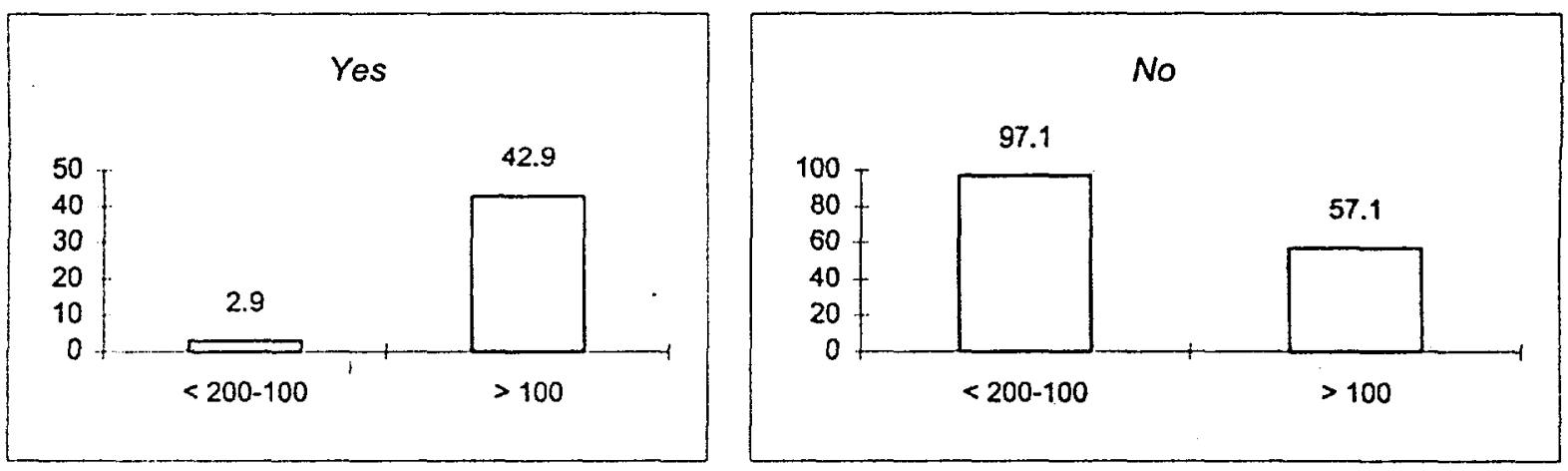

MATERNITY LEAVE ENT. (WAGES)
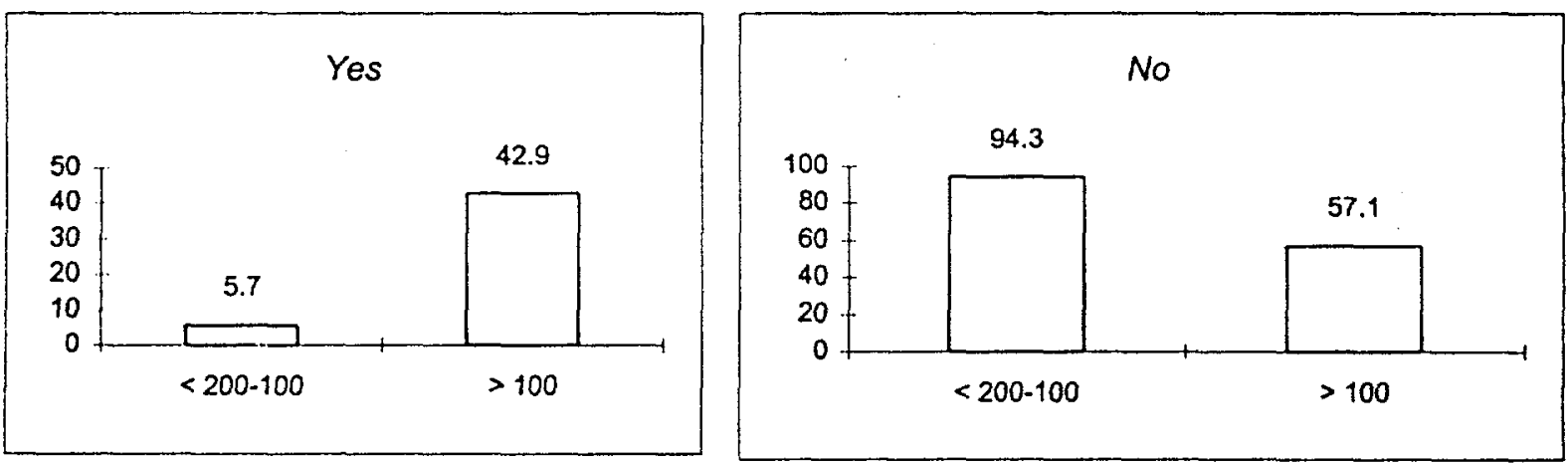

ANNUAL LEAVE ENT. (WAGES)
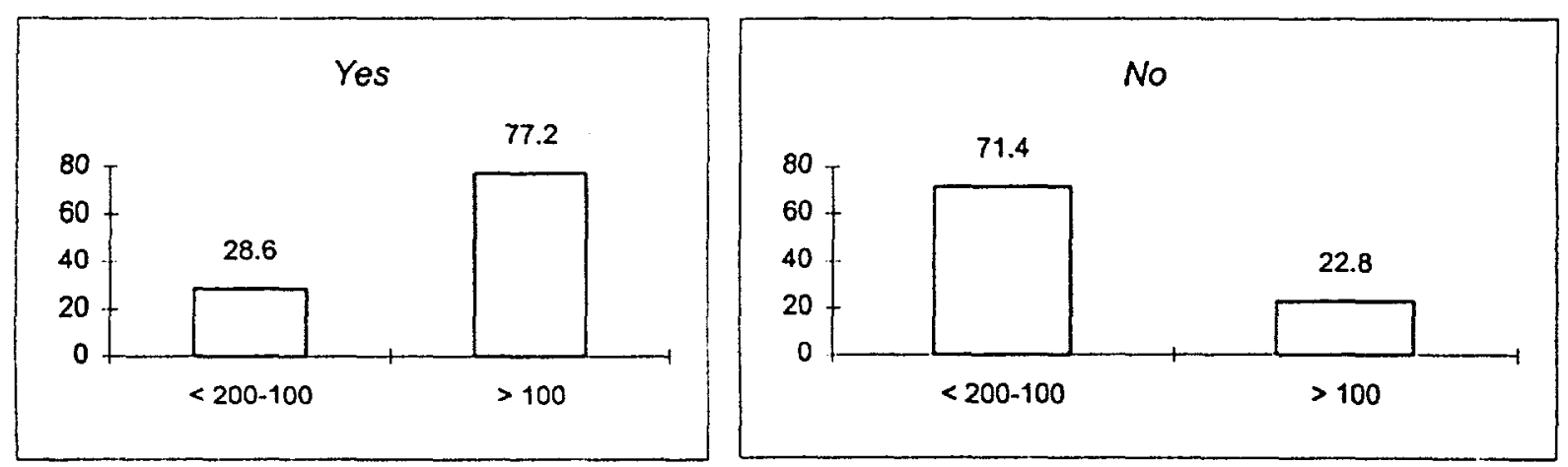


\section{LEBARAN BONUS}
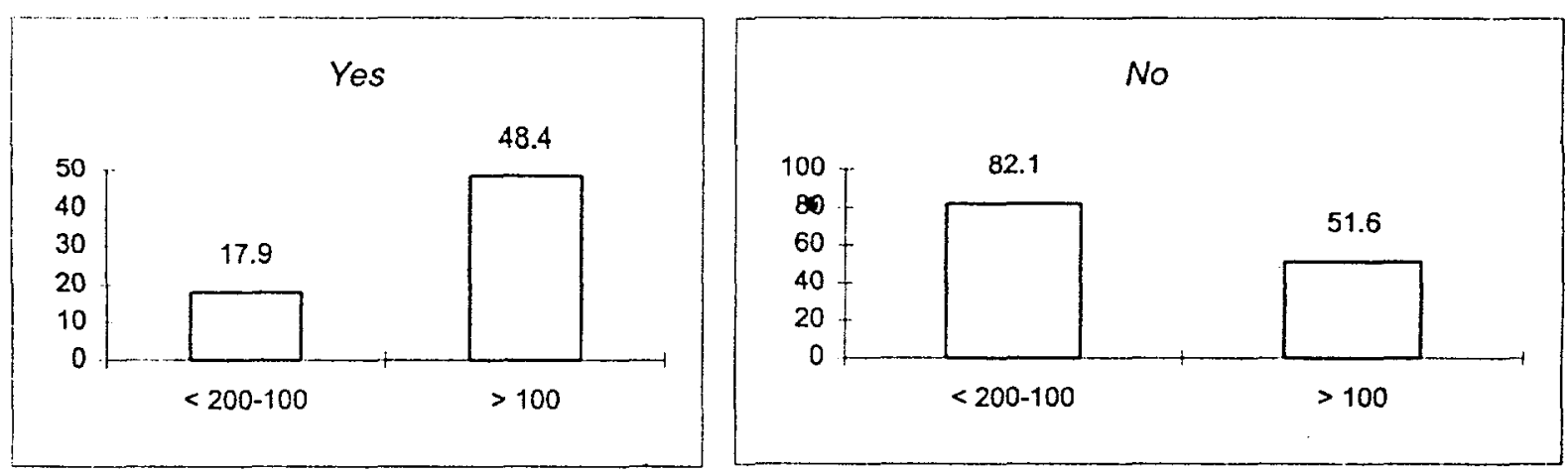

\section{OT FIRST HOUR}
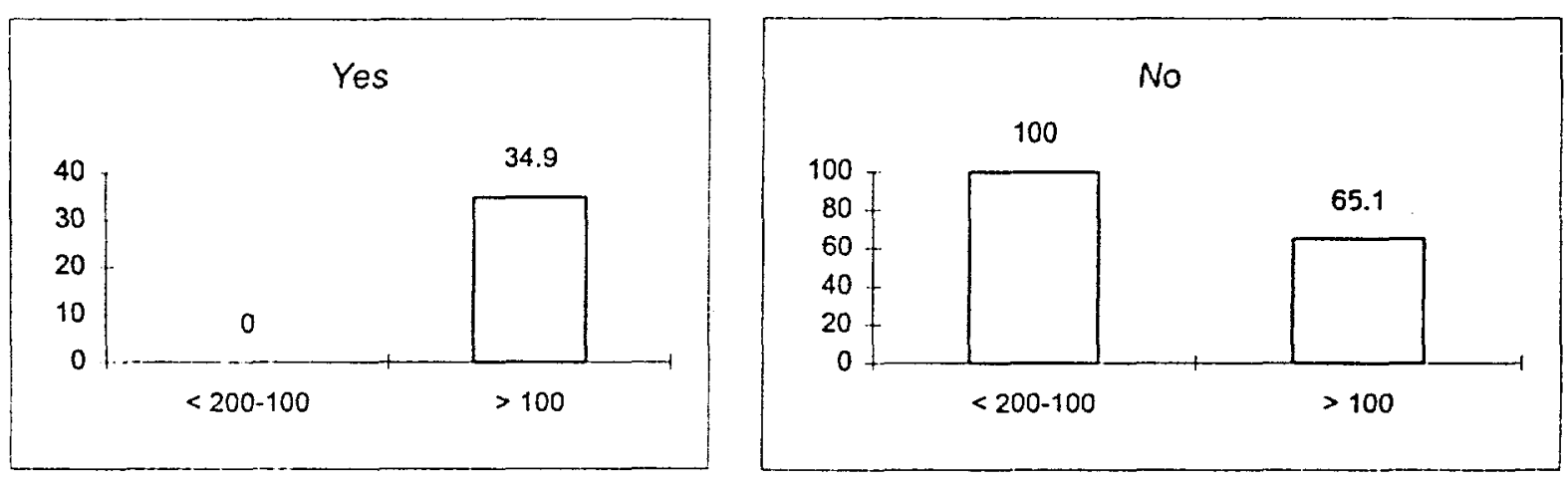

\section{OT SUBSEQUENT HOUR}
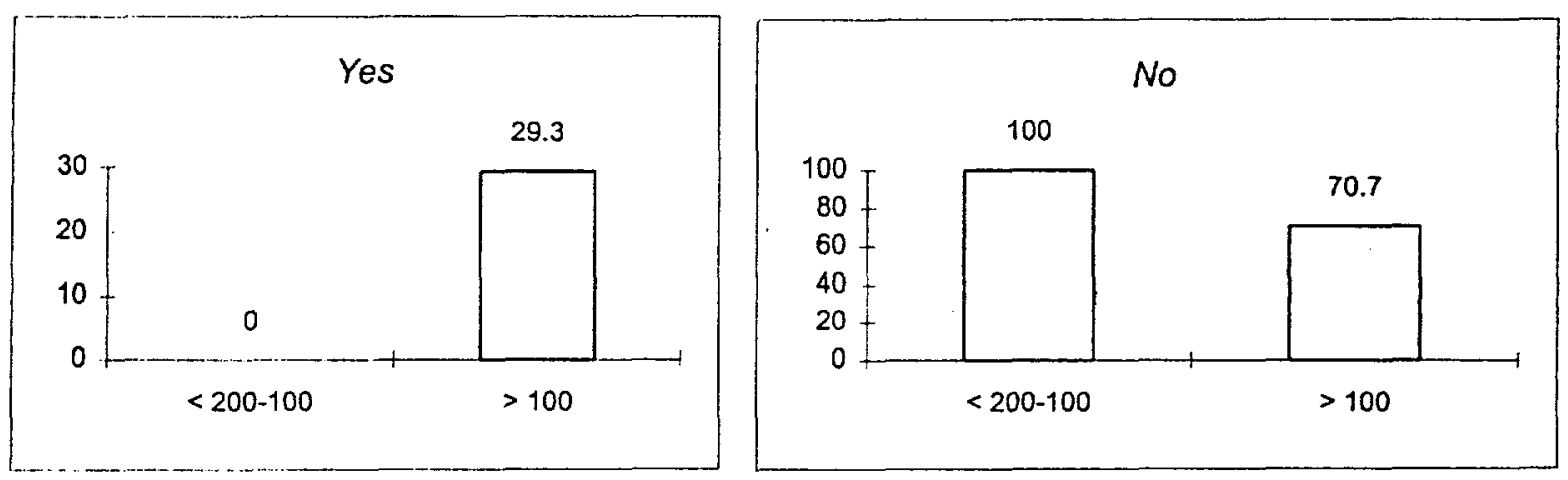


\section{ACCESS TO HEALTH AND SAFETY PROVISIONS}

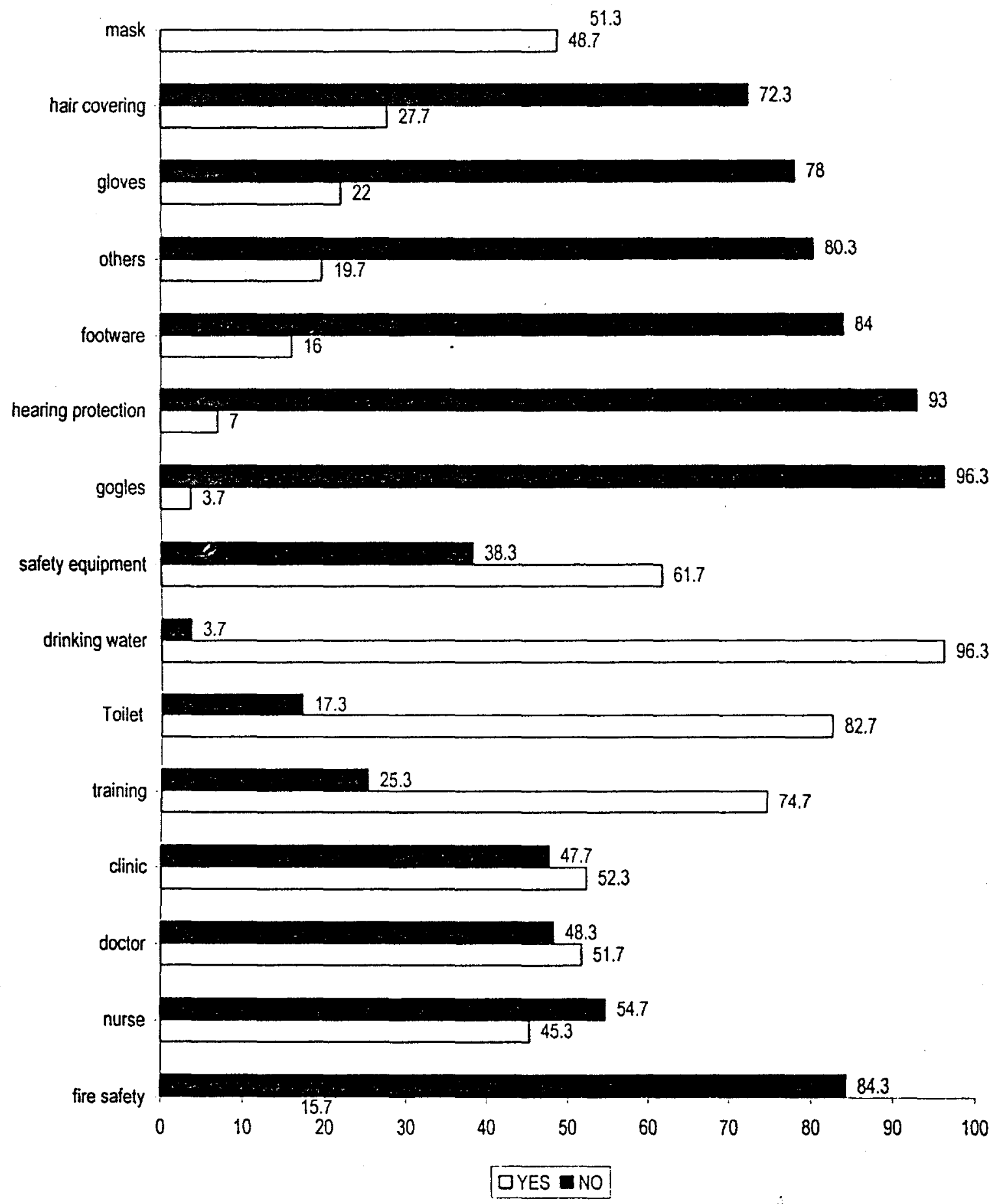


FIGURE 3

\section{ACCESS TO SAFETY EQUIPMENT IN RELATION TO COMPANY SIZ}

$(\%)$

\section{TOILET}
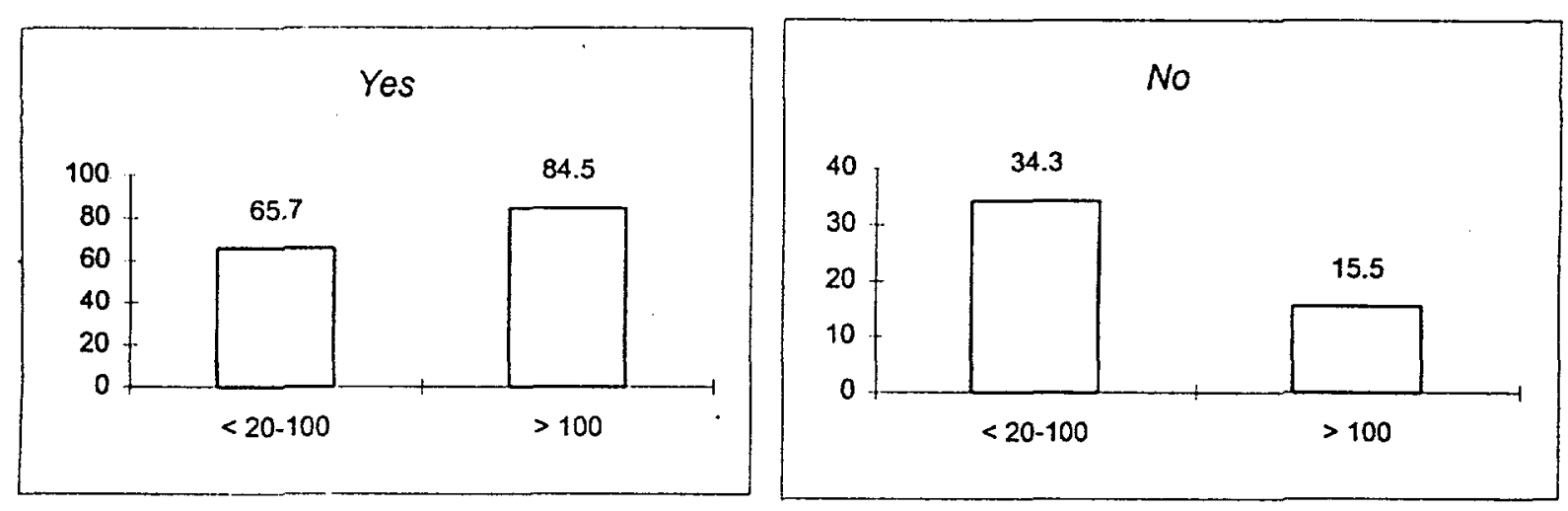

FIRST AID
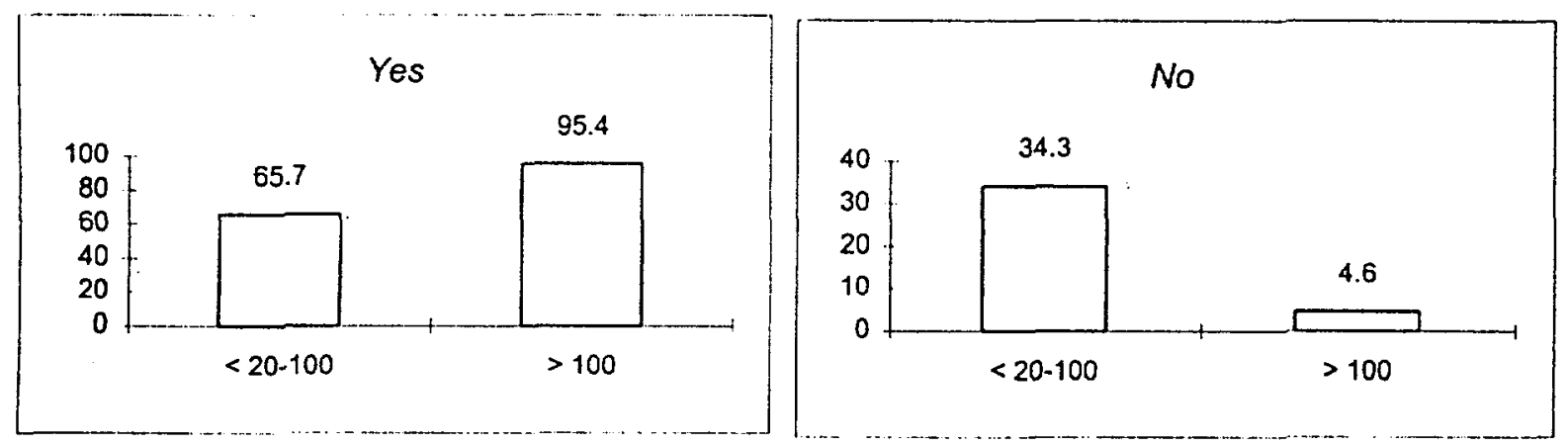

TRAINNING EQUIPMENT
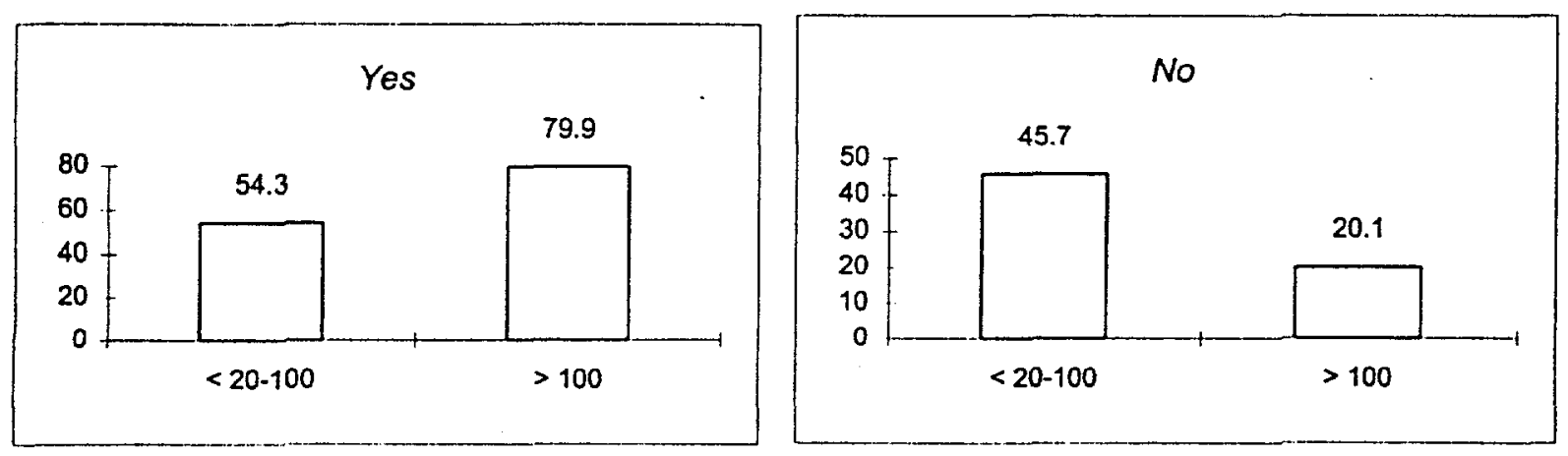


\section{HEALTH AND SAFETY EQUIPMENT}
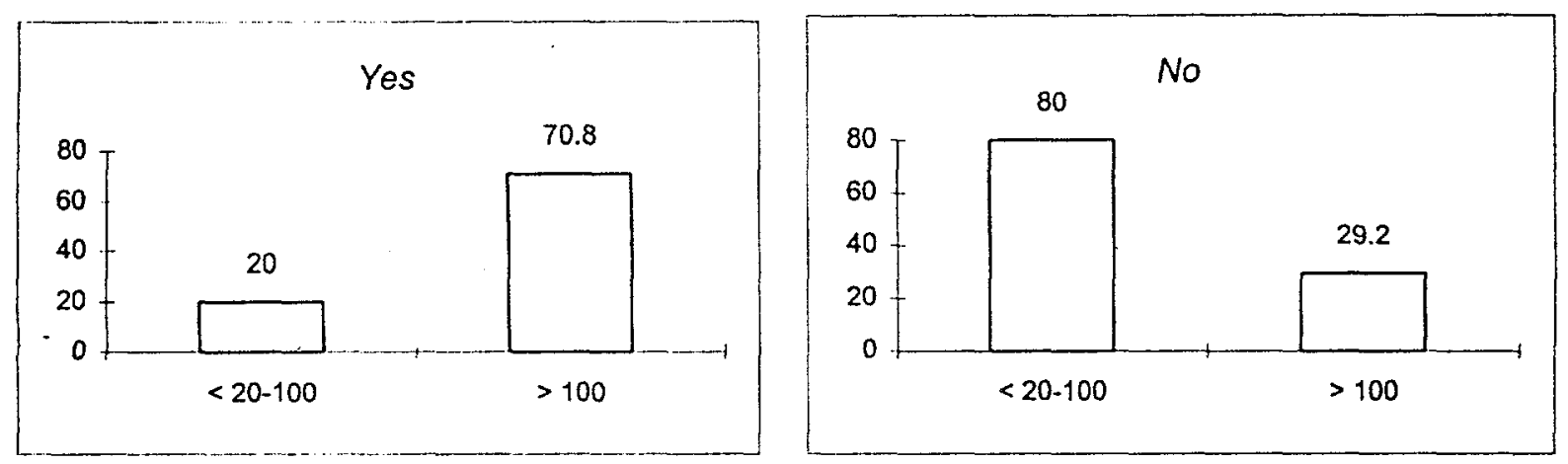

\section{CLINIC}
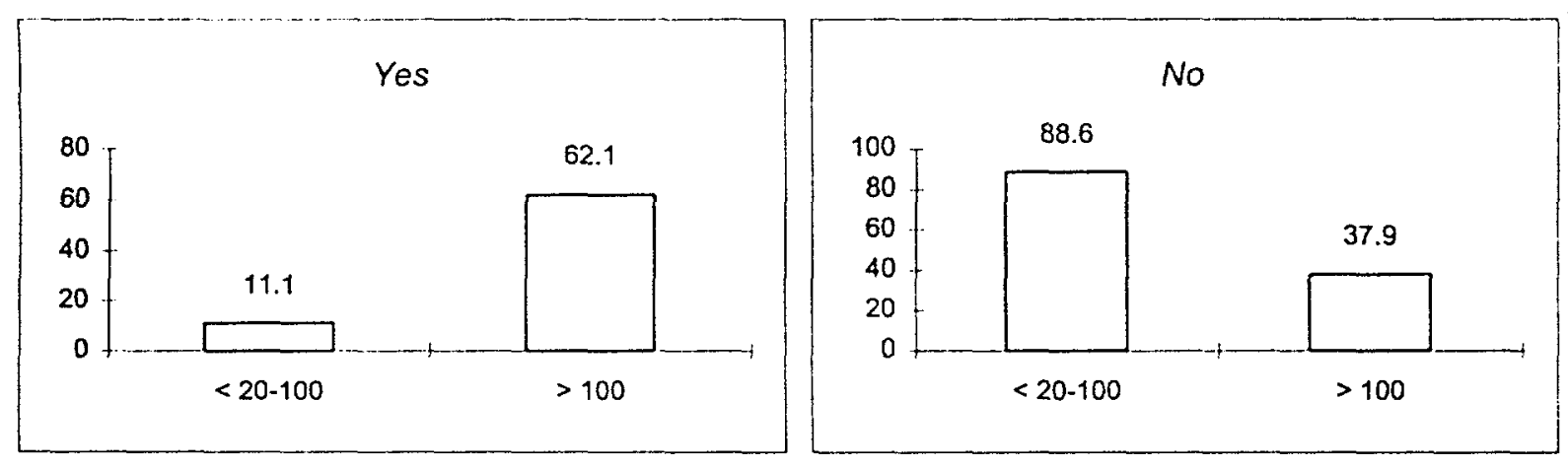

\section{NURSE}
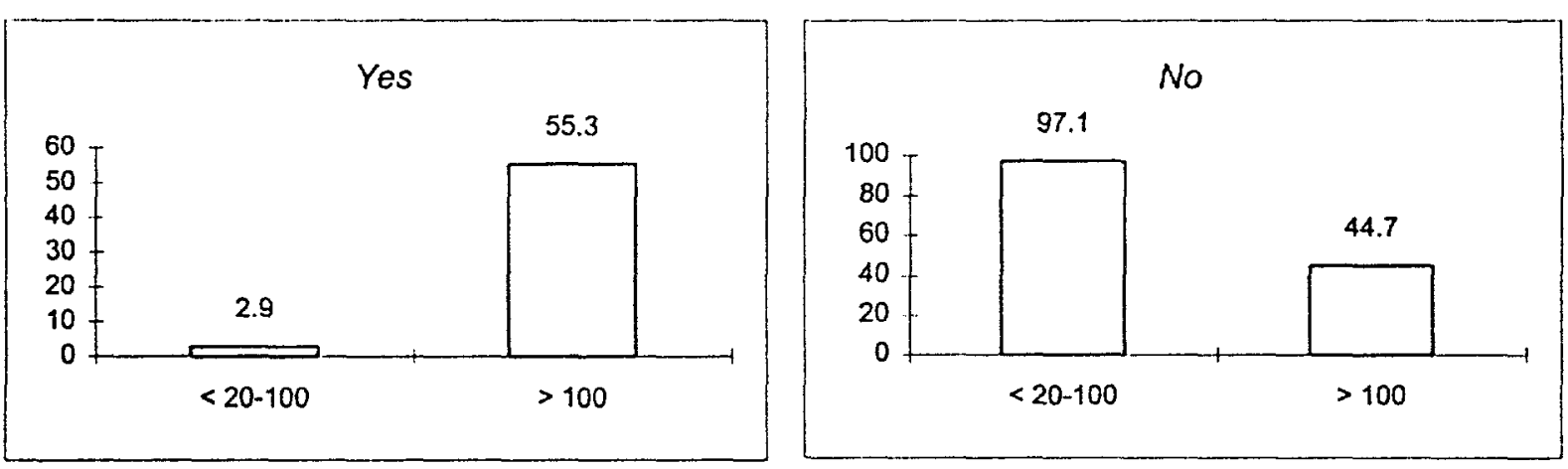
DOCTOR

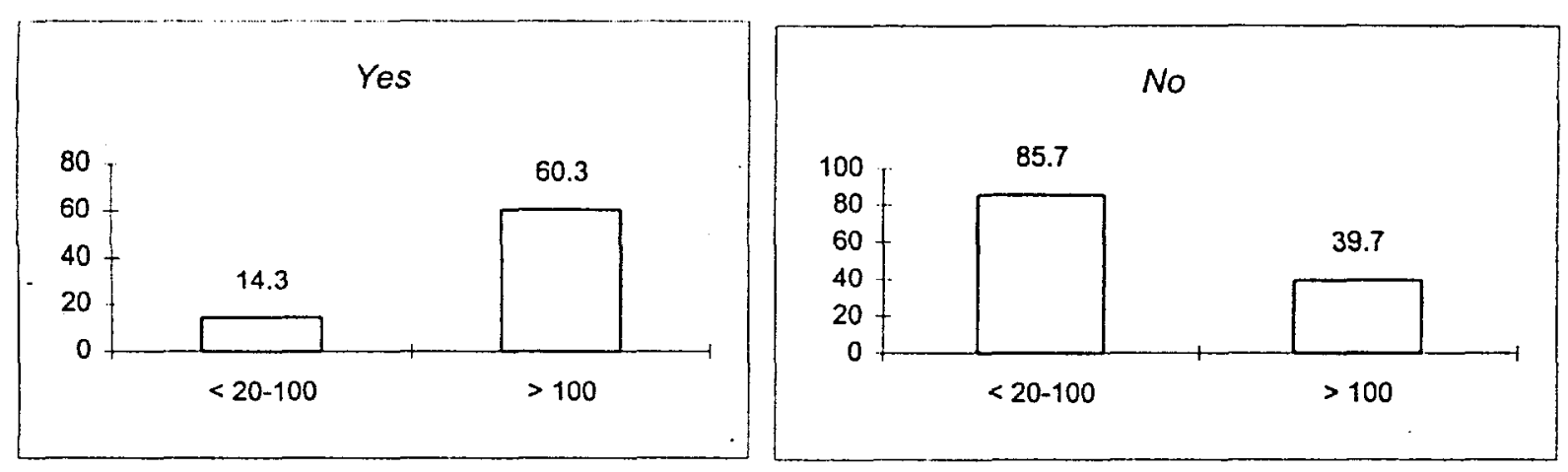




\section{KNOWLEDGE OF LEGAL WORKING CONDITIONS, WAGES AND BENEFITS}

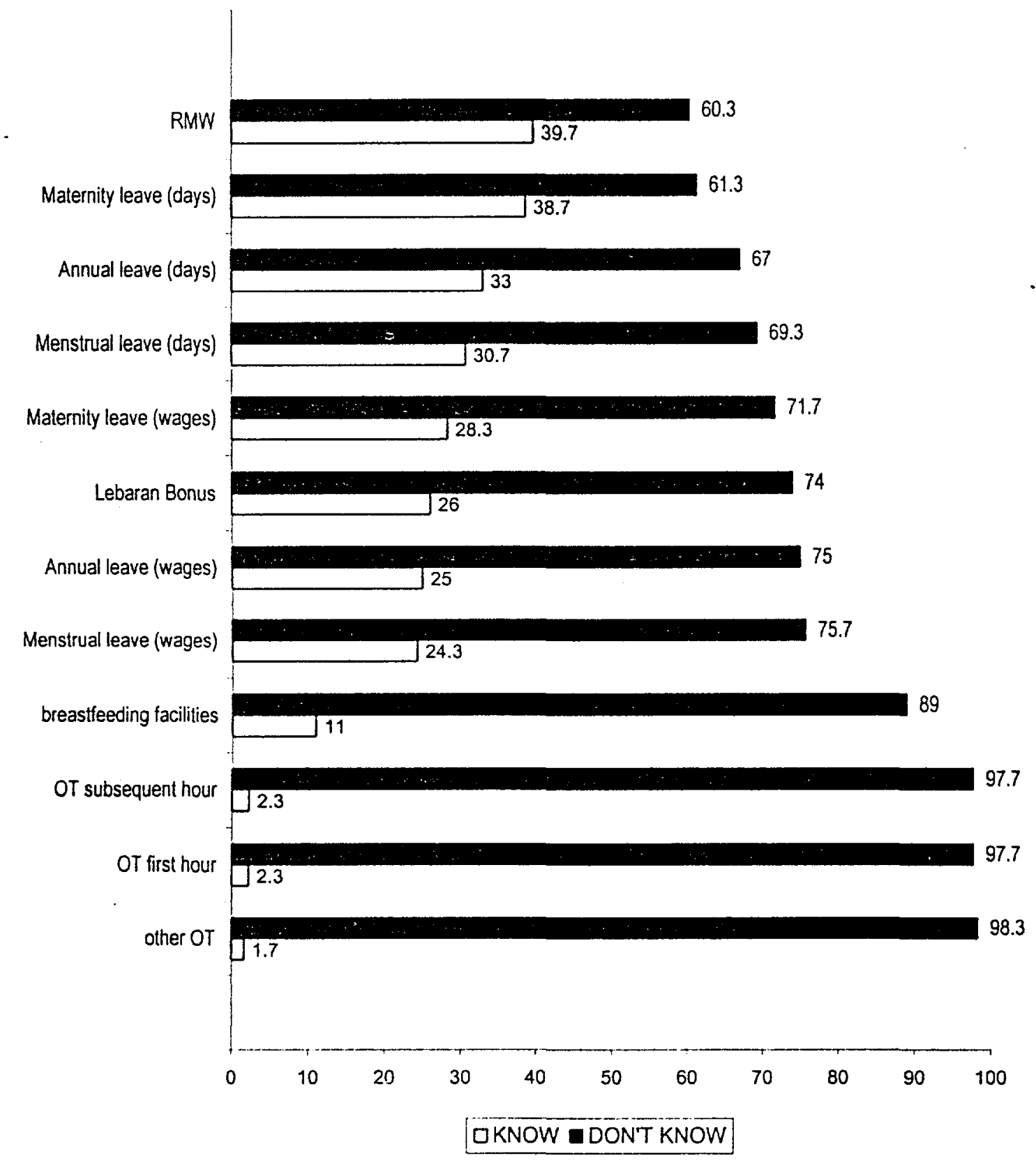




\section{SURVEY OF WOMEN WORKERS : QUESTIONNAIRE}

IDENTITY

\section{FIRM INFORMATION}

\begin{tabular}{|c|c|c|c|}
\hline NO. & QUESTIONS & CODE & GOTO \\
\hline 101 & Which firm do you work for? & confidential & \\
\hline 102 & What does this company produce? & 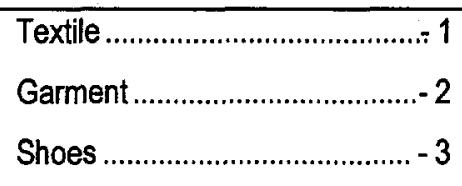 & \\
\hline 103 & How many workers does the firm employ? & 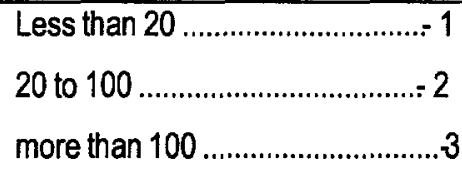 & \\
\hline 104 & Where is the factory that you work located? & KABUPATEN & \\
\hline
\end{tabular}




\section{WORKER INFORMATION}

\begin{tabular}{|c|c|c|c|}
\hline NO. & QUESTIONS & $\overline{C O D E}$ & GOTO \\
\hline $\begin{array}{r}201 \\
a\end{array}$ & $\begin{array}{l}\text { What is your occupation? } \\
\text { Textile: }\end{array}$ & 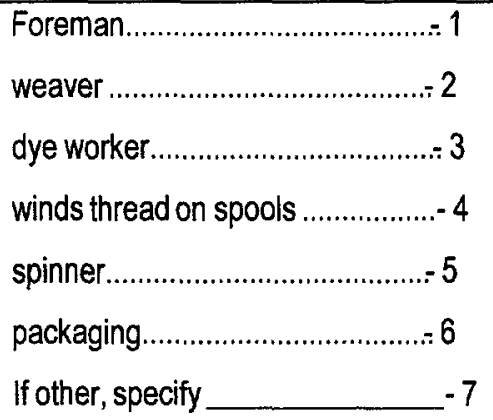 & \\
\hline $\begin{array}{c}201 \\
b\end{array}$ & Garment & 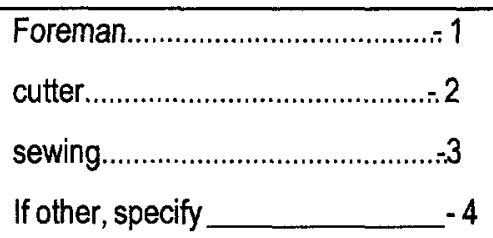 & \\
\hline $\begin{array}{c}201 \\
c\end{array}$ & Shoes & 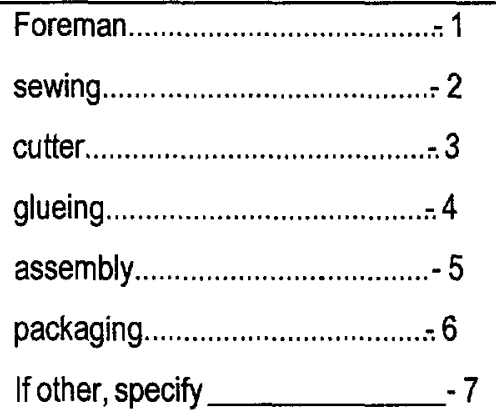 & \\
\hline 202 & How long have you worked with this firm? & $\begin{array}{l}\text { Less than } 3 \text { months ....................... } 1 \\
3 \text { to } 12 \text { months ............................. } 2 \\
1 \text { to } 3 \text { years............................... } 3 \\
\text { more than } 3 \text { years, specify______. } 4\end{array}$ & \\
\hline 203 & $\begin{array}{l}\text { How many years of total work experience do you } \\
\text { have? }\end{array}$ & $\begin{array}{l}\text { Less than } 1 \text { year ............................. } 1 \\
1 \text { to } 3 \text { years.................................... } 2 \\
3 \text { years or more, specify ___ }-3\end{array}$ & \\
\hline 204 & $\begin{array}{l}\text { How many years of experience do you have working } \\
\text { in this type of job? }\end{array}$ & $\begin{array}{l}\text { Less than } 1 \text { year ............................ } 1 \\
1 \text { to } 3 \text { years.................................... } 2 \\
3 \text { years or more, specify ______ }-3\end{array}$ & \\
\hline
\end{tabular}




\section{PERSONALINFORMATION}

\begin{tabular}{|c|c|c|c|}
\hline NO. & QUESTIONS & CODE & GOTO \\
\hline 301 & What is your age? & years & \\
\hline 302 & What level of education have you completed? & 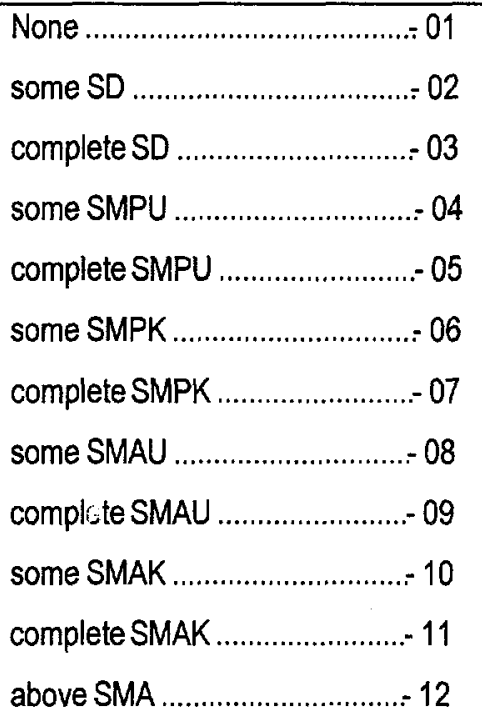 & \\
\hline 303 & What is your marital status? & $\begin{array}{l}\text { Single ....................................... } 1 \\
\text { married to someone from same area } \\
\text { or (hometown) ........................ } 2 \\
\text { married to someone from different } \\
\text { area (hometown) }\end{array}$ & $\rightarrow 307$ \\
\hline 304 & If you are married, where does your husband stay? & $\begin{array}{l}\text { With you .................................... } 1 \\
\text { another location .......................... } 2\end{array}$ & \\
\hline 305 & How many children do you have? & _ & \\
\hline 306 & Where do your children stay? & $\begin{array}{l}\text { with you ………......................... } 1 \\
\text { with your parents ........................... }-2 \\
\text { If other, specify }\end{array}$ & \\
\hline
\end{tabular}




\begin{tabular}{|c|l|l|l|}
\hline 307 & $\begin{array}{l}\text { If you are single, will your employer require you to } \\
\text { leave your job if you get married? }\end{array}$ & $\begin{array}{l}\text { Yes ....................................... } 1 \\
\text { No ....................................... } 2\end{array}$ & \\
\hline
\end{tabular}

\section{MIGRATION}

\begin{tabular}{|c|c|c|c|}
\hline NO. & QUESTIONS & CODE & GOTO \\
\hline 401 & Where do you stay? & 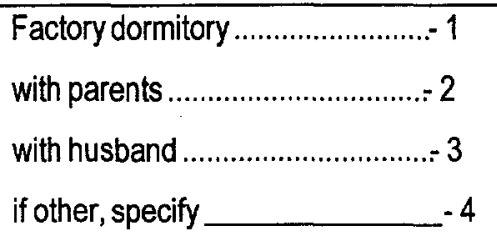 & $\begin{array}{l}\rightarrow 501 \\
\rightarrow 403 \\
\rightarrow 403\end{array}$ \\
\hline 402 & If you stay in a dormitory is it & 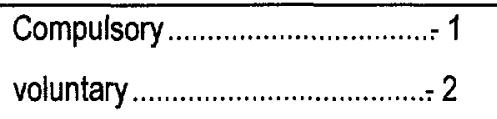 & \\
\hline 403 & Where do your parents stay? & KABUPATEN & \\
\hline 404 & Is your parents' home in & Desa .................................. & \\
\hline 405 & Do you receive financial support from your family? & Yes ………………………..... 1 & $\rightarrow 407$ \\
\hline 406 & $\begin{array}{c}\text { If yes, how much last month? or } \\
\text { last year? }\end{array}$ & $\begin{array}{l}\mathrm{Rp} \\
\mathrm{Rp} \\
\end{array}$ & \\
\hline 407 & $\begin{array}{l}\text { Do you receive any other material support from your } \\
\text { family? }\end{array}$ & $\begin{array}{l}\text { Rice } \\
\text { Any other sort kind of dish ............................................. } 1 \\
\text { clothes ................................... } 3 \\
\text { If other, specify }\end{array}$ & \\
\hline 408 & Do you ever send or bring money to your parents? & Yes ……........................... 1 & \\
\hline
\end{tabular}




\begin{tabular}{|c|c|c|}
\hline & & 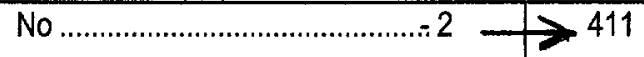 \\
\hline 409 & $\begin{array}{l}\text { How much did you send to your parents } \\
\qquad \text { in the last month, or } \\
\text { Last year }\end{array}$ & $\begin{array}{l}\mathrm{Rp} \\
\mathrm{Rp} \\
\end{array}$ \\
\hline
\end{tabular}

\begin{tabular}{|c|c|c|c|}
\hline NO. & QUESTIONS & CODE & GOTO \\
\hline 410 & $\begin{array}{l}\text { If you send or bring money home to your parents, } \\
\text { what do they usually spend it on? }\end{array}$ & $\begin{array}{lcc} & \text { Yes } & \text { No } \\
\text { Food ................................1 } & 2 \\
\text { any other goods................... } & 2 \\
\text { house building/renovation.....1 } & 2 \\
\text { ceremonies........................1 } & 2 \\
\text { If other, specify } & 1 & 2\end{array}$ & \\
\hline 411 & How often do you visit your family home? & 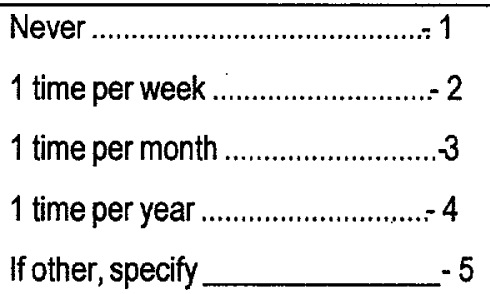 & \\
\hline 412 & $\begin{array}{l}\text { Do you plan to return to live in the place where your } \\
\text { parents live? }\end{array}$ & 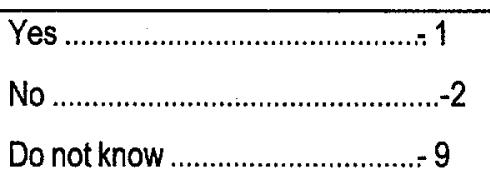 & $\begin{array}{l}\rightarrow 501 \\
\rightarrow 501\end{array}$ \\
\hline 413 & $\begin{array}{l}\text { In approximatelyhow many years will you return to } \\
\text { the place where your parents live? }\end{array}$ & 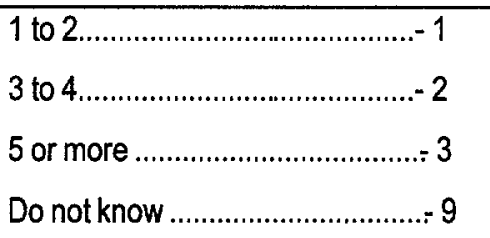 & \\
\hline
\end{tabular}

\section{WORKING CONDITIONSAND BENEFITS}

\begin{tabular}{|c|l|c|c|}
\hline NO. & \multicolumn{1}{|c|}{ QUESTIONS } & CODE & GO TO \\
\hline 501 & What is your work status? & Trainee/probationaryworker .........-1 & \\
\hline
\end{tabular}




\begin{tabular}{|l|l|c|c|}
\hline & & $\begin{array}{l}\text { permanentworker ........................ 2 } \\
\text { temporary worker .........................-3 } \\
\text { contract worker, how long___ } \\
\text { If other, specify }\end{array}$ & \\
\hline 502 & How many hours do you work per day? & hours & \\
\hline 503 & How many days per week do you work ? & days & \\
\hline 504 & How many months per year do you work? & months & \\
\hline
\end{tabular}

\begin{tabular}{|c|c|c|c|}
\hline NO. & QUESTIONS & CODE & GOTO \\
\hline \multirow[t]{3}{*}{505} & \multicolumn{3}{|c|}{ Please explain the salary and allowances your receive as follows: } \\
\hline & PayPeriod Wage Food allowances Transportat & 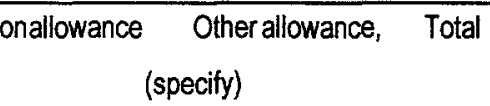 & \\
\hline & $\begin{array}{l}\text { Daily } \\
\text { Weekly } \\
\text { Monthly }\end{array}$ & & \\
\hline 506 & $\begin{array}{l}\text { What is the legal regional minimum wage? } \\
\text { (check only respondent's answer, do not present the } \\
\text { options). }\end{array}$ & 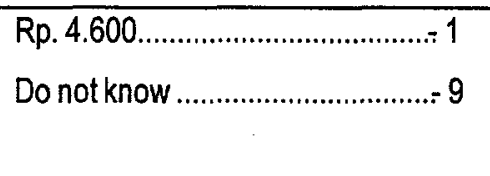 & \\
\hline 507 & $\begin{array}{l}\text { From the salary and allowances you receive are you } \\
\text { able to save funds? }\end{array}$ & 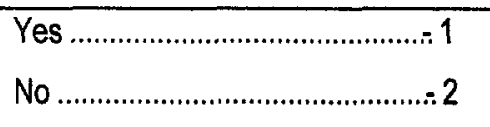 & $\Varangle 09$ \\
\hline 508 & $\begin{array}{l}\text { if yes, how much do you save? } \\
\text { Last month, or } \\
\text { Last year }\end{array}$ & $\mathrm{Rp}$ & \\
\hline 509 & Do you work overtime? & Yes …................................... & $>511$ \\
\hline
\end{tabular}




\begin{tabular}{|c|c|c|}
\hline 510 & $\begin{array}{l}\text { How many hours of overtime do you usually work } \\
\text { per week? }\end{array}$ & $\begin{array}{l}\text { Less than } 6 \text { hours........................ } 1 \\
6 \text { to } 12 \text { hours ................................ } 2 \\
\text { more than } 12 \text { hours ........................ } 3\end{array}$ \\
\hline 511 & Is overtime compulsory at your work place? & 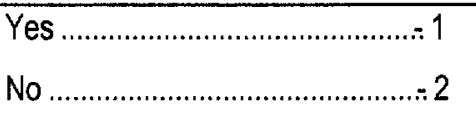 \\
\hline 512 & $\begin{array}{l}\text { What wages and allowance do you receive for } \\
\text { overtime work? } \\
\qquad \begin{array}{r}\text { Wage per hour firsthour } \\
\text { wage for subsequenthours } \\
\text { transportallowance } \\
\text { Do not know }\end{array}\end{array}$ & $\begin{array}{l}\mathrm{Rp}_{\square} \\
\mathrm{Rp} \_ \\
\mathrm{Rp} \\
\mathrm{Rp}\end{array}$ \\
\hline
\end{tabular}

\begin{tabular}{|c|c|c|c|}
\hline NO. & QUESTIONS & CODE & GOTO \\
\hline 513 & $\begin{array}{l}\text { What wages and benefits are women workers legally } \\
\text { entitled to receive, if they are asked to work } \\
\text { overtime? (check only respondent'sanswer, do not } \\
\text { present the options) }\end{array}$ & $\begin{array}{l}\text { KNOW DONT KNOW } \\
\text { First hour, standard } \\
\text { hourly wage } x 1,5 \ldots . . .1 \\
\text { subsequenthours } \\
\text { standard hourly } \\
\text { wage } x 2 \ldots \ldots \ldots \ldots \ldots \ldots . .1 \\
\text { allowance and transport } \\
\text { allowance ................1 }\end{array}$ & \\
\hline 514 & What menstrual leave do you receive? & 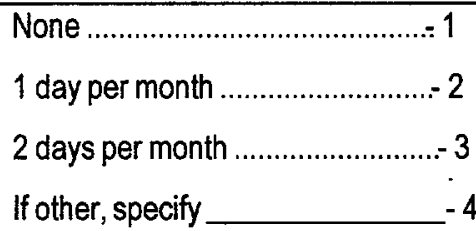 & \\
\hline 515 & $\begin{array}{l}\text { What menstrual leave are women workers legally } \\
\text { entitled to receive? (check only respondent'sanswer, } \\
\text { do not present the options) }\end{array}$ & $\begin{array}{l}\text { up to } 2 \text { days per month ...................-1 } \\
\text { Do not know } \ldots \ldots \ldots \ldots \ldots \ldots \ldots \ldots \ldots \ldots \ldots . . . . .\end{array}$ & \\
\hline 516 & $\begin{array}{l}\text { Do you receive your wages for your days of } \\
\text { menstrual leave? }\end{array}$ & Yes …………....................... & \\
\hline 517 & $\begin{array}{l}\text { What wages for menstrualleaves are women } \\
\text { workers legally entitled to receive? }\end{array}$ & $\begin{array}{l}\text { same wages } \ldots \ldots \ldots \ldots \ldots \ldots \ldots \ldots \ldots \ldots . . .1 \\
\text { Do not know ................................. } 9\end{array}$ & \\
\hline
\end{tabular}




\begin{tabular}{|c|c|c|c|}
\hline 518 & $\begin{array}{l}\text { Have you given birth to a child during the time that } \\
\text { you have been employed by this firm? }\end{array}$ & Yes ..................................... 1 & $\rightarrow 522$ \\
\hline 519 & $\begin{array}{l}\text { What maternityleave did you receive for the birth of } \\
\text { your most recent child? }\end{array}$ & $\begin{array}{l}\text { Less than one week ...................... } 1 \\
1 \text { to } 4 \text { weeks ................................ } 2 \\
5 \text { to } 8 \text { weeks .............................. } 3 \\
9 \text { to } 12 \text { weeks .......................... } 4 \\
\text { more than } 12 \text { weeks ....................... } 5\end{array}$ & \\
\hline 520 & $\begin{array}{l}\text { What maternityleave are women workers legally } \\
\text { entitled to receive? (check only respondent'sanswer, } \\
\text { do not present the options) }\end{array}$ & $\begin{array}{l}1.5 \text { months before and } 1.5 \text { months } \\
\text { after birth } \\
\text { if other, specify } \\
\text { Do not know ........................................... } 9\end{array}$ & \\
\hline 521 & $\begin{array}{l}\text { Did you receive your wages when you took your } \\
\text { most recent maternityleave? }\end{array}$ & Yes .................................... & \\
\hline 522 & $\begin{array}{l}\text { What wages are women workers legally entitled to } \\
\text { receive for maternityleave? (check only } \\
\text { respondent'sanswer, do not present the options) }\end{array}$ & $\begin{array}{l}\text { same wages as when working .......-1 } \\
\text { Do not know .................................. } 9\end{array}$ & \\
\hline
\end{tabular}

\begin{tabular}{|c|c|c|c|}
\hline NO. & QUESTIONS & CODE & GOTO \\
\hline 523 & $\begin{array}{l}\text { Does your employer provide breast feeding time or } \\
\text { facilities for women who are currently breast feeding } \\
\text { their babies? }\end{array}$ & 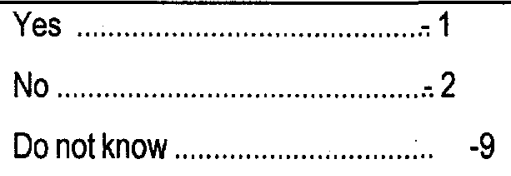 & \\
\hline 524 & $\begin{array}{l}\text { What breast feeding time or facilities are employers } \\
\text { legally required to provide for women workers? } \\
\text { (check only respondent's answer, do not present the } \\
\text { options) }\end{array}$ & $\begin{array}{l}\text { a clean quiet place where women can } \\
\text { breast feed, or up to two hours per day } \\
\text { off, in order to go home and breast } \\
\text { feed their baby } \\
\text { Do not know..........- } 1\end{array}$ & \\
\hline 525 & Do you have any form of health insurance? & 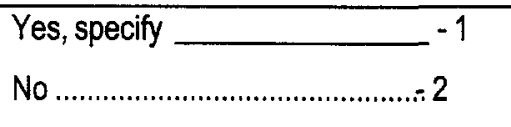 & \\
\hline 526 & $\begin{array}{l}\text { Are you included in the social security system } \\
\text { provided by the JAMSOSTEK (ASTEK) scheme? }\end{array}$ & 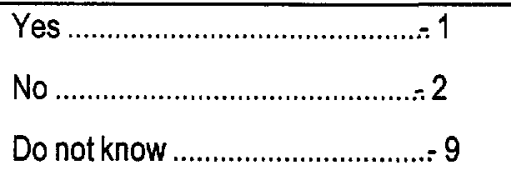 & \\
\hline 527 & How many days of annual leave do you receive? & $\begin{array}{l}\text { days or less ................................ } 1 \\
8 \text { to } 14 \text { days ................................. } 2 \\
\text { more than } 14 \text { days } \ldots \ldots \ldots \ldots \ldots \ldots \ldots \ldots . . . .3 \\
\text { If other, specify }\end{array}$ & \\
\hline
\end{tabular}




\begin{tabular}{|c|c|c|c|}
\hline 528 & $\begin{array}{l}\text { How much annual leave are workers legally entitled } \\
\text { to receive? (check only respondent'sanswer, do not } \\
\text { present the options) }\end{array}$ & $\begin{array}{l}\text { After } 1 \text { year work, } 12 \text { days vacation.... - } 1 \\
\text { Do not know ................................. } 9\end{array}$ & \\
\hline 529 & $\begin{array}{l}\text { Do you receive your wages for the period of your } \\
\text { annual leave? }\end{array}$ & 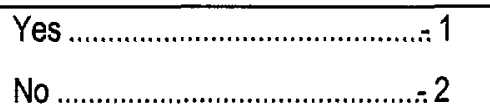 & \\
\hline 530 & $\begin{array}{l}\text { What wages for annual leave are workers legally } \\
\text { entitled to receive? (check only respondent'sanswer, } \\
\text { do not present the options) }\end{array}$ & $\begin{array}{l}12 \text { days paid vacation ..................... } 1 \\
\text { Do not know .................................. } 9\end{array}$ & \\
\hline 531 & What Lebaran bonus do you receive? & 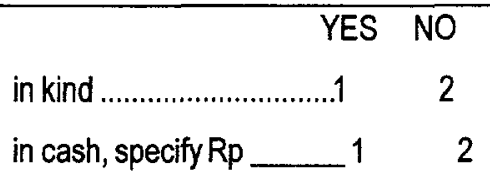 & \\
\hline 532 & $\begin{array}{l}\text { What Lebaran bonus are workers legally entitled to } \\
\text { receive? (check only respondent's answer, do not } \\
\text { present the options) }\end{array}$ & $\begin{array}{l}\text { one salary or equivalent.................-1 } \\
\text { Do not know ................................. } 9\end{array}$ & \\
\hline 533 & Are there daily production quotas set to your work? & Yes .................................... 1 & $\rightarrow 601$ \\
\hline 534 & Are you usually able to meet your production quota? & Yes ...................................... & \\
\hline
\end{tabular}

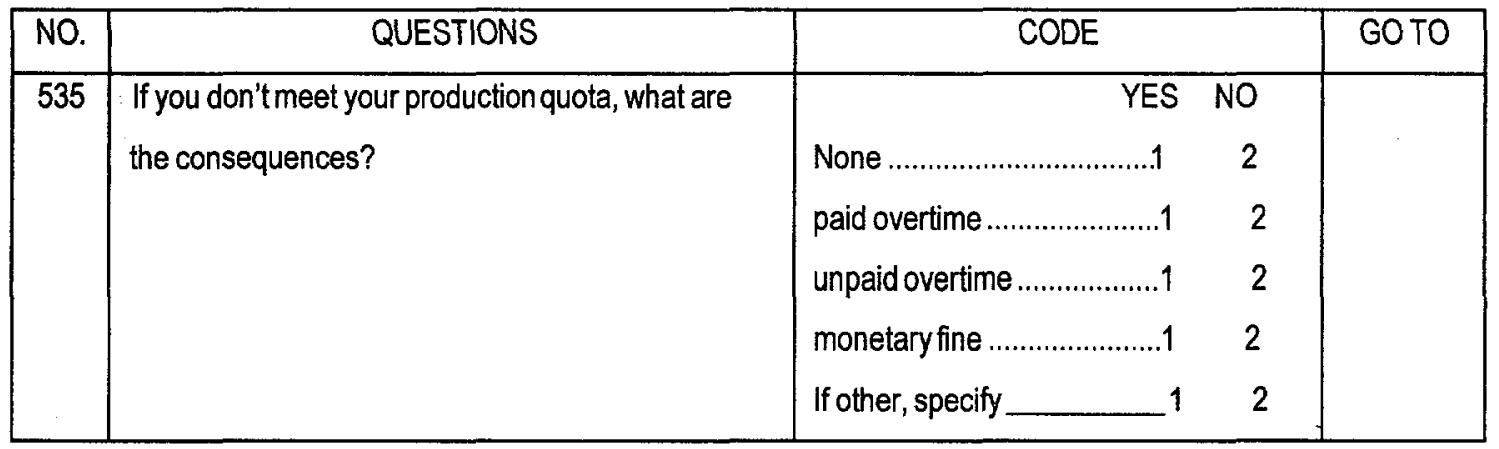

\section{HEALTH AND SAFETY}

\begin{tabular}{|c|c|c|c|}
\hline NO. & QUESTIONS & CODE & GOTO \\
\hline 601 & $\begin{array}{l}\text { Have you had any instruction or training on fire } \\
\text { safety? (equipment, procedures; exits) }\end{array}$ & 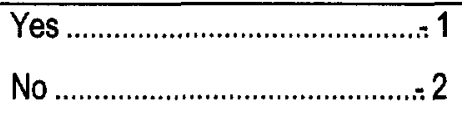 & \\
\hline 602 & Have you received any safety training regarding the & Yes ......................................... 1 & \\
\hline
\end{tabular}




\begin{tabular}{|c|c|c|c|}
\hline & equipmentand materials you use in your work? & 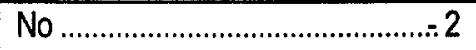 & \\
\hline 603 & $\begin{array}{l}\text { Is there any adequate clean drinking water in your } \\
\text { work place? }\end{array}$ & Yes ....................................... & \\
\hline 604 & $\begin{array}{l}\text { Are there any adequate clean WC facilities at your } \\
\text { work place? }\end{array}$ & Yes ...................................... 1 & \\
\hline 605 & $\begin{array}{l}\text { What type of safety equipment or safety tools do you } \\
\text { think are needed for your job and you would like your } \\
\text { employer to provide for you? }\end{array}$ & 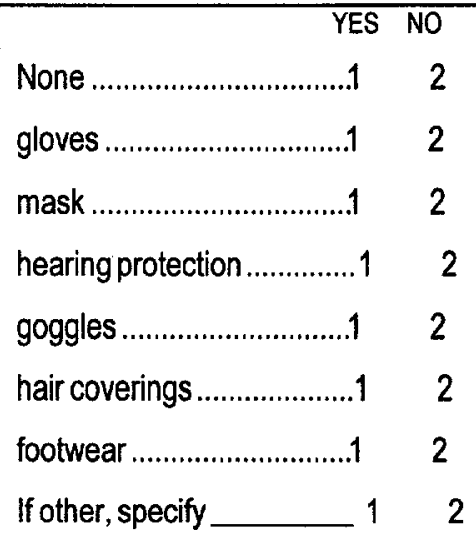 & \\
\hline 606 & $\begin{array}{l}\text { Have you been provided with safety equipmentor } \\
\text { safety tools to protect your health in your work } \\
\text { place? }\end{array}$ & 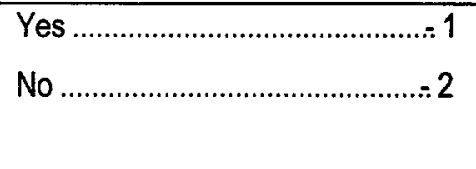 & $\Rightarrow 610$ \\
\hline
\end{tabular}

\begin{tabular}{|c|c|c|c|c|}
\hline NO. & QUESTIONS & \multicolumn{2}{|l|}{ CODE } & GOTO \\
\hline 607 & $\begin{array}{l}\text { What types safety equipment tools have been } \\
\text { provided to you? }\end{array}$ & 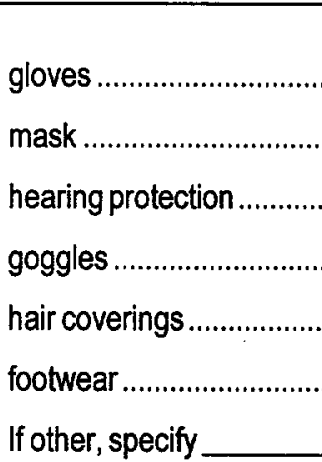 & $\begin{array}{c}\text { NO } \\
2 \\
2 \\
2 \\
2 \\
2 \\
2 \\
2\end{array}$ & \\
\hline 608 & $\begin{array}{l}\text { Of the safety equipmentor tools provided, do you } \\
\text { use them? }\end{array}$ & $\begin{array}{l}\text { YES NO } \\
\text { gloves .....................1 } \\
\text { mask ........................1 } \\
\text { hearing protection.......1 } \\
\text { goggles....................1 } \\
\text { hair coverings............1 }\end{array}$ & $\begin{array}{l}\text { TTMES } \\
3 \\
3 \\
3 \\
3 \\
3\end{array}$ & \\
\hline
\end{tabular}




\begin{tabular}{|c|c|c|c|}
\hline & & $\begin{array}{llll}\text { footwear ...................... } & 2 & 3 \\
\text { If other, specify __ } 1 & 2 & 3\end{array}$ & \\
\hline 609 & $\begin{array}{l}\text { If you don't use the safety equipmentor tools } \\
\text { provided, why not? }\end{array}$ & $\begin{array}{lrr} & \text { YES } & \text { NO } \\
\text { Not effective } \ldots \ldots \ldots \ldots \ldots \ldots \ldots \ldots \ldots . .1 & 2 \\
\text { Uncomfortable } \ldots \ldots \ldots \ldots \ldots \ldots \ldots . .1 & 2 \\
\text { prefer not to use ...................1 } & 2 \\
\text { If other, specify } & 1 & 2\end{array}$ & \\
\hline 610 & $\begin{array}{l}\text { What types of health problems are you having } \\
\text { currently of have had since you joined this job? }\end{array}$ & 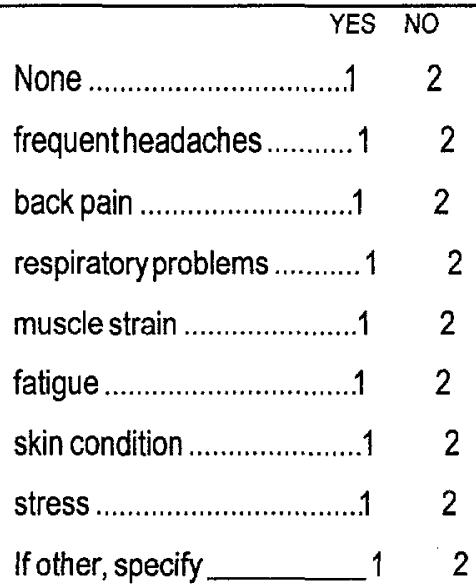 & \\
\hline 611 & $\begin{array}{l}\text { Do you think that any of the above problems related } \\
\text { to your work place of working conditions? }\end{array}$ & 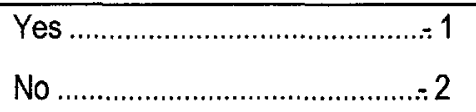 & \\
\hline 612 & Have you had any injuries at your work place? & Yes .................................... & $\rightarrow 614$ \\
\hline 613 & If yes, specify & & \\
\hline
\end{tabular}

\begin{tabular}{|c|c|c|c|}
\hline NO. & QUESTIONS & $\overline{C O D E}$ & GOTO \\
\hline 614 & $\begin{array}{l}\text { How many days of work did you miss due to these } \\
\text { health problems or injuries in the past year? }\end{array}$ & $\begin{array}{l}\text { None } \\
\text { less than } 5 \text { days ................................................... } 2 \\
5 \text { to } 8 \text { days } \\
9 \text { days or more }\end{array}$ & \\
\hline 615 & Does your employer provide first aid services? & 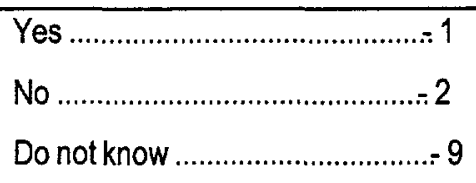 & \\
\hline 616 & $\begin{array}{l}\text { Does the enterprise where you work have a clinic, } \\
\text { nurse, or a doctor available on the premise? }\end{array}$ & $\begin{array}{lcc} & \text { YES } & \text { NO } \\
\text { Clinic } \ldots \ldots \ldots \ldots \ldots \ldots \ldots \ldots \ldots \ldots . .1 & 2 \\
\text { nurse } \ldots \ldots \ldots \ldots \ldots \ldots \ldots \ldots \ldots \ldots \ldots \ldots & \\
\end{array}$ & \\
\hline
\end{tabular}




\begin{tabular}{|c|c|c|}
\hline & & Doctor ................................ \\
\hline 617 & $\begin{array}{l}\text { Where do you normally go when you have health } \\
\text { problems? }\end{array}$ & 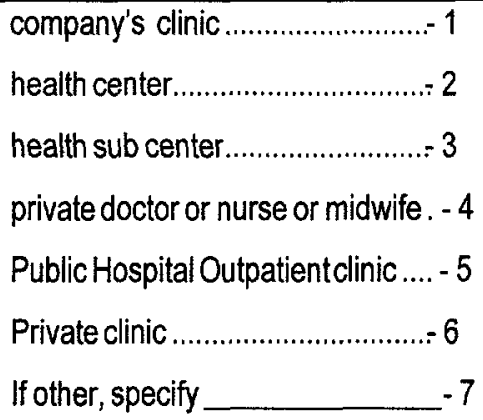 \\
\hline 618 & For each visit, how much do you normally pay? & 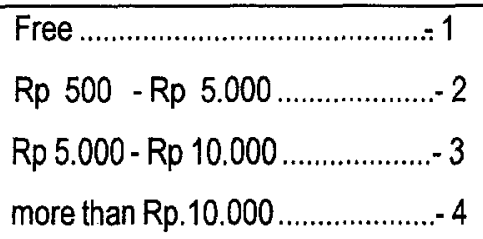 \\
\hline 619 & Have you ever heard of an illness called AIDS/HIV? & 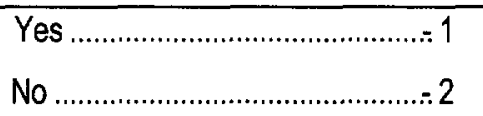 \\
\hline 620 & $\begin{array}{l}\text { Does the enterprise where you work offer any of the } \\
\text { following services: }\end{array}$ & 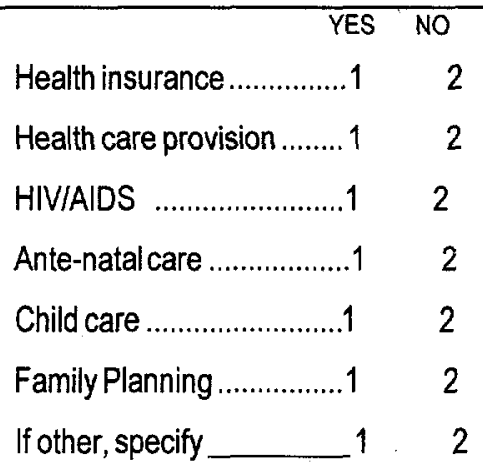 \\
\hline
\end{tabular}

\begin{tabular}{|c|c|c|c|c|}
\hline NO. & QUESTIONS & CODE & & GOTO \\
\hline 621 & $\begin{array}{l}\text { Would you like the enterprise where you work to } \\
\text { offer any of the following services: }\end{array}$ & $\begin{array}{l}\text { Health insurance ............... } \\
\text { Health care provision ........ } 1 \\
\text { HIVIAIDS .....................1 } \\
\text { Ante-natal care }\end{array}$ & $\begin{array}{l}\text { NO } \\
2 \\
2 \\
2 \\
2 \\
2 \\
2 \\
2\end{array}$ & \\
\hline
\end{tabular}



place who experienced sexual harassment?

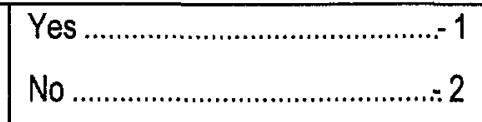

\begin{tabular}{|c|c|c|c|}
\hline \multicolumn{4}{|c|}{ 7. UNIONS } \\
\hline NO. & QUESTIONS & CODE & GOTO \\
\hline 701 & Do you belong to any workers organizations? & Yes …................................ & \\
\hline 702 & Is there any SPSI unit in your work place? & 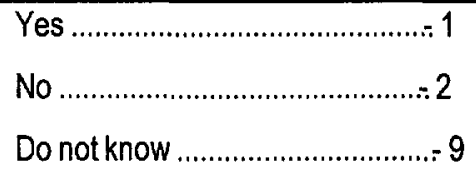 & $\begin{array}{l}\rightarrow 705 \\
\rightarrow 705\end{array}$ \\
\hline 703 & Are you a member of SPSI? & Yes .................................... & \\
\hline 704 & $\begin{array}{l}\text { Due to the SPSI are your working conditions, wage } \\
\text { and benefits }\end{array}$ & better & \\
\hline 705 & $\begin{array}{l}\text { Do you have a Collective Labor Agreement with your } \\
\text { employer? }\end{array}$ & 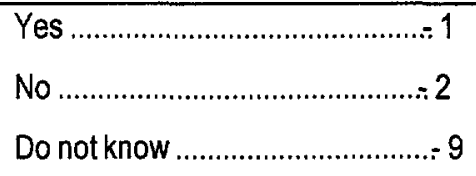 & $\begin{array}{l}\rightarrow 708 \\
\rightarrow 708\end{array}$ \\
\hline 706 & $\begin{array}{l}\text { Are you familiar with the contents of the collective } \\
\text { agreement? }\end{array}$ & 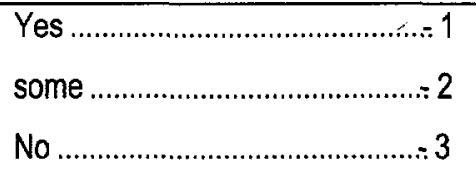 & \\
\hline 707 & $\begin{array}{l}\text { What improvementsin your working conditions have } \\
\text { there been due to the Collective Labor Agreement? }\end{array}$ & 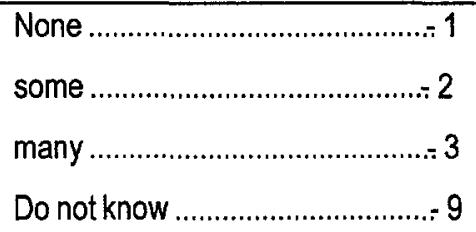 & \\
\hline
\end{tabular}

\begin{tabular}{|c|c|c|c|}
\hline NO. & QUESTIONS & CODE & GOTO \\
\hline 708 & $\begin{array}{l}\text { Compared with other workers you know in the same } \\
\text { region, is your situation: }\end{array}$ & 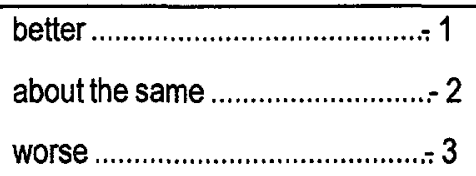 & \\
\hline 709 & $\begin{array}{l}\text { If you think about your life two years ago, is your } \\
\text { situation now: }\end{array}$ & better & \\
\hline
\end{tabular}




\section{Policy Research Working Paper Series}

Title

WPS1732 Agricultural Trade and Rural Development in the Middle East and North Africa: Recent Developments and Prospects

WPS1733 The Usefulness of Private and Public Yuko Konoshita Information for Foreign Investment Ashoka Mody Decisions

WPS1734 Are Markets Learning? Behavior in the Secondary Market for Brady Bonds

WPS1735 Competition Policy and the Global Bernard Hoekman Trading System: A Developing-Country Perspective

WPS1736 Creating Incentives for Private Infrastructure Companies to Become Colin Mayer More Efficient

WPS1737 Ownership and Corporate Governance: Evidence from the Czech Republic

WPS1738 Some Aspects of Poverty in Sri Lanka: 1985-90

WPS1739 Safe and Sound Banking in Developing Countries: We're Not in Kansas Anymore

WPS1740 When is Foreign Aid Policy Credible? Jakob Svensson Aid Dependence and Conditionality

WPS1741 Privatization, Public Investment, and Harry Huizinga Capital Income Taxation

WPS1742 Transport Costs and "Natural" Integration in Mercosur

WPS1743 How China's Government and State Enterprises Partitioned Property and Control Rights

WPS1744 Moving to Greener Pastures? Multinationals and the Pollutionhaven Hypothesis
Luca Barbone Ian Alexander

Stijn Claessens Simeon Djankov Gernard Pohl

Gaurav Datt

Dileni Gunewardena Søren Bo Nielsen

Azita Amjadi

L. Alan Winters

Date

February 1997

February 1997

February 1997

March 1997

March 1997

March 1997

March 1997

March 1997

March 1997

March 1997

March 1997

March 1997

Lixin Colin Xu

Gunnar S. Eskeland Ann E. Harrison
March 1997

March 1997
Contact for paper

J. Ngaine 37959

R. Reff 34815

L. Barbone 32556

J. Ngaine 37949

R. Schneiderman 30191

F. Hatab 35835

\section{A. Ramirez} 85734

B. Moore 38526

R. Martin 39026

P. Sintim-Aboagye 38526

J. Ngaine 37947

P. Sintim-Aboagye 37644

C. Bernardo 31148

J. Ngaine 37947 
Policy Research Working Paper Series

The

WPS 1746 The Role of Long-Term Finance: Theory and Evidence

WPS1747 Protection and Trade in Services: A Survey

WPS1748 Has Agricultural Trade Liberalization Merlinda D. Ingco Improved Welfare in the Least-Developed Countries? Yes

WPS1749 Applying Economic Analysis to Technical Assistance Projects

WPS1750 Regional Integration and Foreign Direet Invesiment: A Conceptual Framework and Three Cases

WPS1751 Using Tariff Indices to Evaluate Preferential Trading Arrangements: An Application to Chile

WPS1752 Ghana's Labor Market (1987-92)

WPS1753 Can Capital Markets Create Incentives for Pollution Control?

WPS 1754 Research on Land Markets in South Asia: What Have We Learned?

WPS1755 Survey Responses from Women Workers in Indonesia's Textile, Garment, and Footwear Industries
Author

Gerard Caprio, Jr.

Asli Demirgüç-Kunt

Bernard Hoekman

Carlos A. Primo Braga

April 1997

April 1987

April 1997

Gary McMahon

Magnus Blómstrom

Ari Kokko

Eric Bond

April 1997

April 1997

Sudharshan Canagarajah

Saji Thomas

Paul Lanoie

Benoit Laplante

Rashid Faruqee

Kevin Carey

Mari Pangestu

Medeiina K. Hendytio

April 1997

April 1997

Aprit 1997

April 1997
Contact

for paper

P. Sintim-Aboagye 38526

J. Ngaine

37947

J. Ngaine

37947

C. Bernardo 37699

J. Ngaine 37947

J. Ngaine 37947

B. Casely-Hayford 34672

R. Yazigi 37176

C. Anbiah 89275

J. israel

85117 